United States Department of Agriculture

Marketing and Regulatory Programs

Agricultural Marketing Service

Transportation and Marketing Program

August 2020

Author:

Delmy L. Salin, USDA, Agricultural Marketing Service

Graphic Designer:

Jessica E. Ladd, USDA, Agricultural Marketing Service

\section{Preferred Citation}

Salin, Delmy. Soybean Transportation Guide: Brazil 2019. August 2020. U.S. Dept. of Agriculture, Agricultural Marketing Service. Web. <http://dx.doi.org/10.9752/TS048.08-2020>

USDA is an equal opportunity provider, employer, and lender. 


\section{CONTENTS}

Soybean Transportation Guide: Brazil $2019 \ldots \ldots \ldots \ldots \ldots \ldots \ldots \ldots \ldots \ldots$. . . . . . . . 4

General Information $\ldots \ldots \ldots \ldots \ldots \ldots \ldots \ldots \ldots \ldots \ldots \ldots \ldots \ldots \ldots \ldots \ldots \ldots \ldots \ldots$

2019 Summary . . . . . . . . . . . . . . . . 7

Transportation Infrastructure. ...................... 22

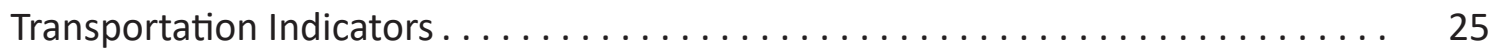

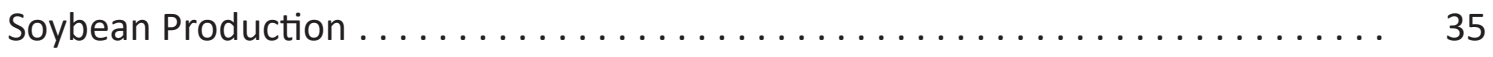

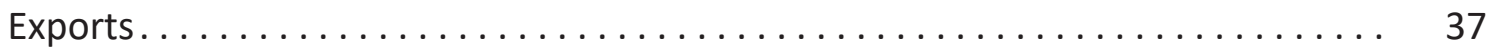

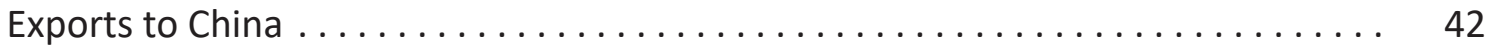

Transportation Modes .............................. 51

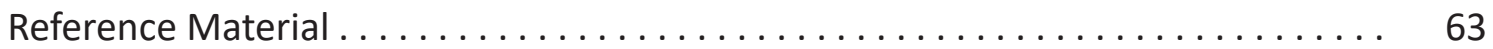

Photo Credits. ................................ 68 


\section{SOYBEAN TRANSPORTATION GUIDE: BRAZIL 2019}

\section{Executive Summary}

The Soybean Transportation Guide is a visual snapshot of Brazilian soybean transportation in 2019. It provides data on the cost of shipping soybeans, via highways and ocean, to Shanghai, China, and Hamburg, Germany. It also includes information about soybean production, exports, railways, ports, and infrastructural developments.

Brazil is one of the most important U.S. competitors in the world oilseed market. Brazil's competitiveness in the world market depends largely on continual improvement of its transportation infrastructure to reduce transportation costs. The country's position has also benefited from low production costs, increases in planted area, high productivity, and a weak national currency. Because Brazilian and U.S. producers use the same advanced production and technological methods, their soybeans are relatively interchangeable for buyers. U.S. soybean competitiveness worldwide rests on critical factors such as transportation costs and infrastructure improvements. Brazil is gaining a cost advantage. However, the United States retains a significant share of global soybean exports.

Since 2013, Brazil has surpassed U.S. soybean exports, becoming the top world soybean exporter. Further, USDA forecasts that Brazil is expected to be the world's largest soybean exporter through 2029. In recent years, the United States and Brazil have continued to vie for the position of the world's leading producer. The United States remains the second-largest exporter, followed by Argentina, Paraguay, and Canada. China is the driver of global soybean trade, accounting for more than half of soybean worldwide imports.

\section{Soybean Transportation Cost and Export Demand}

During 2019, Brazil exported 74.1 million metric tons (mmt) of soybeans, 11 percent less than 2018's total of $83.3 \mathrm{mmt}$ (fig. 1) - a decline that also reduced transportation demand. The cost of shipping a metric ton of soybeans 100 miles by truck decreased 15 percent from $\$ 8.44$ in 2018 to $\$ 7.19$ in 2019 . However, truck rates measured in reais (R\$) varied in comparison with their estimates in U.S. dollars, reflecting the depreciation of the Brazilian real (R\$) against the U.S. dollar. Truck rates also fluctuated because of the completion of the BR 163 road paving project, connecting Sorriso, North Mato Grosso, to Itaituba, Pará. For example, truck rates from Cruz Alta, Rio Grande do Sul to Rio Grande decreased 14 percent. Truck rates from Sorriso, North Mato Grosso, to the southern port of Santos and Paranaguá decreased 14-16 percent. Truck rates from North Mato Grosso to Rondonópolis (rail terminal) and to the northern river ports of Santarém and Itaituba/Miritituba (barge terminal) decreased 12-18 percent. Industry analysts expect transportation costs to reduce further, up to U.S. \$7/metric ton (mt) (or R\$30/mt) for the route from Sorriso to Itaituba. From 2018 to 2019, the Brazilian real depreciated nearly 7 percent against the U.S. dollar, from R\$3.69 per U.S. dollar to R\$3.94 per U.S. dollar. Ocean rates from the southern Brazilian ports to Shanghai, China, increased significantly during the second half of the year, averaging 9-11 percent higher than 2018 ocean freight costs. Ocean rates to Hamburg, Germany, varied, increasing from Santos and declining from Rio Grande and Paranaguá. Ocean rates increased because of higher bunker fuel prices, higher Brazilian corn exports, and a strong iron ore trade that reduced the availability of Panamax vessels for grain exports at the Brazilian ports.

From 2018 to 2019, Brazilian soybean transportation costs to Shanghai, China-as a percentage of total landed costs for the routes of North Mato Grosso to Santos and Santarém-slightly decreased in response to lower truck rates and farm prices. In Sorriso, North Mato Grosso-the largest Brazilian soybean-producing State-2019 transportation costs represented 28 percent of the total landed costs of shipping soybeans to Shanghai through Santos, compared with 34 percent in 2008 and 45 percent in 2006. Typically, Brazilian soybean exports peak in May and decline through the end of the year. Average Brazilian soybean export prices 
decreased nearly 12 percent, from $\$ 408$ per $\mathrm{mt}$ to $\$ 360$ per $\mathrm{mt}$, from the same time in 2018 . The weakening of the Brazilian real against the U.S. dollar partially offset the nearly 8 percent fall in farm gate prices, from $\$ 323.42 / \mathrm{mt}$ in 2018 to $\$ 297.97 / \mathrm{mt}$ in 2019 (Companhia Nacional de Abastecimento (CONAB)). Soybeans are priced in U.S. dollars but paid in reais. Farm prices measured in reais increased an average of 2.4 percent, from $\mathrm{R} \$ 1,148.12 / \mathrm{mt}$ in 2018 to $\mathrm{R} \$ 1,175.84$ in 2019 (CONAB).

Overall, Brazil's infrastructure is improving, narrowing the difference in shipping costs between Sorriso and lowa to Shanghai. During 2019, shipping soybeans by truck for the first leg, the route from Sorriso, North Mato Grosso, to Shanghai cost about \$22 per metric ton more than the route from the U.S. Gulf and Pacific Northwest (PNW) routes to Shanghai. However, the cost advantage to U.S. shippers narrowed to \$10 per metric ton when North Mato Grosso soybeans were shipped by rail to Santos for the first leg and to $\$ 9$ per metric ton when shipped by barge to Barcarena for the first leg. Soybean exports to China in 2019 declined nearly 16 percent to $58 \mathrm{mmt}$ (valued at $\$ 20.5$ billion) from $68.6 \mathrm{mmt}$ in 2018, because of an epidemic of African swine fever that reduced the country's hog herd. In 2019, China received 78 percent of Brazil's total soybean exports $(74 \mathrm{mmt}$ ). The next highest shares of Brazil's soybean exports went (in declining order) to Spain, the Netherlands, Thailand, and Iran. Of all the Brazilian States, Mato Grosso exported the most soybeans in 2019-roughly 21 percent of the national total-followed by Rio Grande do Sul, Paraná, Goiás, São Paulo, São Paulo, Minas Gerais, and Mato Grosso do Sul. Mato Grosso was also the top soybeans exporter to China.

In 2019, Santos was the largest Brazilian soybean export port, followed by Rio Grande, Paranaguá, São Luís, Barcarena, and São Francisco do Sul. These six ports accounted for 82 percent of Brazil's total exports. Looking at the split from a north/south perspective, the southern ports of Santos, Rio Grande, Paranaguá, and São Francisco do Sul dominate the soybean trade to China, accounting for about 72 percent of Brazil's soybean exports to China. Meanwhile, the northeastern ports of São Luís, Vitória, Salvador, and Barcarena accounted for nearly 26 percent of exports to China. The Amazon River ports of Manaus and Santarém exported nearly 2 percent to China.

During the 2019 peak harvest season, loading delays and vessel backups were similar in Brazilian ports and the U.S. Gulf, averaging 3-10 days - narrowing the time spread between the regions. Seasonally, the Northern ports had lower loading delays and vessel backups than the Southern ports of Santos and Paranaguá. Barcarena had vessel loading delays of 3-4 days, which nearly offset the roughly 3-day-longer voyage distance to Shanghai, compared with the ports of Santos and Paranaguá. In 2019, the ocean freight spread was about \$1-\$2/mt for route from the northeastern ports of Barcarena $(\$ 34.96 / \mathrm{mt})$ and São Luís $(\$ 34.81 / \mathrm{mt})$ to Shanghai and the route from the port of Santos $(\$ 33.65)$ to Shanghai. Ocean freight spread is the cost difference between two vessel routes to the same destination.

\section{Acknowledgments}

For data, regional information, and maps of Brazil, the author would like to thank the Associação Nacional dos Transportadores Ferroviários (ANTF), Escola Superior de Agricultura "Luiz de Queiroz" / Grupo de Pesquisa e Extensão em Logística Agroindustrial (ESALQ-LOG), the Assesoria de Comunicação dos Portos de Paranaguá e Antonina (ASSCOM-APPA), and USDA, Foreign Agricultural Service (FAS), Global Market Analysis (GMA). The author is, also, grateful for comments and critiques by Keith Menzie, Joanna Hitchner, and David Boussios (USDA, Office of the Chief Economist), Mark Ash (USDA, Economic Research Service), Katherine Woody (USDA, FAS, Agricultural Attaché, Brasilia), and Kranti Mulik (USDA, Agricultural Marketing Service (AMS)). Thanks, also, to USDA, AMS employees Maria Williams, editor, and Jessica Ladd, graphic designer. 


\section{GENERAL INFORMATION}

\section{BRAZIL}

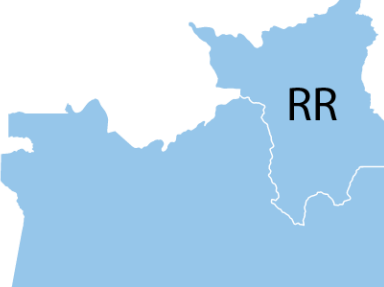

AM

AC

\section{State and Abbreviation}

\section{Acre (AC)}

Alagoas (AL)

Amapá (AP)

Amazonas (AM)

Bahia (BA)

Ceará (CE)

Distrito Federal (DF)

Espírito Santo (ES)

Goiás (GO)

Maranhão (MA)

Mato Grosso (MT)

Mato Grosso do Sul (MS)

Minas Gerais (MG)
Pará (PA)

Paraíba (PB)

Paraná (PR)

Pernambuco (PE)

Piauí (PI)

Rio de Janeiro (RJ)

Rio Grande do Sul (RS)

Rondônia (RO)

Roraima (RR)

Santa Catarina (SC)

São Paulo (SP)

Sergipe (SE)

Tocantins (TO)

\section{AP}

RO

PA

MA

PI

TO

MT

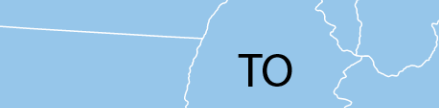

BA

CE

$\mathrm{RN}$

PB

$P E$

$A L$

DF

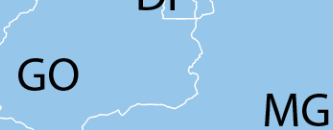

MS

ES

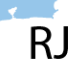

\section{Information about Brazil}

\begin{tabular}{|l|l|}
\hline Population: & $\begin{array}{l}211,257,586 \quad \text { (March 2020 estimate, Census, } \\
\text { Geografia e Estatística (IBGEE)) }\end{array}$ \\
\hline Gross Domestic Product per Capita, 2019: & US\$8,960 (International Monetary Fund) \\
\hline Inflation, 2019: & 3.91 percent (Banco Central do Brasil) \\
\hline Unemployment, 4th Quarter 2019: & 11 percent (IBGE) \\
\hline Area: & $8,515,770$ square kilometers \\
\hline Languages: & Portuguese (official), Spanish, English, French
\end{tabular}




\section{SUMMARY}

\section{Routes ${ }^{1}$ and regions considered in the Brazilian soybean export transportation indicator ${ }^{2}$}

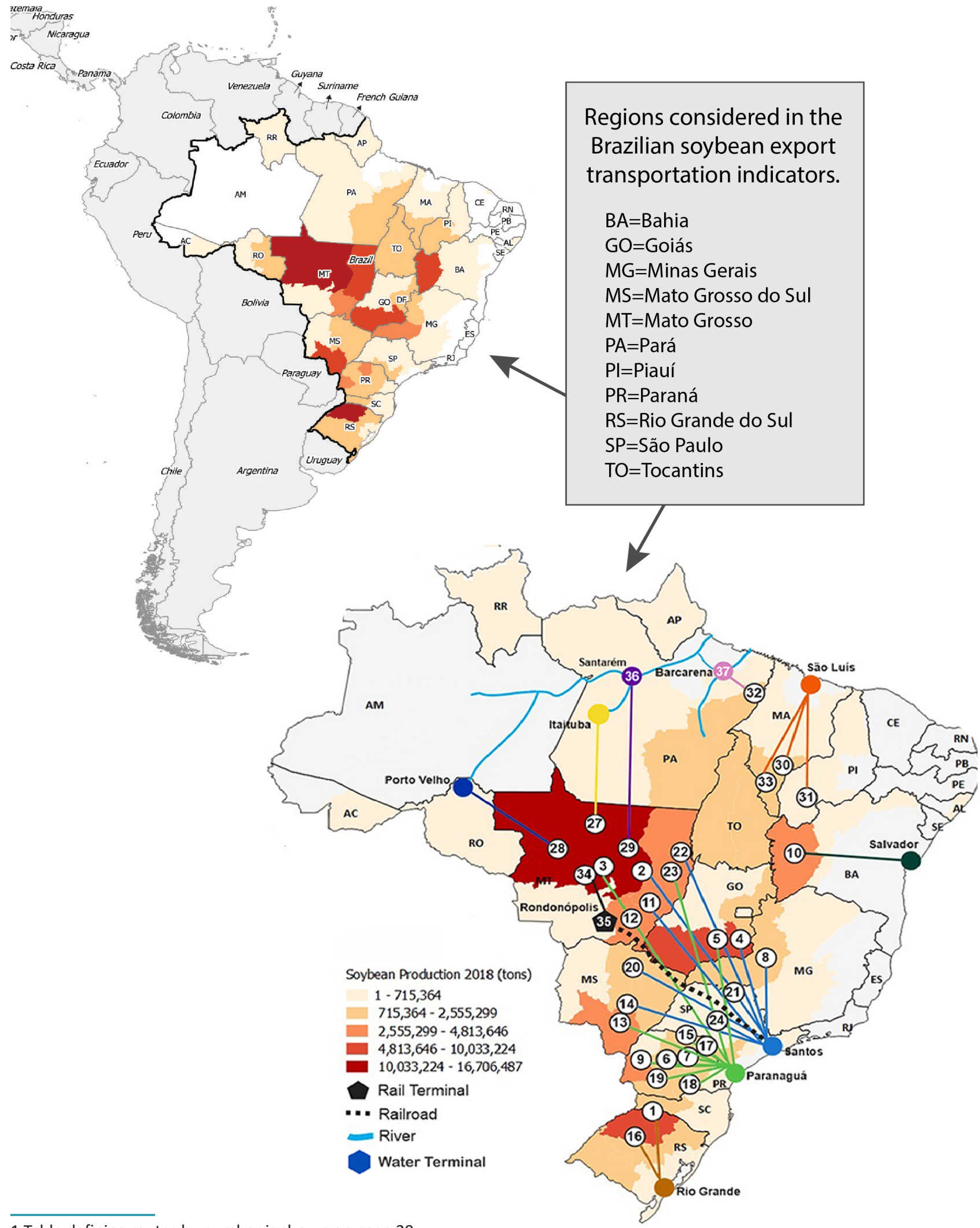

1 Table defining routes by number is shown on page 29.

2 Regions comprised about 81 percent of Brazilian soybean production, 2018.

Source: University of São Paulo, Escola Superior de Agricultura "Luiz de Queiroz," Brazil (ESALQ/USP) and USDA, Agricultural Marketing Service. 
In 2019, Brazilian soybean transportation costs to Shanghai, China-as a percentage of total landed costs for the routes of North Mato Grosso to Santos and Santarém - slightly decreased in response to lower truck rates and farm prices than in 2018. In Sorriso, North Mato Grosso-the largest Brazilian soybean-producing State-2019 transportation costs represented 28 percent of the total landed costs of shipping soybeans to Shanghai through Santos, compared with 34 percent in 2008 and 45 percent in 2006.

Costs of transporting Brazilian soybeans from the southern ports to Shanghai, China, 2014-19

\begin{tabular}{|c|c|c|c|c|c|c|c|c|c|c|c|c|c|c|}
\hline & 2014 & 2015 & 2016 & 2017 & 2018 & 2019 & $\begin{array}{c}\% \\
\text { Change } \\
\text { 2018-19 }\end{array}$ & 2014 & 2015 & 2016 & 2017 & 2018 & 2019 & $\begin{array}{c}\% \\
\text { Change } \\
2018-19\end{array}$ \\
\hline & \multicolumn{7}{|c|}{$\begin{array}{c}\text { North } \mathrm{MT}^{1} \text { - Santos }{ }^{2} \text { by truck } \\
\text {-US\$/mt- }\end{array}$} & \multicolumn{7}{|c|}{$\begin{array}{c}\text { Northwest RS }{ }^{1} \text { - Rio Grande } \\
\text { - US\$/mt- }\end{array}$} \\
\hline Truck & 103.90 & 86.04 & 75.49 & 92.95 & 91.76 & 79.28 & -13.6 & 24.56 & 26.37 & 18.38 & 30.72 & 29.20 & 25.06 & -14.2 \\
\hline Ocean & 36.85 & 23.81 & 16.63 & 26.88 & 30.31 & 33.65 & 11.0 & 37.02 & 25.31 & 20.50 & 27.30 & 31.06 & 33.94 & 9.3 \\
\hline Total transportation & 140.75 & 109.86 & 92.12 & 119.82 & 122.08 & 112.92 & -7.5 & 61.58 & 51.68 & 38.88 & 58.02 & 60.27 & 58.99 & -2.1 \\
\hline Farm gate price ${ }^{3}$ & 388.33 & 295.17 & 331.91 & 293.60 & 306.03 & 285.35 & -6.8 & 442.52 & 331.55 & 352.69 & 322.30 & 333.21 & 305.56 & -8.3 \\
\hline Landed cost & 529.08 & 405.02 & 424.03 & 413.43 & 428.11 & 398.28 & -7.0 & 504.10 & 383.23 & 391.57 & 380.32 & 393.48 & 364.56 & -7.3 \\
\hline \multirow[t]{2}{*}{ Transport \% of landed cost } & 27.8 & 27.1 & 21.9 & 29.0 & 28.5 & 28.4 & -0.4 & 12.2 & 13.5 & 9.9 & 15.3 & 15.3 & 16.2 & 5.7 \\
\hline & \multicolumn{7}{|c|}{$\begin{array}{l}\text { North } \mathrm{MT}^{1}{ }^{-} \text {Santos }^{2} \text { by truck and rail } \\
\text {-US\$/mt- }\end{array}$} & \multicolumn{7}{|c|}{$\begin{array}{c}\text { South } \mathrm{GO}^{1} \text { - Santos } \\
\text {-US\$/mt- }\end{array}$} \\
\hline Truck & - & - & - & - & 33.49 & 27.62 & -17.5 & 62.57 & 39.82 & 34.66 & 44.22 & 43.25 & 37.34 & -13.7 \\
\hline Rail $^{4}$ & - & - & - & - & 43.29 & 39.98 & -7.6 & - & - & - & - & - & - & - \\
\hline Ocean & - & - & - & - & 30.31 & 33.65 & 11.0 & 36.85 & 23.81 & 16.63 & 26.88 & 30.31 & 33.65 & 11.0 \\
\hline Total transportation & - & - & - & - & 107.10 & 101.25 & -5.5 & 99.42 & 63.63 & 51.28 & 71.09 & 73.56 & 70.98 & -3.5 \\
\hline Farm gate price ${ }^{3}$ & - & - & - & - & 306.03 & 285.35 & -6.8 & 401.49 & 304.36 & 329.15 & 301.99 & 312.31 & 291.46 & -6.7 \\
\hline Landed cost & - & - & - & - & 413.13 & 386.60 & -6.4 & 500.91 & 368.00 & 380.43 & 373.08 & 385.88 & 362.45 & -6.1 \\
\hline Transport $\%$ of landed cost & - & - & - & - & 25.9 & 26.2 & 1.0 & 19.8 & 17.2 & 13.6 & 19.1 & 19.1 & 19.6 & 2.8 \\
\hline
\end{tabular}

${ }^{1}$ Producing regions: $\mathrm{RS}=$ Rio Grande do Sul, MT= Mato Grosso, and GO = Goiás.

${ }^{2}$ Export ports.

${ }^{3}$ The source of the farm gate price is the Brazilian Government, Companhia Nacional de Abastecimento (CONAB).

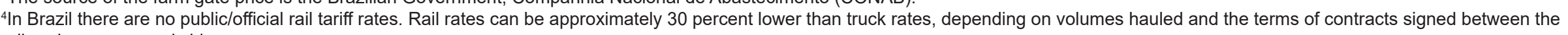
railroad company and shippers.

Note: $\mathrm{mt}=$ metric ton .

Source: University of São Paulo, Escola Superior de Agricultura "Luiz de Queiroz," Brazil (ESALQ/USP) and USDA, Agricultural Marketing Service. 
In 2019, Brazilian soybean transportation costs from Mato Grosso, as a percentage of total landed costs, decreased 1-3 percent and slightly declined from Rio Grande do Sul to Hamburg, Germany, from a year earlier.

Costs of transporting Brazilian soybeans from the southern ports to Hamburg, Germany, $2014-19$

\begin{tabular}{|c|c|c|c|c|c|c|c|c|c|c|c|c|c|c|}
\hline & 2014 & 2015 & 2016 & 2017 & 2018 & 2019 & $\begin{array}{c}\% \\
\text { Change } \\
2018-19\end{array}$ & 2014 & 2015 & 2016 & 2017 & 2018 & 2019 & $\begin{array}{c}\% \\
\text { Change } \\
2018-19\end{array}$ \\
\hline & \multicolumn{7}{|c|}{$\begin{array}{l}\text { North } \mathrm{MT}^{1} \text { - Santos }{ }^{2} \text { by truck } \\
\text {-US\$/mt- }\end{array}$} & \multicolumn{7}{|c|}{$\begin{array}{l}\text { Northwest } \text { RS }^{1} \text { - Rio Grande }{ }^{2} \\
\text {-US\$ } \$ \mathrm{mt}-\end{array}$} \\
\hline Truck & 103.90 & 86.04 & 75.49 & 92.95 & 91.76 & 79.28 & -13.6 & 24.56 & 26.37 & 23.85 & 30.72 & 29.20 & 25.06 & -14.2 \\
\hline Ocean & 27.75 & 19.75 & 18.13 & 24.50 & 25.25 & 25.63 & 1.5 & 27.00 & 20.25 & 17.25 & 25.50 & 26.25 & 25.63 & -2.4 \\
\hline Total transportation & 131.65 & 105.79 & 93.62 & 117.45 & 117.01 & 104.90 & -10.4 & 51.56 & 46.62 & 41.10 & 56.22 & 55.45 & 50.68 & -8.6 \\
\hline Farm gate price ${ }^{3}$ & 388.33 & 295.17 & 331.91 & 293.60 & 306.03 & 285.35 & -6.8 & 442.52 & 331.55 & 348.28 & 322.30 & 333.21 & 305.56 & -8.3 \\
\hline Landed cost & 519.98 & 400.96 & 425.53 & 411.05 & 423.05 & 390.25 & -7.8 & 494.08 & 378.17 & 389.37 & 378.52 & 388.66 & 356.25 & -8.3 \\
\hline \multirow[t]{2}{*}{ Transport $\%$ of landed cost } & 25.3 & 26.3 & 22.1 & 28.6 & 27.6 & 26.9 & -2.7 & 10.5 & 12.3 & 10.6 & 14.9 & 14.3 & 14.2 & -0.3 \\
\hline & \multicolumn{7}{|c|}{$\begin{array}{c}\text { North } \mathrm{MT}^{1} \text { - Santos }{ }^{2} \text { by truck and rail } \\
\text {-US\$/mt- }\end{array}$} & \multicolumn{7}{|c|}{$\begin{array}{c}\text { South } \mathrm{GO}^{1} \text { - Santos } \\
\text {-US\$/mt- }\end{array}$} \\
\hline Truck & - & - & - & - & 33.49 & 27.62 & -17.5 & 62.57 & 39.82 & 34.66 & 44.22 & 43.25 & 37.34 & -13.7 \\
\hline Rail $^{4}$ & - & - & - & - & 43.29 & 39.98 & -7.6 & - & - & - & - & - & & - \\
\hline Ocean & - & - & - & - & 25.25 & 25.63 & 1.5 & 27.75 & 19.75 & 18.13 & 24.50 & 25.25 & 25.63 & 1.5 \\
\hline Total transportation & - & - & - & - & 102.03 & 93.23 & -8.6 & 90.32 & 59.57 & 52.78 & 68.72 & 68.50 & 62.96 & -8.1 \\
\hline Farm gate price ${ }^{3}$ & - & - & - & - & 306.03 & 285.35 & -6.8 & 401.49 & 304.36 & 329.15 & 301.99 & 312.3 & 291.5 & -6.7 \\
\hline Landed cost & - & - & - & - & 408.07 & 378.58 & -7.2 & 491.81 & 363.94 & 381.93 & 370.71 & 380.81 & 354.42 & -6.9 \\
\hline Transport \% of landed cost & - & - & - & - & 25.0 & 24.6 & -1.6 & 18.3 & 16.3 & 13.9 & 18.6 & 18.0 & 17.8 & -1.3 \\
\hline
\end{tabular}

${ }^{1}$ Producing regions: $\mathrm{RS}=$ Rio Grande do Sul, MT= Mato Grosso, and GO = Goiás.

${ }^{2}$ Export ports.

${ }^{3}$ The source of the farm gate price is the Brazilian Government, Companhia Nacional de Abastecimento (CONAB).

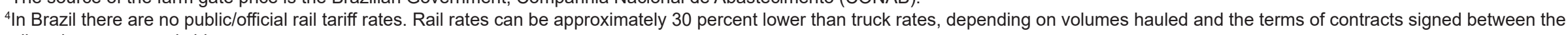
railroad company and shippers.

Note: $\mathrm{mt}=$ metric ton

Source: University of São Paulo, Escola Superior de Agricultura "Luiz de Queiroz," Brazil (ESALQ/USP) and USDA, Agricultural Marketing Service. 
Transportation costs, from the selected route of the northern and northeastern ports, to Shanghai, China, and Hamburg, Germany, decreased.

\section{Cost of transporting soybeans from the northern and northeastern ports to Shanghai, China, 2017-19}

\begin{tabular}{|c|c|c|c|c|c|c|c|c|}
\hline & 2017 & 2018 & 2019 & $\begin{array}{c}\% \\
\text { Change } \\
\text { 2018-19 }\end{array}$ & 2017 & 2018 & 2019 & $\begin{array}{c}\% \\
\text { Change } \\
\text { 2018-19 }\end{array}$ \\
\hline & \multicolumn{4}{|c|}{$\begin{array}{c}\text { North } \mathrm{MT}^{1} \text { - Santarém }{ }^{2} \\
\text {-US\$/mt- }\end{array}$} & \multicolumn{4}{|c|}{$\begin{array}{c}\text { South } \mathrm{MA}^{1} \text { - São Luís } \\
\text {-US\$/mt- }\end{array}$} \\
\hline Truck & 55.08 & 58.86 & 52.04 & -11.6 & 37.69 & 37.60 & 32.99 & -12.3 \\
\hline Ocean & 30.75 & 34.81 & 35.06 & 0.7 & 29.56 & 33.89 & 34.81 & 2.7 \\
\hline Total transportation & 85.83 & 93.67 & 87.10 & -7.0 & 67.25 & 71.48 & 67.80 & -5.2 \\
\hline Farm gate price ${ }^{3}$ & 293.60 & 306.03 & 285.35 & -6.8 & 343.39 & 333.03 & 297.05 & -10.8 \\
\hline Landed cost & 379.43 & 399.70 & 372.45 & -6.8 & 410.64 & 404.51 & 364.85 & -9.8 \\
\hline \multirow[t]{2}{*}{ Transport $\%$ of landed cost } & 22.7 & 23.4 & 23.4 & -0.1 & 16.4 & 17.7 & 18.6 & 5.0 \\
\hline & \multicolumn{4}{|c|}{$\begin{array}{c}\text { Southwest } \text { PI }^{1} \text { - São Luís } \\
\text {-US\$/mt- }\end{array}$} & \multicolumn{4}{|c|}{$\begin{array}{c}\text { North } \mathrm{MT}^{1} \text { - Barcarena } \\
\text { - US\$/mt- }\end{array}$} \\
\hline Truck & 44.44 & 46.52 & 39.34 & -15.4 & - & - & 46.64 & - \\
\hline Barge $^{4}$ & - & - & - & - & - & - & 18.85 & - \\
\hline Ocean & 29.56 & 33.89 & 34.81 & 2.7 & - & - & 34.96 & - \\
\hline Total transportation & 74.00 & 80.41 & 74.15 & -7.8 & - & - & 100.45 & - \\
\hline Farm gate price 3 & 283.05 & 306.26 & 295.87 & -3.4 & - & - & 285.35 & - \\
\hline Landed cost & 357.05 & 386.67 & 370.02 & -4.3 & - & - & 385.80 & - \\
\hline Transport \% of landed cost & 21.0 & 20.8 & 20.9 & 0.3 & - & - & 26.1 & - \\
\hline
\end{tabular}

${ }^{1}$ Producing regions: $\mathrm{MT}=$ Mato Grosso, $\mathrm{PI}=$ Piauí, and MA = Maranhão.

${ }^{2}$ Export port.

${ }^{3}$ The source of the farm gate price is the Brazilian Government, Companhia Nacional de Abastecimento (CONAB).

${ }^{4}$ In Brazil, there are no public/official barge rates. Barge rates can be up to 60 percent lower than truck rates, depending on the volumes hauled and the terms of contracts signed between the barge company and shippers. The distance is in nautical miles.

Note: $\mathrm{mt}=$ metric ton .

Source: University of São Paulo, Escola Superior de Agricultura “Luiz de Queiroz," Brazil (ESALQ/USP) and USDA, Agricultural Marketing Service. 


\section{Cost of transporting soybeans from the northern and northeastern ports to Hamburg, Germany, 2017-19}

\begin{tabular}{|c|c|c|c|c|c|c|c|c|}
\hline & 2017 & 2018 & 2019 & $\begin{array}{c}\% \\
\text { Change } \\
\text { 2018-19 }\end{array}$ & 2017 & 2018 & 2019 & $\begin{array}{c}\% \\
\text { Change } \\
\text { 2018-19 }\end{array}$ \\
\hline & \multicolumn{4}{|c|}{$\begin{array}{c}\text { North } \mathrm{MT}^{1} \text { - Santarém } \\
\text {-US\$ } \$ \mathrm{mt}-\end{array}$} & \multicolumn{4}{|c|}{$\begin{array}{c}\text { South MA }{ }^{1} \text { - São Luís }{ }^{2} \\
\text {-US\$/mt- }\end{array}$} \\
\hline Truck & 55.08 & 58.86 & 52.04 & -11.6 & 37.69 & 37.60 & 32.99 & -12.3 \\
\hline Ocean & 23.90 & 23.35 & 23.42 & 0.3 & 20.20 & 19.40 & 20.34 & 4.9 \\
\hline Total transportation & 78.98 & 82.21 & 75.45 & -8.2 & 57.89 & 57.00 & 53.33 & -6.4 \\
\hline Farm gate price ${ }^{3}$ & 293.60 & 306.03 & 285.35 & -6.8 & 343.39 & 333.03 & 297.05 & -10.8 \\
\hline Landed cost & 372.58 & 388.24 & 360.81 & -7.1 & 401.28 & 390.02 & 350.38 & -10.2 \\
\hline \multirow[t]{2}{*}{ Transport $\%$ of landed cost } & 21.2 & 21.2 & 20.9 & -1.1 & 14.4 & 14.6 & 15.2 & 4.0 \\
\hline & \multicolumn{4}{|c|}{$\begin{array}{c}\text { Southwest } \text { PI }^{1} \text { - São Luís } \\
-U S \$ / m t-\end{array}$} & \multicolumn{4}{|c|}{$\begin{array}{c}\text { North } \mathrm{MT}^{1} \text { - Barcarena }{ }^{2} \\
\text {-US\$/mt- }\end{array}$} \\
\hline Truck & 44.44 & 46.52 & 39.34 & -15.4 & - & - & 46.64 & - \\
\hline Barge $^{4}$ & $=$ & - & - & - & - & - & 18.85 & - \\
\hline Ocean & 20.20 & 19.40 & 20.34 & 4.9 & - & - & 21.16 & - \\
\hline Total transportation & 64.64 & 65.92 & 59.68 & -9.5 & - & - & 86.64 & - \\
\hline Farm gate price ${ }^{3}$ & 283.05 & 306.26 & 295.87 & -3.4 & - & - & 285.35 & - \\
\hline Landed cost & 347.68 & 372.18 & 355.55 & -4.5 & - & - & 372.00 & - \\
\hline Transport $\%$ of landed cost & 18.9 & 17.7 & 16.8 & -5.2 & - & - & 23.3 & - \\
\hline
\end{tabular}

${ }^{1}$ Producing regions: $\mathrm{MT}=$ Mato Grosso, $\mathrm{PI}=$ Piauí, and $\mathrm{MA}=$ Maranhão.

${ }^{2}$ Export port.

${ }^{3}$ The source of the farm gate price is the Brazilian Government, Companhia Nacional de Abastecimento (CONAB).

${ }^{4}$ In Brazil, there are no public/official barge rates. Barge rates can be up to 60 percent lower than truck rates, depending on the volumes hauled and the terms of contracts signed between the barge company and shippers. The distance is in nautical miles.

Note: $\mathrm{mt}=$ metric ton

Source: University of São Paulo, Escola Superior de Agricultura “Luiz de Queiroz," Brazil (ESALQ/USP) and USDA, Agricultural Marketing Service. 
In 2019, U.S. soybean transportation costs from lowa through the U.S. Gulf to Hamburg, Germany increased about 1 percent in response to higher rail rates during the first half of the year. The U.S. soybean transportation costs from Minnesota and lowa through the U.S. Gulf to Shanghai, as a percentage of total landed costs, increased 8-10 percent compared to 2018, as a result of lower farm prices and higher transportation costs. Barge rates declined 16-27 percent, compared to 2018, responding to lower corn transportation demand. Wet weather and a shortage of propane gas delayed corn planting and harvest, weakening barge transportation demand. Propane gas is the most widely used and cost-effective fuel option for grain dryers in corn production.

Average costs of transporting U.S. soybeans to Hamburg, Germany, and Shanghai, China, 2015-19

\begin{tabular}{|c|c|c|c|c|c|c|c|c|c|c|c|c|}
\hline & 2015 & 2016 & 2017 & 2018 & 2019 & $\begin{array}{c}\% \\
\text { Change } \\
\text { 2018-19 }\end{array}$ & 2015 & 2016 & 2017 & 2018 & 2019 & $\begin{array}{c}\% \\
\text { Change } \\
\text { 2018-19 }\end{array}$ \\
\hline & \multicolumn{12}{|c|}{ To Hamburg, Germany } \\
\hline & \multicolumn{6}{|c|}{$\begin{array}{c}\text { Minneapolis, Minnesota } \\
\text {-US\$/mt- }\end{array}$} & \multicolumn{6}{|c|}{$\begin{array}{l}\text { Davenport, lowa } \\
\text { - US\$/mt- }\end{array}$} \\
\hline Truck & 10.23 & 10.36 & 12.71 & 12.14 & 10.10 & -16.8 & 10.23 & 10.36 & 12.71 & 12.14 & 10.10 & -16.8 \\
\hline Rail $^{1}$ & 42.09 & 43.30 & 45.91 & 46.37 & 47.96 & 3.4 & 31.20 & 11.65 & 34.98 & 30.92 & 32.13 & 3.9 \\
\hline Barge $^{2}$ & 27.49 & 24.32 & 22.62 & 29.97 & 21.99 & -26.6 & 22.15 & 18.72 & 17.60 & 24.51 & 20.43 & -16.7 \\
\hline Ocean $^{3}$ & 14.32 & 13.83 & 15.46 & 19.85 & 18.15 & -8.6 & 14.32 & 19.20 & 15.47 & 19.85 & 18.15 & -8.6 \\
\hline Total transportation ${ }^{4}$ & 62.56 & 59.33 & 62.26 & 73.55 & 74.22 & 0.9 & 54.50 & 51.19 & 54.53 & 64.23 & 64.73 & 0.8 \\
\hline Farm price ${ }^{5}$ & 342.91 & 335.81 & 338.20 & 330.51 & 305.65 & -7.5 & 344.69 & 340.89 & 344.53 & 336.05 & 307.27 & -8.6 \\
\hline Landed cost ${ }^{6}$ & 405.47 & 395.14 & 400.46 & 404.06 & 379.86 & -6.0 & 399.19 & 392.08 & 399.06 & 400.28 & 372.00 & -7.1 \\
\hline \multirow[t]{3}{*}{$\begin{array}{l}\text { Transport } \% \text { of } \\
\text { landed cost } \\
\end{array}$} & 15.3 & 15.1 & 15.5 & 18.1 & 19.4 & 7.0 & 13.6 & 13.1 & 13.6 & 16.0 & 17.4 & 8.4 \\
\hline & \multicolumn{12}{|c|}{ To Shanghai, China } \\
\hline & \multicolumn{6}{|c|}{$\begin{array}{c}\text { Minneapolis, Minnesota } \\
\text {-US\$/mt- }\end{array}$} & \multicolumn{6}{|c|}{$\begin{array}{c}\text { Davenport, lowa } \\
\text {-US\$\$/mt- }\end{array}$} \\
\hline Truck & 14.13 & 10.36 & 12.71 & 12.14 & 10.10 & -16.8 & 10.23 & 10.36 & 12.71 & 12.14 & 10.10 & -16.8 \\
\hline Rail $^{1}$ & 42.09 & 43.30 & 45.91 & 46.37 & 47.96 & 3.4 & 31.20 & 33.12 & 34.98 & 30.92 & 32.12 & 3.9 \\
\hline Barge $^{2}$ & 27.49 & 24.32 & 22.62 & 29.97 & 21.99 & -26.6 & 22.15 & 18.72 & 17.60 & 24.51 & 20.43 & -16.7 \\
\hline Ocean $^{3}$ & 30.09 & 26.65 & 38.37 & 44.42 & 44.55 & 0.3 & 30.09 & 26.65 & 38.37 & 44.42 & 44.55 & 0.3 \\
\hline Total transportation ${ }^{4}$ & 78.33 & 72.15 & 85.17 & 98.12 & 100.62 & 2.6 & 69.67 & 64.00 & 77.43 & 88.80 & 91.14 & 2.6 \\
\hline Farm price $^{5}$ & 342.91 & 335.81 & 338.20 & 330.56 & 305.65 & -7.5 & 344.69 & 340.89 & 344.53 & 336.05 & 307.27 & -8.6 \\
\hline Landed cost ${ }^{6}$ & 421.24 & 407.96 & 423.37 & 428.68 & 406.27 & -5.2 & 414.96 & 404.90 & 421.96 & 424.85 & 398.41 & -6.2 \\
\hline $\begin{array}{l}\text { Transport \% of } \\
\text { landed cost }\end{array}$ & 18.5 & 17.8 & 20.1 & 22.8 & 24.7 & 8.1 & 16.9 & 15.9 & 18.3 & 20.9 & 22.9 & 9.5 \\
\hline
\end{tabular}

${ }^{1}$ Rail rates include fuel surcharges, but do not include the cost of purchasing empty rail cars in the secondary rail markets, which could exceed the rail tariff rate plus fuel surcharge shown in the table.

${ }^{2}$ The Mississippi River closes from Minneapolis to just north of St. Louis during mid-December to late March; The distance by barge between Minneapolis and Davenport to the Port of New Orleans is 1,713 and 1,343 miles, respectively.

35ource: The Baltic Exchange and O'Neil Commodity Consulting; excludes handling charges.

${ }^{4}$ The average of the sum of the total costs may not be equal to the sum of the individual average costs of truck, rail, barge, and ocean because rail is used only in the first quarter.

${ }^{5}$ Source for the U.S. farm prices: USDA, National Agricultural Statistics Service.

${ }^{6}$ Landed cost is transportation cost plus farm price.

Note: $\mathrm{mt}=$ metric ton; total may not add exactly due to rounding.

Source: Compiled by the USDA, Agricultural Marketing Service. 
The U.S. soybean transportation costs, as a percentage of total landed costs, from North and South Dakota, via the Pacific Northwest (PNW) to Shanghai, China, increased 6-8 percent from a year earlier in response to lower soybean prices.

Average costs of transporting U.S. soybeans to Shanghai, China, 2015-19

\begin{tabular}{|c|c|c|c|c|c|c|c|c|c|c|c|c|}
\hline & 2015 & 2016 & 2017 & 2018 & 2019 & $\begin{array}{c}\% \\
\text { Change } \\
\text { 2018-19 }\end{array}$ & 2015 & 2016 & 2017 & 2018 & 2019 & $\begin{array}{c}\% \\
\text { Change } \\
2018-19\end{array}$ \\
\hline & \multicolumn{12}{|c|}{ To Shanghai, China via PNW } \\
\hline & \multicolumn{6}{|c|}{$\begin{array}{c}\text { Fargo, ND } \\
\text { - US\$/mt- }\end{array}$} & \multicolumn{6}{|c|}{$\begin{array}{c}\text { Sioux Falls, SD } \\
\text { - US\$/mt- }\end{array}$} \\
\hline Truck & 10.23 & 10.36 & 12.71 & 12.14 & 10.10 & -16.8 & 10.23 & 10.44 & 12.71 & 12.14 & 10.10 & -16.8 \\
\hline Rail $^{1}$ & 55.98 & 53.04 & 54.66 & 55.12 & 56.36 & 2.3 & 57.20 & 54.02 & 55.65 & 56.11 & 57.35 & 2.2 \\
\hline Ocean ${ }^{2}$ & 16.34 & 14.90 & 20.37 & 24.34 & 24.59 & 1.0 & 16.34 & 14.90 & 20.37 & 24.34 & 24.59 & 1.0 \\
\hline Total transportation & 82.55 & 78.30 & 87.74 & 91.60 & 91.05 & -0.6 & 83.77 & 79.31 & 88.74 & 92.59 & 92.04 & -0.6 \\
\hline Farm price ${ }^{3}$ & 322.98 & 327.42 & 324.57 & 319.55 & 285.65 & -10.6 & 329.87 & 328.98 & 328.98 & 320.38 & 293.98 & -8.2 \\
\hline Landed cost ${ }^{4}$ & 405.52 & 405.72 & 412.31 & 411.14 & 376.70 & -8.4 & 413.64 & 408.29 & 417.72 & 412.96 & 386.02 & -6.5 \\
\hline $\begin{array}{l}\text { Transport \% of } \\
\text { landed cost }\end{array}$ & 20.4 & 19.3 & 21.3 & 22.3 & 24.2 & 8.3 & 20.3 & 19.4 & 21.2 & 22.5 & 23.8 & 6.1 \\
\hline
\end{tabular}

${ }^{1}$ Rail rates include fuel surcharges, but do not include the cost of purchasing empty rail cars in the secondary rail markets, which could exceed the rail tariff rate plus fuel surcharge shown in the table.

${ }^{2}$ Source for the U.S. ocean freight rates: O'Neil Commodity Consulting.

${ }^{3}$ Source for the U.S. farm prices: USDA, National Agricultural Statistics Service.

${ }^{4}$ Landed cost is transportation cost plus farm price.

Note: $\mathrm{mt}$ = metric ton; PNW = Pacific Northwest; $\mathrm{SD}=$ South Dakota; ND = North Dakota; total may not add exactly due to rounding.

Source: Compiled by the USDA, Agricultural Marketing Service.

In 2019, the cost per metric ton (mt) to ship soybeans from Sorriso, North Mato Grosso to Shanghai, China, was $\$ 21.78$ more than from Davenport, IA. The U.S. cost advantage narrowed from 2018, as the Brazilian transportation costs declined 7 percent and lowa costs increased nearly 3 percent. Sorriso is located 1,190 miles from the port of Santos. Davenport, IA, is about 900 miles by truck, 908 miles by rail, and 1,343 miles by barge, from the Port of New Orleans.

\section{Transportation cost differences between Mato Gross (MT) and Iowa (IA)} to Shanghai, China, 2018-19

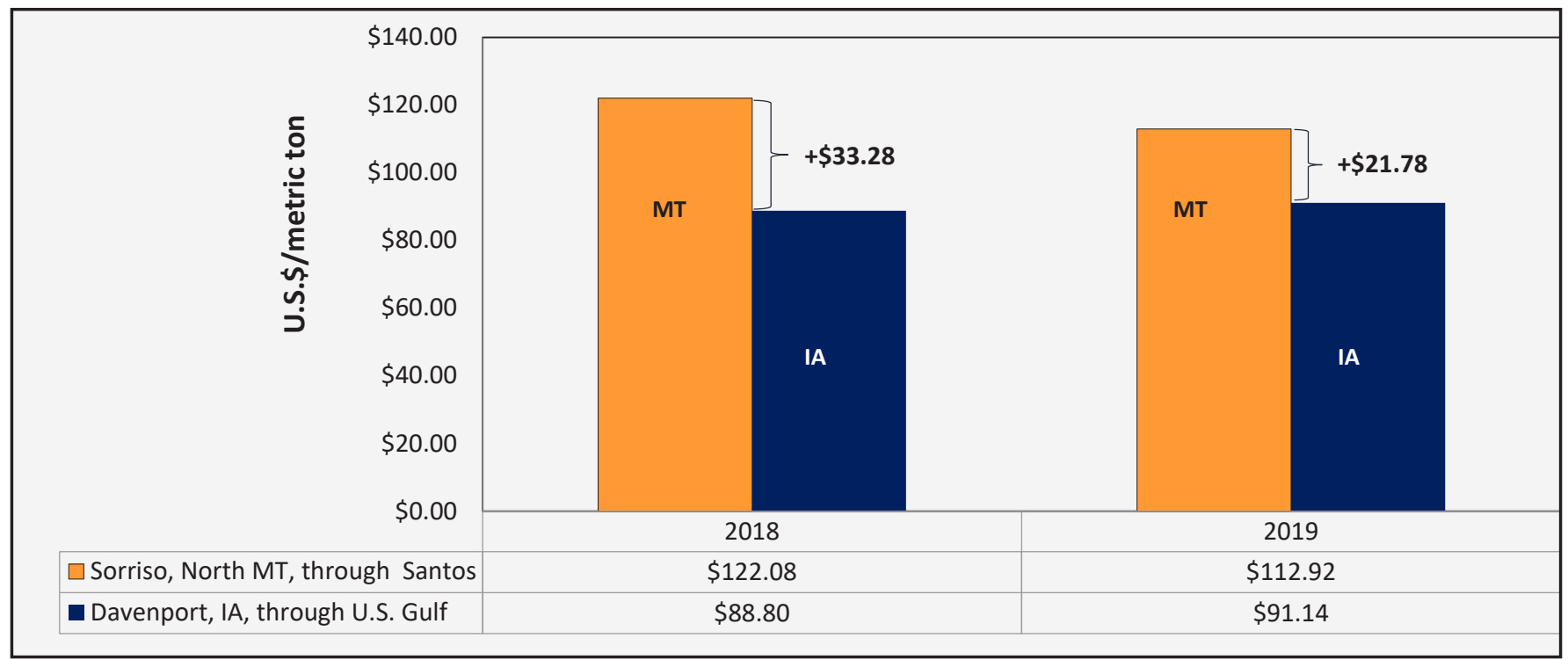


In 2019 the cost of shipping a metric ton of soybeans from Cruz Alta, Northwest Rio Grande do Sul, to Shanghai, China, was $\$ 32.15$ less than from Davenport, IA. The Brazilian cost advantage widened from 2018, as the Brazilian transportation costs declined 2 percent and lowa costs increased nearly 3 percent. The distance from Cruz Alta to the port of Rio Grande is 288 miles.

\section{Transportation cost differences between Rio Grande do Sul (RS) and Iowa (IA) to Shanghai, China, 2018-19}

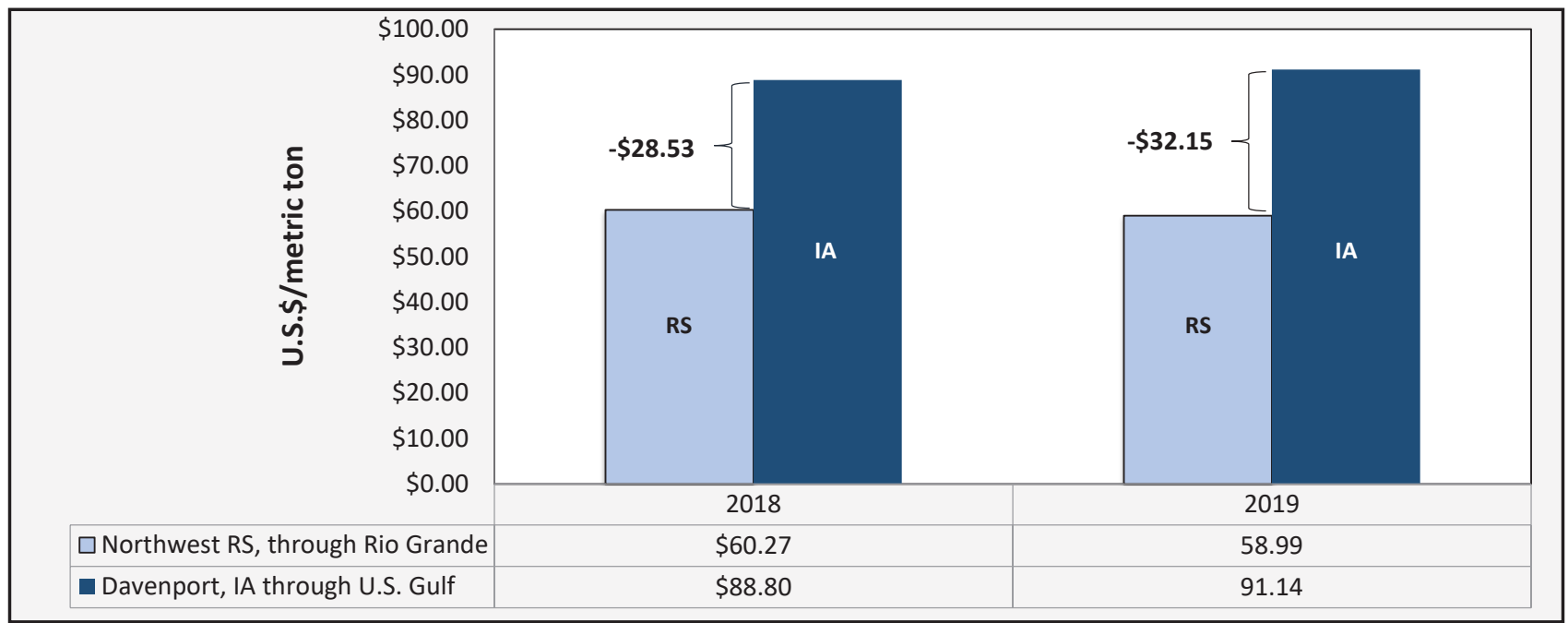

Note: RS = Rio Grande do Sul and IA = lowa.

Source: USDA, Agricultural Marketing Service.

During 2019, Sorriso, North Mato Grosso, soybean shippers to Shanghai paid about \$22 per metric ton more than U.S. exporters, through the U.S. Gulf and PNW routes, when they used trucks. However, the cost advantage narrowed to $\$ 10$ per metric ton when North Mato Grosso soybeans were shipped by rail to Santos and $\$ 9$ per metric ton by barge to Barcarena to Shanghai. In Brazil, there are no public/official rail and barge tariff rates. Rail rates can be up to 30 percent lower than truck rates, and barge rates can be up to 60 percent lower than truck rates, depending on the volumes hauled and the terms of contracts signed between the railroad and barge companies and shippers.

Transportation cost differences between selected Brazil-United States Routes to Shanghai, China, 2019

\begin{tabular}{|l|l|l|l|l|l|}
\hline & \\
\end{tabular}

Note: $\mathrm{MT}=$ Mato Grosso, MA = Maranhão, RS= Rio Grande do Sul, SD = South Dakota, IA = lowa, and ND= North Dakota. Source: USDA, Agricultural Marketing Service. 
In 2019, selected Brazilian export truck routes, measured in reais (R\$), saw proportionally higher transportation costs, than those estimated in U.S. dollars, owing to the depreciation of the Brazilian Real (R\$) against the U.S. dollar and the completion of the BR 163 road paving project, connecting Sorriso, North Mato Grosso to Itaituba, Pará. For example, truck rates, measured in U.S. dollar per metric ton, from Cruz Alta, Rio Grande do Sul to Rio Grande decreased 14 percent. Truck rates from Sorriso, North Mato Grosso to the southern port of Santos and Paranaguá decreased 14-16 percent. Truck rates from North Mato Grosso to Rondonópolis (Rail terminal) and to the northern river ports of Santarém and Itaituba/Miritituba (Barge terminal) decreased 12-18 percent. From 2018 to 2019, the Brazilian real depreciated nearly 7 percent against the U.S. dollar, from R\$3.69 per U.S. dollar to R\$3.94 per U.S. dollar.

Truck rates for selected Brazilian soybean export routes, US\$/metric ton, 2014-19

\begin{tabular}{|c|c|c|c|c|c|c|c|c|c|c|}
\hline \multirow{2}{*}{$\begin{array}{l}\text { Route } \\
\#\end{array}$} & \multirow[t]{2}{*}{ Origin $^{1}$ (reference city) } & \multirow[t]{2}{*}{ Destination } & \multirow{2}{*}{$\begin{array}{c}\text { Distance } \\
\text { (miles) }\end{array}$} & 2014 & 2015 & 2016 & 2017 & 2018 & 2019 & \multirow{2}{*}{$\begin{array}{c}\% \\
\text { change } \\
\text { 2018-19 }\end{array}$} \\
\hline & & & & \multicolumn{6}{|c|}{ Freight price, US\$/metric ton ${ }^{3}$} & \\
\hline 1 & Northwest RS ${ }^{4}$ (Cruz Alta) & Rio Grande & 288 & 24.56 & 26.37 & 23.85 & 30.72 & 29.20 & 25.06 & -14.2 \\
\hline 2 & North MT (Sorriso) & Santos & 1,190 & 103.90 & 86.04 & 75.49 & 92.95 & 91.76 & 79.28 & -13.6 \\
\hline 3 & North MT (Sorriso) & Paranaguá & 1,262 & 100.89 & 85.68 & 74.42 & 89.41 & 90.20 & 75.78 & -16.0 \\
\hline 4 & South GO (Rio Verde) & Santos & 587 & 62.57 & 39.82 & 34.66 & 44.22 & 43.25 & 37.34 & -13.7 \\
\hline 6 & North Central PR (Londrina) & Paranaguá & 268 & 30.98 & 24.07 & 21.31 & 29.29 & 27.22 & 22.64 & -16.8 \\
\hline 11 & Southeast MT (Primavera do Leste) & Santos & 901 & 79.00 & 58.82 & 51.29 & 63.63 & 62.16 & 53.56 & -13.8 \\
\hline 27 & North MT (Sorriso) & Itaituba & 672 & -- na-- & 41.70 & 41.72 & 59.65 & 56.27 & 46.64 & -17.1 \\
\hline 29 & North MT (Sorriso) & Santarém & 876 & -- na-- & 58.12 & 49.60 & 55.08 & 58.86 & 52.04 & -11.6 \\
\hline 30 & South MA (Balsas) & São Luís & 482 & -- na-- & 36.15 & 31.04 & 37.69 & 37.60 & 32.99 & -12.3 \\
\hline 31 & Southwest PI (Bom Jesus) & São Luís & 606 & -- na-- & 43.04 & 34.23 & 44.44 & 46.52 & 39.34 & -15.4 \\
\hline 32 & Southeast PA (Paragominas) & Barcarena & 249 & --na-- & 19.82 & 17.93 & 25.00 & 22.39 & 20.12 & -10.2 \\
\hline 33 & East TO (Campos Lindos) & São Luís & 842 & $--n a--$ & 56.78 & 50.55 & 61.69 & 56.94 & 50.55 & -11.2 \\
\hline 34 & North MT (Sorriso) & $\begin{array}{l}\text { Rondonópolis } \\
\text { (Rail terminal) }\end{array}$ & 382 & $--n a--$ & --na-- & --na-- & --na-- & 33.49 & 27.62 & -17.5 \\
\hline 35 & Rondonópolis MT (Rail teminal) ${ }^{5}$ & Santos & 1019 & --na-- & --na-- & --na-- & --na-- & 43.29 & 39.98 & -7.6 \\
\hline 36 & Itaituba PA (Barge terminal) ${ }^{6}$ & Santarém & 224 & --na-- & --na-- & --na-- & --na-- & --na-- & 14.67 & - \\
\hline 37 & Itaituba PA (Barge terminal) ${ }^{6}$ & Barcarena & 738 & --na-- & --na-- & --na-- & --na-- & --na-- & 18.85 & - \\
\hline
\end{tabular}

${ }^{1}$ Although each origin region comprises several cities, the main city is considered as a reference to establish the freight price; na = not available.

${ }^{2}$ Distance from the main city of the considered region to the mentioned ports.

${ }^{3}$ Average monthly exchange rate from "Banco Central do Brasil" was used to convert Brazilian reais to U.S. dollars.

${ }^{4} \mathrm{RS}=$ Rio Grande do Sul, MT= Mato Grosso, GO = Goiás, PR = Paraná, PI = Piauí, MA = Maranhão, PA = Pará, and TO = Tocantins.

${ }^{5}$ In Brazil, there are no public/official rail tariff rates. Rail rates can be up to 30 percent lower than truck rates, depending on the volumes hauled and the terms of contracts signed between the railroad company and shippers.

${ }^{6}$ In Brazil, there are no public/official barge rates. Barge rates can be up to 60 percent lower than truck rates, depending on the volumes hauled and the terms of contracts signed between the barge company and shippers. The distance is in nautical miles.

Source: University of São Paulo, Escola Superior de Agricultura "Luiz de Queiroz," Brazil (ESALQ/USP) and USDA, Agricultural Marketing Service. 
Truck rates for selected Brazilian soybean export routes, reais/metric ton, 2014-19

\begin{tabular}{|c|c|c|c|c|c|c|c|c|c|c|}
\hline \multirow{2}{*}{$\begin{array}{l}\text { Route } \\
\#\end{array}$} & \multirow{2}{*}{ Origin $^{1}$ (reference city) } & \multirow{2}{*}{ Destination } & \multirow{2}{*}{$\begin{array}{l}\text { Distance } \\
\text { (miles) }\end{array}$} & 2014 & 2015 & 2016 & 2017 & 2018 & 2019 & \multirow{2}{*}{$\begin{array}{c}\% \\
\text { change } \\
2018-19\end{array}$} \\
\hline & & & & \multicolumn{6}{|c|}{ Freight price, reais/metric ton ${ }^{3}$} & \\
\hline 1 & Northwest RS ${ }^{4}$ (Cruz Alta) & Rio Grande & 288 & 57.52 & 87.26 & 83.70 & 97.91 & 106.15 & 98.63 & -7.1 \\
\hline 2 & North MT (Sorriso) & Santos & 1,190 & 243.68 & 283.84 & 263.26 & 296.36 & 334.43 & 312.20 & -6.6 \\
\hline 3 & North MT (Sorriso) & Paranaguá & 1,262 & 236.81 & 282.66 & 259.49 & 285.12 & 328.71 & 298.83 & -9.1 \\
\hline 4 & South GO (Rio Verde) & Santos & 587 & 146.51 & 130.98 & 121.33 & 140.95 & 157.35 & 146.75 & -6.7 \\
\hline 6 & North Central PR (Londrina) & Paranaguá & 268 & 72.47 & 79.44 & 74.77 & 93.34 & 98.87 & 89.07 & -9.9 \\
\hline 11 & Southeast MT (Primavera do Leste) & Santos & 901 & 185.01 & 193.85 & 179.27 & 202.86 & 226.32 & 210.83 & -6.8 \\
\hline 27 & North MT (Sorriso) & Itaituba & 672 & -- na-- & 137.56 & 145.97 & 190.01 & 204.53 & 183.26 & -10.4 \\
\hline 29 & North MT (Sorriso) & Santarém & 876 & -- na-- & 190.47 & 174.02 & 175.70 & 214.29 & 204.53 & -4.6 \\
\hline 30 & South MA (Balsas) & São Luís & 482 & -- na-- & 119.23 & 107.94 & 120.16 & 137.16 & 129.69 & -5.5 \\
\hline 31 & Southwest PI (Bom Jesus) & São Luís & 606 & -- na-- & 141.03 & 119.74 & 141.67 & 169.77 & 154.46 & -9.0 \\
\hline 32 & Southeast PA (Paragominas) & Barcarena & 249 & -- na-- & 65.77 & 62.95 & 79.64 & 81.19 & 78.95 & -2.8 \\
\hline 33 & East TO (Campos Lindos) & São Luís & 842 & -- na-- & 184.72 & 175.24 & 196.74 & 207.55 & 198.95 & -4.1 \\
\hline 34 & North MT (Sorriso) & $\begin{array}{l}\text { Rondonópolis } \\
\text { (Rail terminal) }\end{array}$ & 382 & --na-- & --na-- & --na-- & --na-- & 121.48 & 108.61 & -10.6 \\
\hline 35 & Rondonópolis MT (Rail teminal) ${ }^{5}$ & Santos & 1019 & --na-- & --na-- & -- na-- & --na-- & 157.64 & 157.62 & 0.0 \\
\hline 36 & Itaituba PA (Barge terminal) ${ }^{6}$ & Santarém & 224 & --na-- & --na-- & --na-- & --na-- & --na-- & 25.78 & - \\
\hline 37 & Itaituba PA (Barge terminal) ${ }^{6}$ & Barcarena & 738 & --na-- & --na-- & --na-- & --na-- & --na-- & 74.17 & - \\
\hline
\end{tabular}

${ }^{1}$ Although each origin region comprises several cities, the main city is considered as a reference to establish the freight price; na = not available.

${ }^{2}$ Distance from the main city of the considered region to the mentioned ports.

${ }^{3}$ Average monthly exchange rate from "Banco Central do Brasil" was used to convert Brazilian reais to U.S. dollars.

${ }^{4} \mathrm{RS}=$ Rio Grande do Sul, MT= Mato Grosso, $\mathrm{GO}=$ Goiás, $\mathrm{PR}=$ Paraná, $\mathrm{PI}=$ Piauí, $\mathrm{MA}=$ Maranhão, PA = Pará, and TO = Tocantins.

${ }^{5}$ In Brazil, there are no public/official rail tariff rates. Rail rates can be up to 30 percent lower than truck rates, depending on the volumes hauled and the terms of contracts signed between the railroad company and shippers.

${ }^{6}$ In Brazil, there are no public/official barge rates. Barge rates can be up to 60 percent lower than truck rates, depending on the volumes hauled and the terms of contracts signed between the barge company and shippers. The distance is in nautical miles.

Source: University of São Paulo, Escola Superior de Agricultura "Luiz de Queiroz," Brazil (ESALQ/USP) and USDA, Agricultural Marketing Service. 
In 2019, the Brazilian soybean export transportation cost index increased. The cost of shipping a metric ton (mt) of soybeans 100 miles by truck decreased from \$8.44 in 2018 to \$7.19 in 2019.

\section{Brazilian soybean export truck cost index, 2017-19}

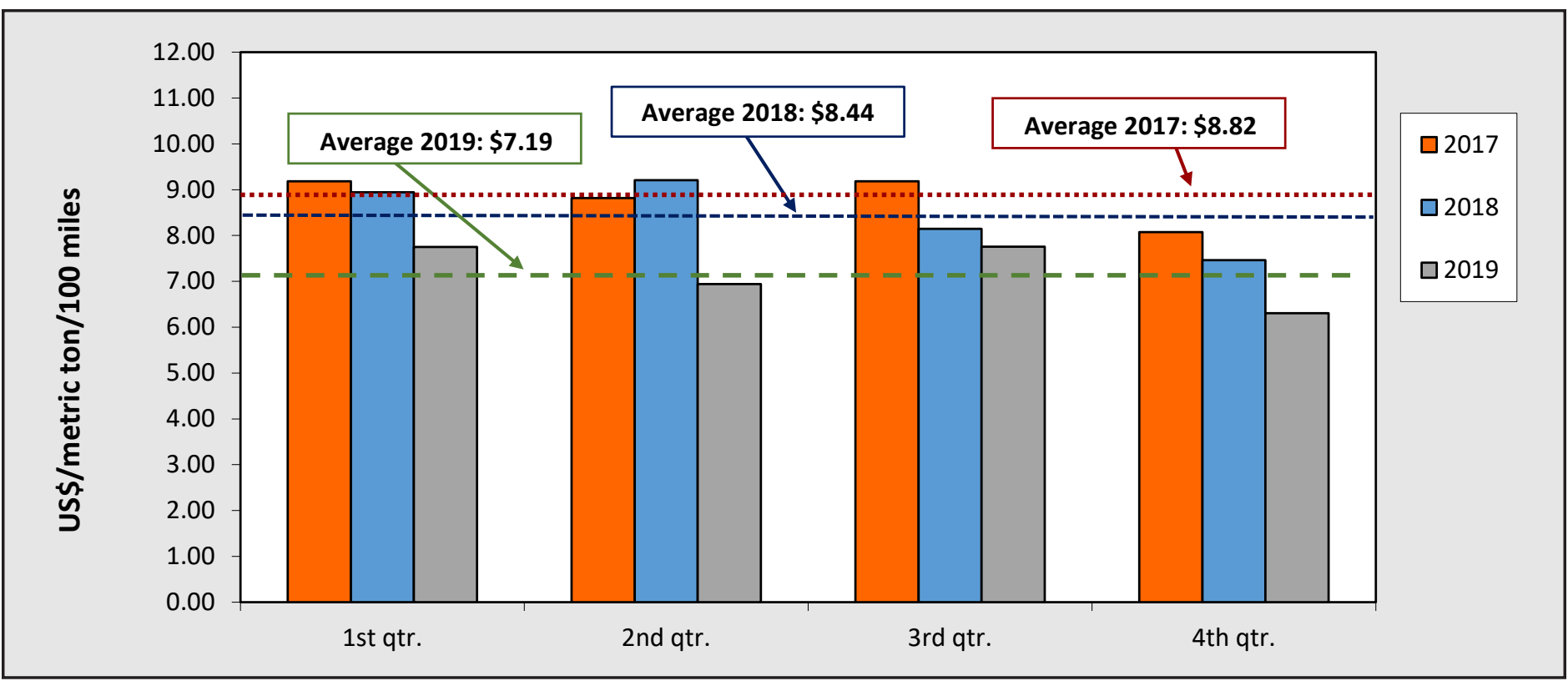

Source: University of São Paulo, Escola Superior de Agricultura “Luiz de Queiroz," Brazil (ESALQ/USP) and USDA, Agricultural Marketing Service.

Brazil is the largest soybean exporting country, followed by the United States, Argentina, Paraguay, and Canada. In 2019, Santos was the largest Brazilian soybean export port, followed by Rio Grande, Paranaguá, São Luís, Barcarena, and São Francisco do Sul. These six ports accounted for 82 percent of Brazil's total exports. Soybean trade is still dominated by the southern ports of Santos, Rio Grande, Paranaguá, and São Francisco do Sul, accounting for nearly 63 percent of Brazil's soybean exports. In 2014, these ports accounted for nearly 73 percent of Brazil soybean exports. Approximately 28 percent of Brazil's soybean exports were shipped through the northeastern ports of São Luís, Vitória, Salvador, and Barcarena in 2019 compared with nearly 21 percent in 2014. In 2019, nearly 8 percent of Brazil's soybean exports were exported through the Amazon River ports of Manaus and Santarém compared with 5 percent in 2014.

Brazilian soybean exports by port, 2017-19

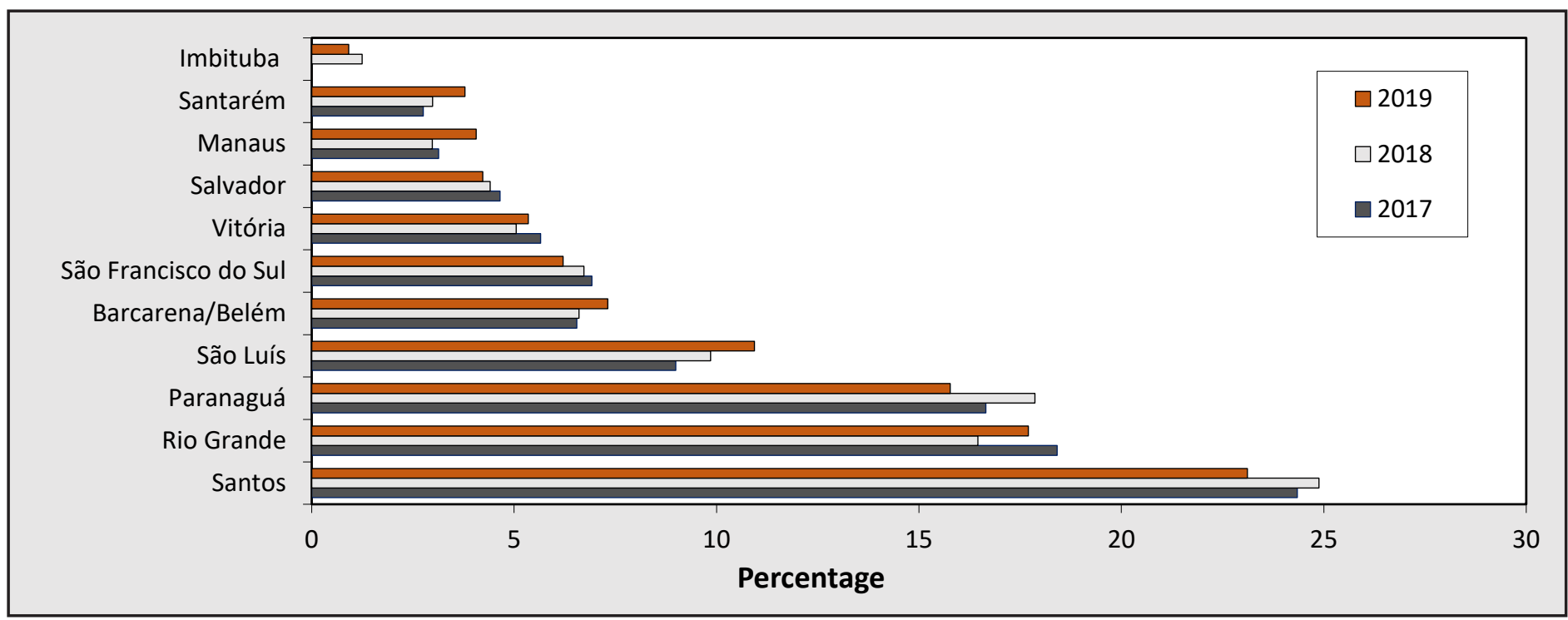

Source: Comex Stat, Ministério da Economia. 
In 2019, ocean rates from the southern Brazilian ports increased 1 percent to Hamburg and 9-13 percent to Shanghai in response to higher bunker fuel prices, higher Brazilian corn exports, and a strong iron ore trade that reduced the availability of Panamax vessels for grain exports at the Brazilian ports. During the first half of 2019, ocean rates from the Port of Santos to Shanghai, China, were unusually low due to lower Chinese iron ore imports and the collapse of a mine-waste dam in southeastern Brazil that disrupted Brazilian iron supply. However, ocean rates increased in the second half of the year, averaging $\$ 33.65 / \mathrm{mt}$.

\section{Brazilian soybean ocean freight from Santos to Shanghai and Hamburg, 2019}

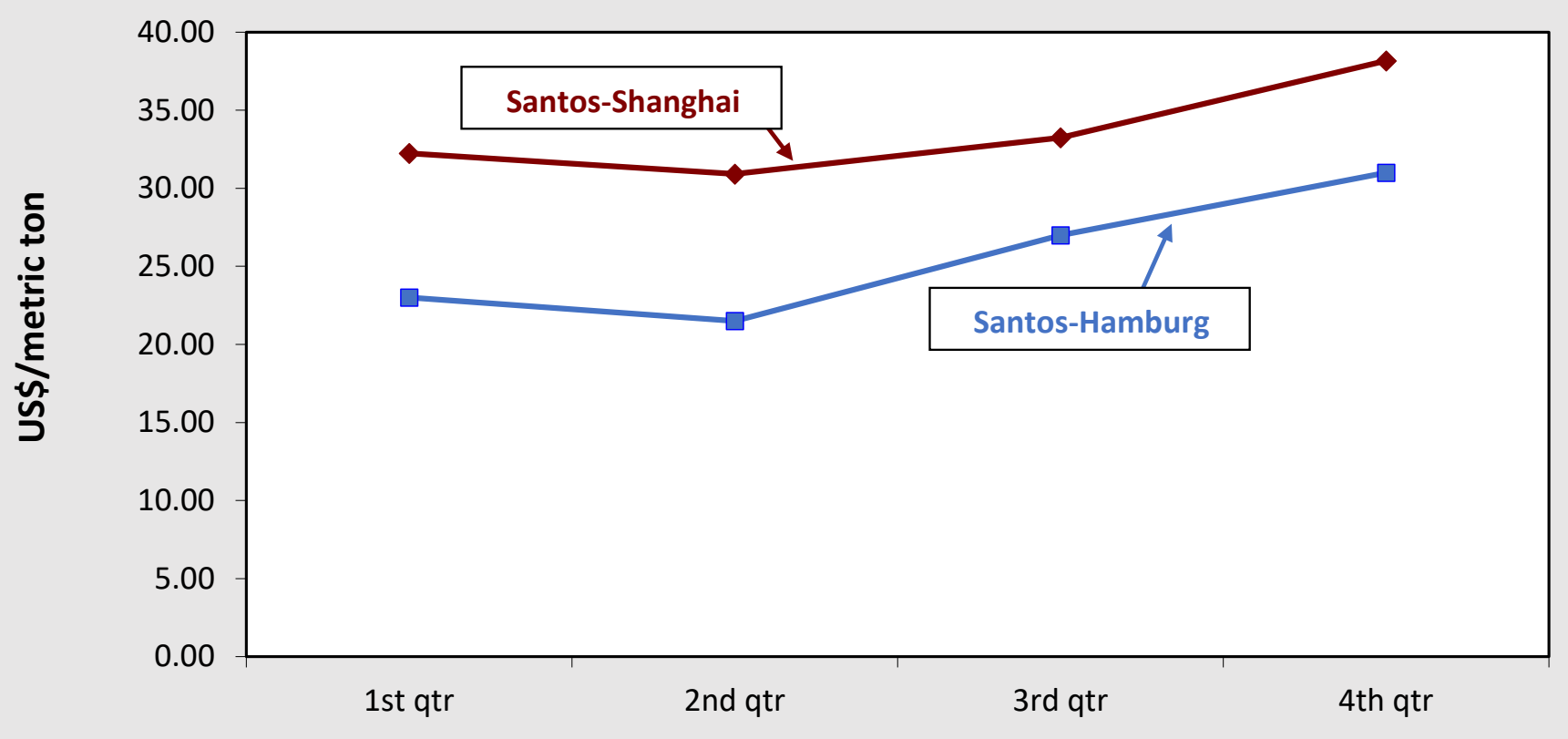

Source: University of São Paulo, Escola Superior de Agricultura “Luiz de Queiroz," Brazil (ESALQ/USP) and USDA, Agricultural Marketing Service.

Brazilian soybean ocean freight from selected ports to Shanghai, China, 2019

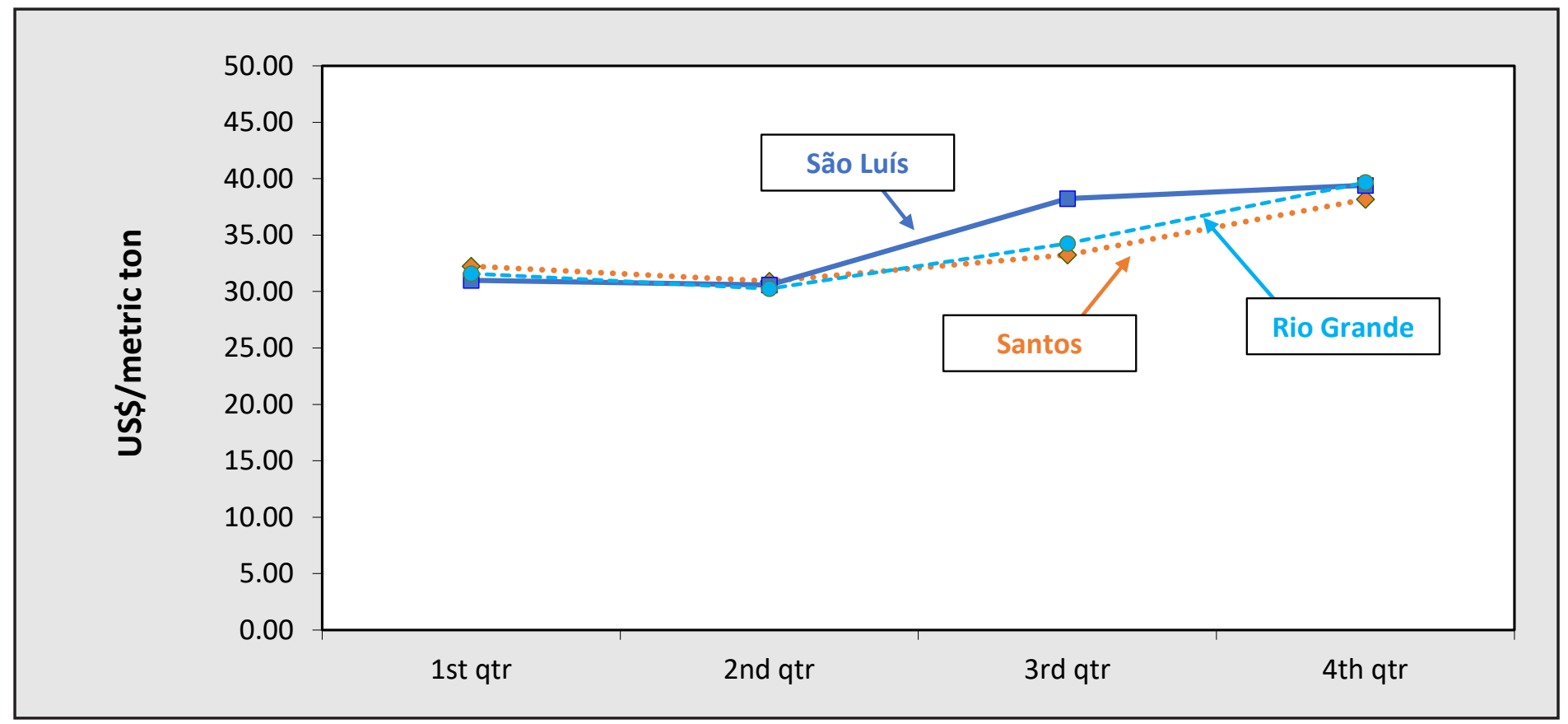

Source: University of São Paulo, Escola Superior de Agricultura “Luiz de Queiroz," Brazil (ESALQ/USP) and USDA, Agricultural Marketing Service. 
The cost to ship $1 \mathrm{mt}$ of soybeans from Brazil to Hamburg, Germany, by oceangoing vessel slightly decreased, on average, from $\$ 25.92 / \mathrm{mt}$ to $\$ 25.58 / \mathrm{mt}$.

Ocean rates from Brazil to Hamburg, Germany, decreased in 2019

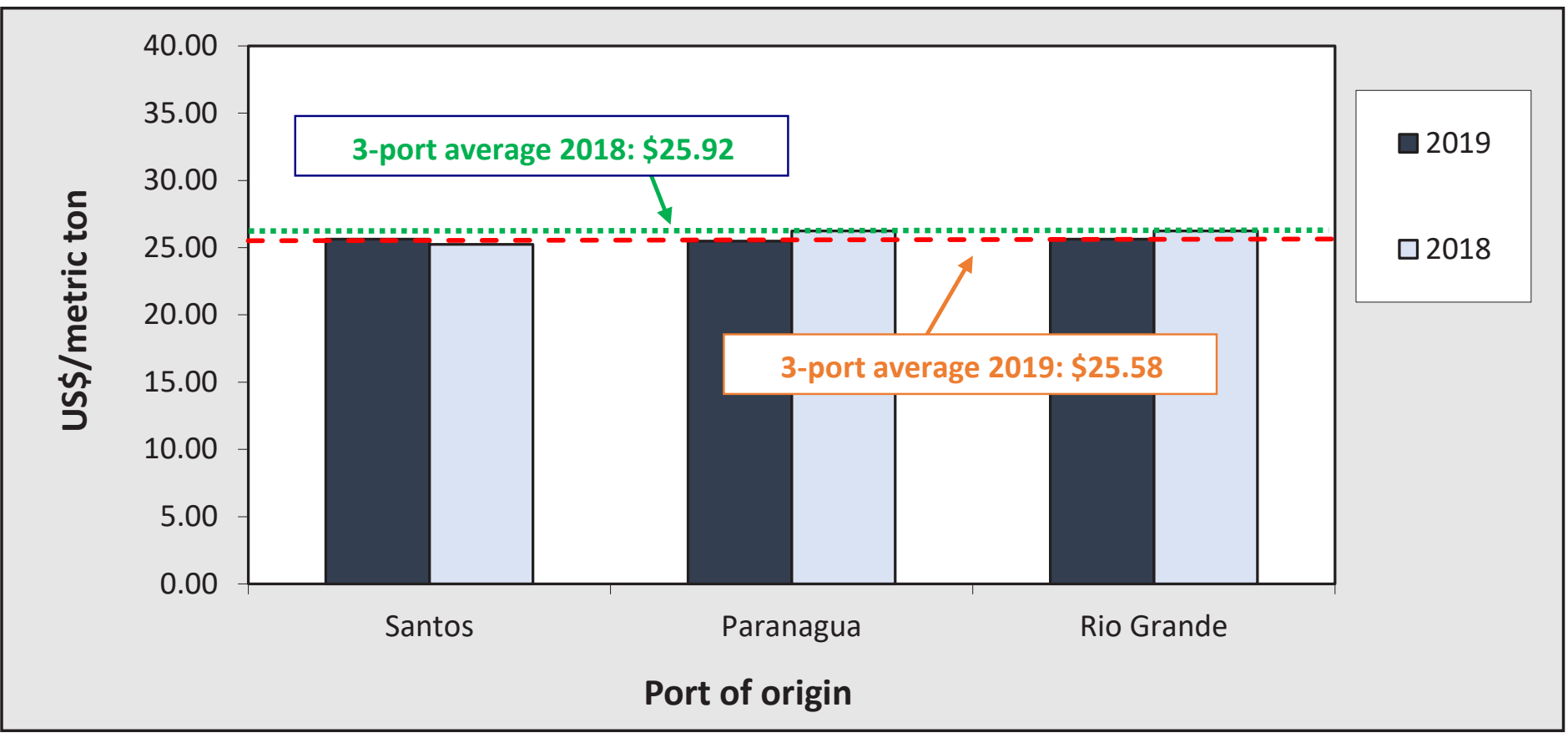

Source: University of São Paulo, Escola Superior de Agricultura “Luiz de Queiroz," Brazil (ESALQ/USP) and USDA, Agricultural Marketing Service.

In 2019, the cost to ship $1 \mathrm{mt}$ of soybeans from Brazil to Shanghai, by ocean vessel, increased 11 percent on average, from $\$ 30.77 / \mathrm{mt}$ to $\$ 34.15 / \mathrm{mt}$.

Ocean rates from Brazil to Shanghai, China, increased in 2019

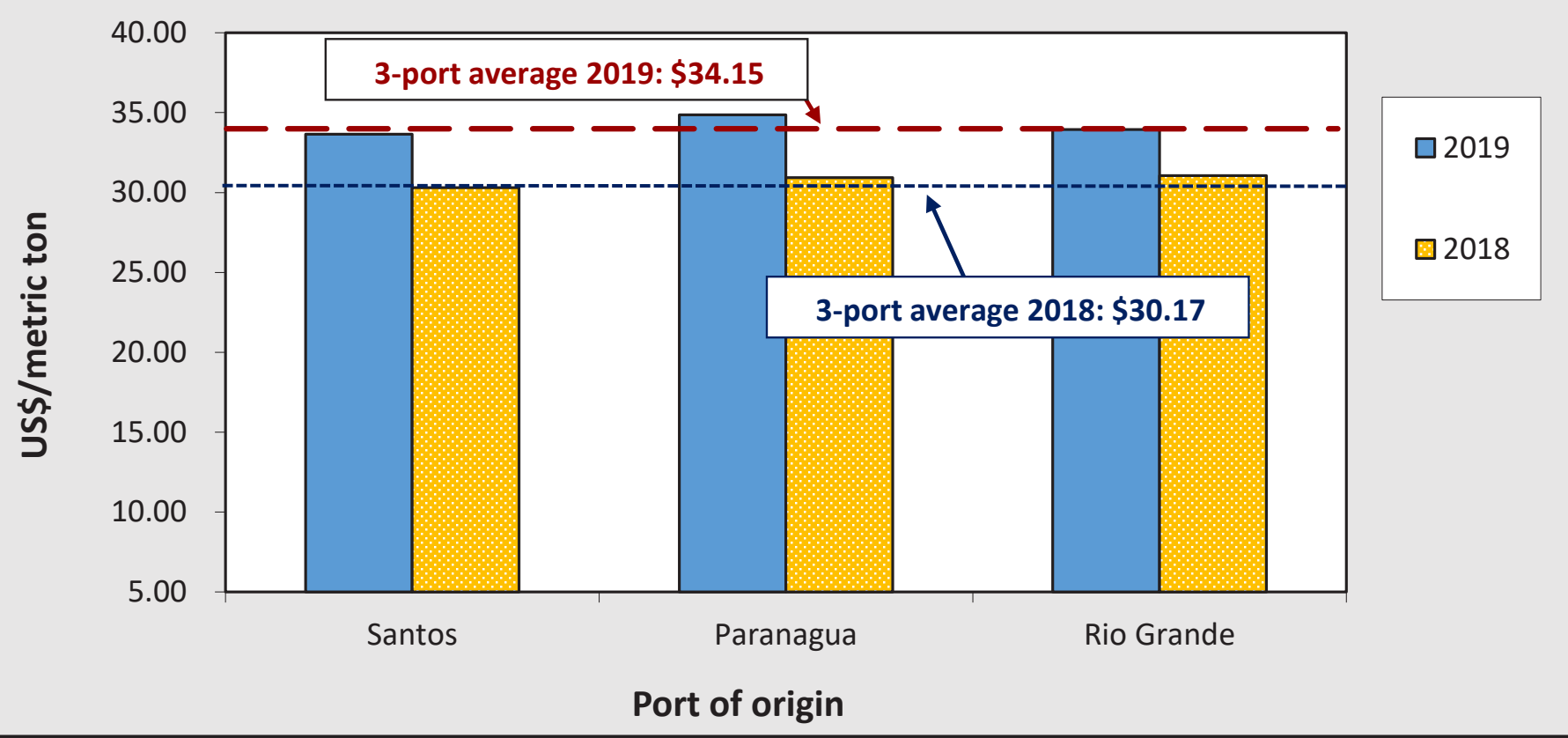

Source: University of São Paulo, Escola Superior de Agricultura "Luiz de Queiroz," Brazil (ESALQ/USP) and USDA, Agricultural Marketing Service. 
Farm prices measured in reais increased an average of 2.4 percent, from $R \$ 1,148.12 / \mathrm{mt}$ in 2018 to $\mathrm{R} \$ 1,175.84 / \mathrm{mt}$ in 2019. Rio Grande do Sul, Mato Grosso, Goiás, Paraná, Piauí, and Pará farm prices increased 1-7 percent, while Maranhão farm prices decreased 2 percent. However, when year-to-year farm prices were measured in U.S. dollars, the percentage decrease was greater than when measured in reais. The difference was partially due to a nearly 7 percent fall in value of the Brazilian real against the U.S. dollar.

\section{Selected Brazilian farm prices, reais/metric ton, 2018-19}

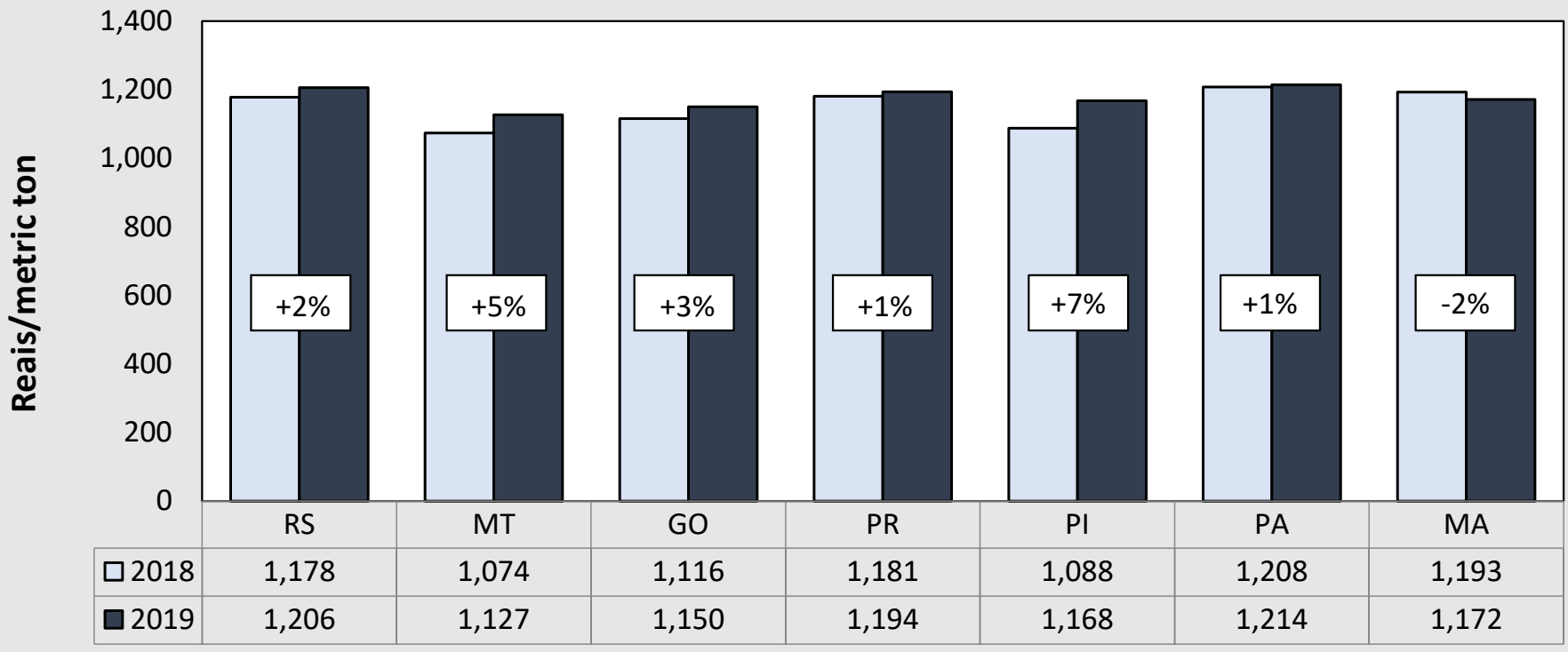

Note: $\mathrm{RS}=$ Rio Grande do Sul, MT = Mato Grosso, GO = Goiás, PR = Paraná, PI = Piauí, PA = Pará, and MA = Maranhão.

Source: Companhia Nacional de Abastecimento (CONAB).

Selected Brazilian farm prices, US\$/metric ton, 2018-19

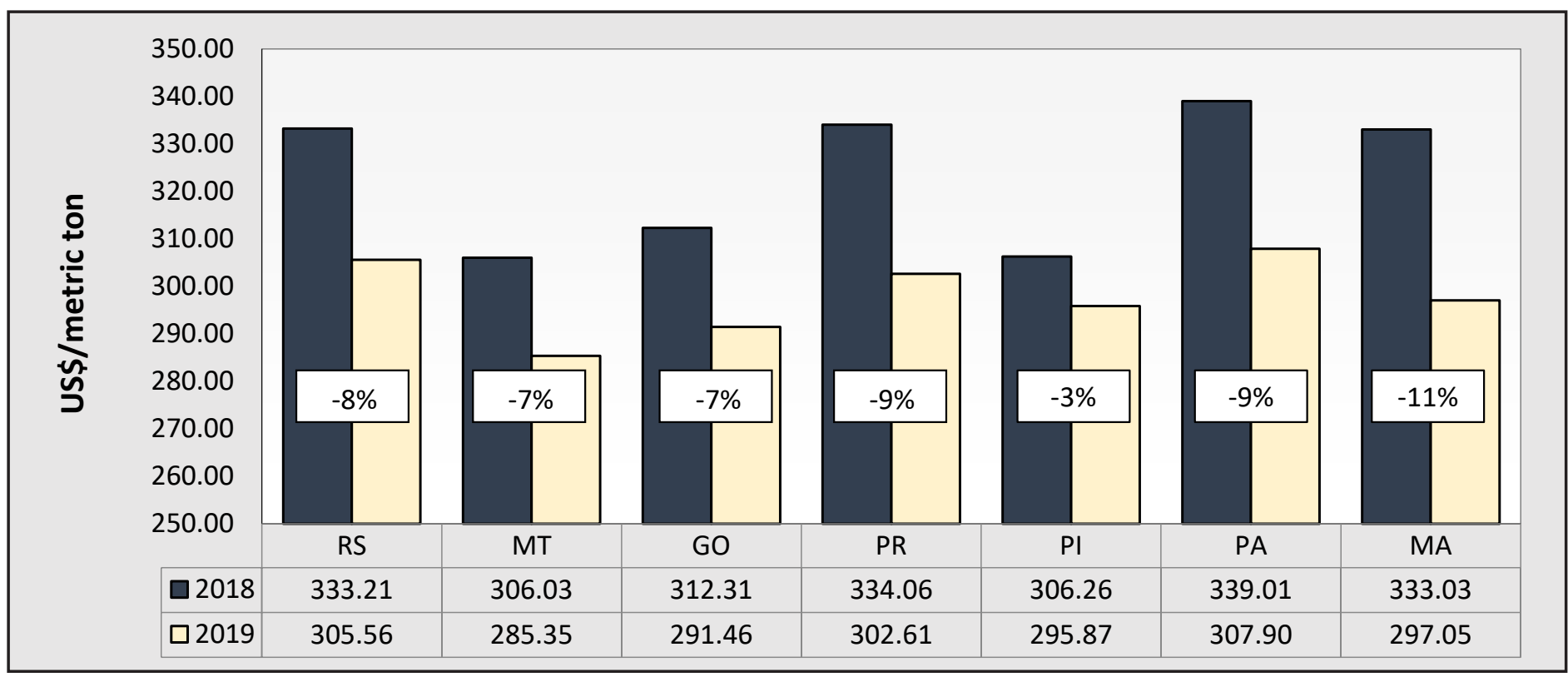

Note: RS = Rio Grande do Sul, MT = Mato Grosso, GO = Goiás, PR = Paraná, PI = Piauí, PA = Pará, and MA = Maranhão.

Source: Companhia Nacional de Abastecimento (CONAB). 
From 2018 to 2019, the Brazilian real depreciated nearly 7 percent against the U.S. dollar, from R\$3.69 per U.S. dollar to R\$3.94 per U.S. dollar.

Average quarterly exchange rate, real per U.S. dollar, 2017-19

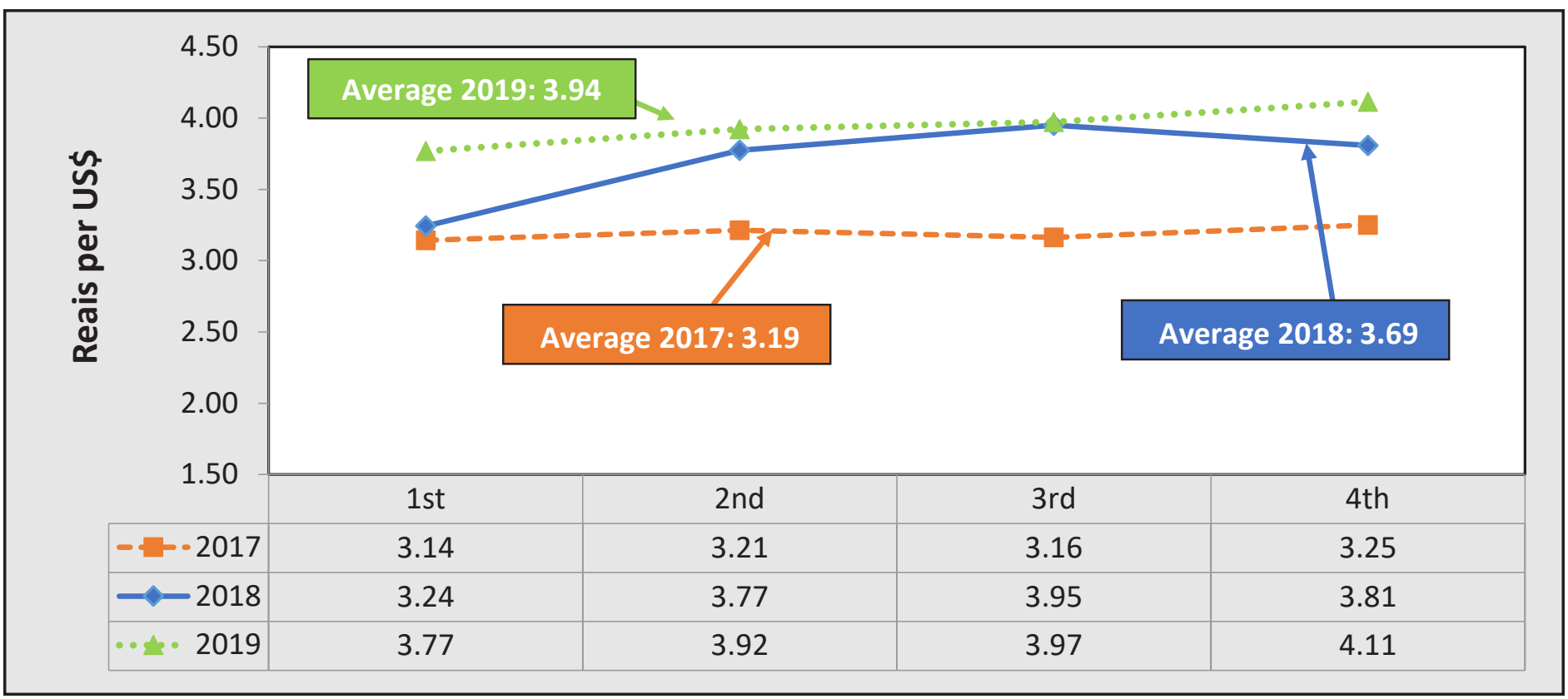

Source: Banco Central do Brasil

The 2019 Confederação Nacional do Transporte (CNT) survey of the overall highway conditions in Brazil estimates that, because of the poor conditions of the paved roads, the 2019 marginal operational cost of cargo trucks was 28.5 percent higher than it would have been if the trucks had used only paved roads in optimal condition. Overall, the 2019 additional operational cargo cost ( 28.5 percent) was higher than 2018 (26.7 percent). This cost declined only in the North. For example, according to CNT, if the cost of shipping a metric ton of soybeans from Sorriso, North MT, to Santos was $\$ 100$ per metric ton (mt), the 2019 optimal cost should have been $\$ 71.50 / \mathrm{mt}$.

Cost increases due to poor road pavement conditions, 2017-19

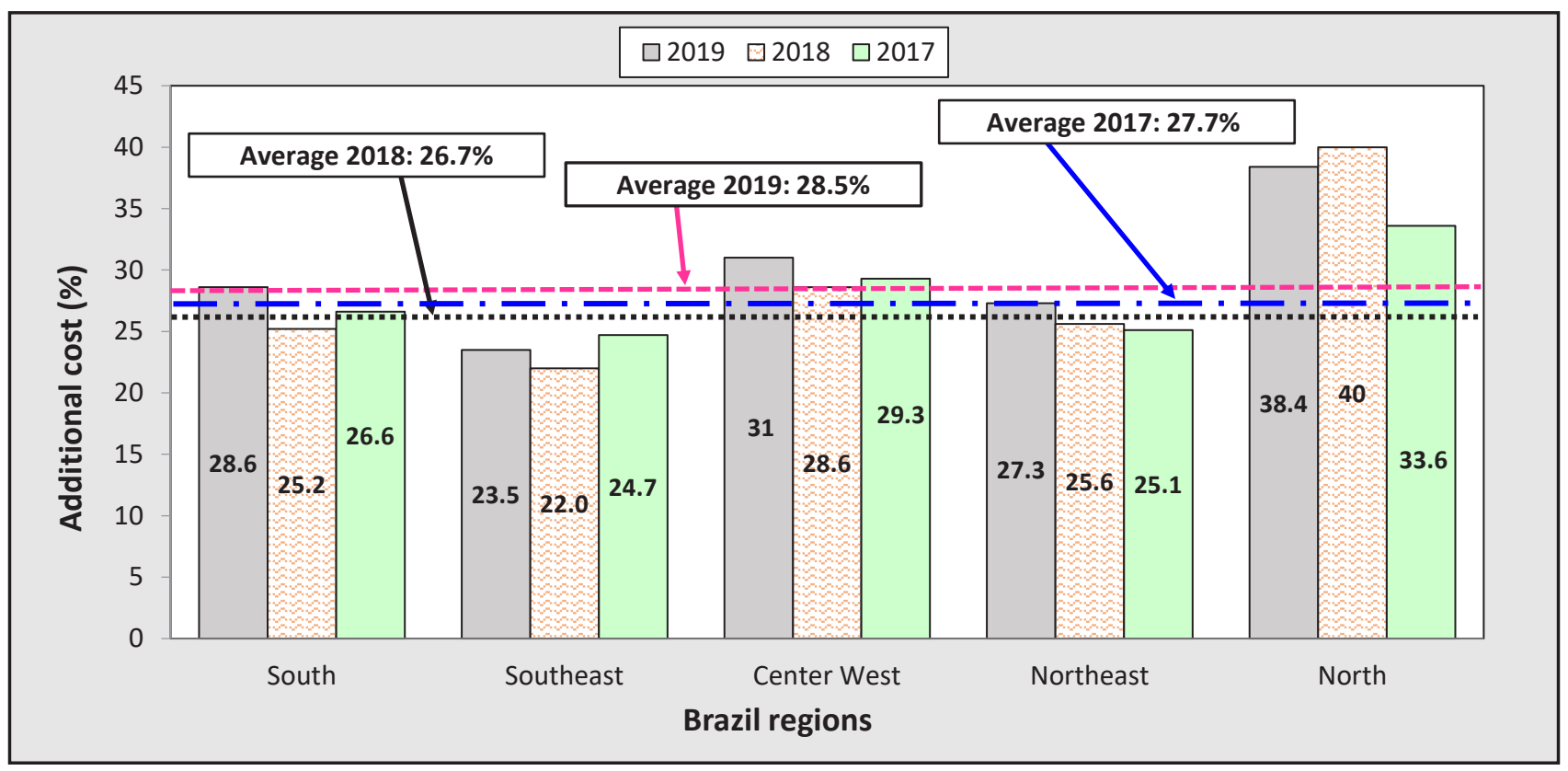

Source: Confederação Nacional do Transporte (CNT). 


\section{Brazilian Minimum Freight Rates Law Update}

On January 16, 2020, Brazil's National Land Transportation Agency's (ANTT) published updated guidelines to the National Policy of Minimum Freight Rates Law for truck cargo transportation. ${ }^{3}$

1. Shippers are obligated to pay backhaul freight rates for the return of empty containers. Shippers must also pay backhaul freight rates for trucks in specific fleets that cannot legally carry backhaul cargo, such as a truck that carries fuel or gases and cannot return with another type cargo.

2. The truck driver's daily rate (salary and expenses for lodging and food) is included in the calculation of the minimum rate.

3. Pressurized cargo-such as carbon dioxide, nitrogen, and oxygen gases utilized in the food industry-have been added as a new type of cargo covered by the law.

4. Two new tables were created for high efficiency loading operations that take less time to load and unload, thereby reducing the waiting time for trucks and drivers.

5. The costs of items included in the table (such as tires and maintenance) are to be updated every 6 months.

Current status: The Brazilian Supreme Court held several conciliation hearings about the constitutionality of the law. Conciliation hearings are suspended because of the COVID-19 pandemic. A new date will be appointed in due time.

Background: On August 9, 2018, the National Policy of Minimum Freight Rates Law was enacted to end an 11-day nationwide strike in late May by the truck drivers who blocked highways, creating immediate shortages of critical products such as fuel, food, and medicines. The poultry and pork industries were hit especially hard (USDA, FAS, Gain Report BR1810). Shortages of fuel and animal feed affected farms and feedlots. Slaughterhouses idled their production lines when transportation to the ports was cut off and their refrigerated warehouses reached full capacity (USDA, FAS, Gain Report BR1810). Soybean exports were not significantly affected for the limited duration of the strike. The law allows ANTT to set minimum freight rates for trucking nationwide, reflecting total operating costs based on fuel costs, distances, tolls, and other factors (Confederação Nacional do Transporte (CNT) and AgriCensus). The minimum freight rates include a charge on backhaul trips, even if the truck is empty. Truckers are forbidden to negotiate contracts below the ANTT minimum. The law requires freight rates to be equal to, or above, the minimum rates set by the ANTT. Rates are published twice a year, on January 20 and July $20 .{ }^{4}$ The minimum freight rates are adjusted every 6 months, based on several criteria, including fuel prices, inflation, and the cost of operations for independent drivers. Since 2018, organizations opposing these minimum mandatory freight rates have challenged the constitutionality of the law before the Brazil's Supreme Court.

3 On January 1, 2019, ANTT and the Fundação de Estudos Agrários Luiz de Queiroz (FEALQ) signed a 21-month contract to update the methodology and the minimum freight rate table.

4 The frequency with which freight rates will be published will change if the price of diesel fluctuates more than 10 percent from the set minimum price (USDA, FAS, Gain Report BR1812). If the freight rates are not published within the identified timeframe, the previous period's freight ratesupdated by the National Consumer Price Index (IPCA)-will be valid. 
On February 1, 2019, the Brazilian government announced the infrastructure priorities for President Bolsonaro's Administration ( $\underline{\text { ANTT }}$ and $\underline{\text { CNT)}}$ :

1. The North-South (EF-151) Railroad: Porto National, Tocantins-Estrela d'Oeste, São Paulo. This railroad integrates four States: Tocantins, Goiás, Minas Gerais, and São Paulo with access to the northeastern port of Itaquí-Sâo Luis, Maranhão, and the southern port of Santos with an extension that is 955 miles $(1,537 \mathrm{~km})$ long.

Current Status: On August 8, 2019, Rumo S.A. signed the 30-year concession contract for Ferrovia Norte-Sul (North-South Railway) from Estrela d'Oeste to Porto Nacional. Rumo has 2 years to complete the 424 miles ( $682 \mathrm{~km}$ ) between Anápolis and Estrela d'Oeste (95 percent completed) and start operations in 2021.

2. The West-East Integration (FIOL) Railroad (EF-334): Ilhéus, Bahia to Figueirópolis, Tocantins. Extension: 947 miles $(1,537 \mathrm{~km})$.

Current Status: The Brazilian government announced that Valec Engenharia, Construções e Ferrovias S.A. in partnership with the Army Engineering Construction Battalion will build the railroad.

3. Ferrogrão Railroad (EF-170) Railroad: The purpose is to consolidate the new Brazilian export rail corridor of the "Arco Norte" by connecting the grain-producing region of the Midwest to the State of Pará, ending at Miritituba Port. The EF-170 is expected to increase transport capacity and competitiveness within the corridor and alleviate traffic conditions on highway BR-163 by serving as an alternative route for soybean and corn exports. The estimated cost of the project is $\$ 2.5$ billion (R\$14 billion). ${ }^{5}$ The concession is for 65 years. Public hearings and technical studies are complete.

Current status: The Brazilian government announced that the auction for the construction and operation of the railroad will be held in the first semester of 2021.

4. BR-163: The distance by truck of 663 miles $(1,067 \mathrm{~km})$ via BR-163-from Sorriso, North Mato Grosso, (Brazil's largest grain producer) to Miritituba-is completed. Currently, it takes about 2 days to ship grain to Miritituba. There are reports of road deterioration (Portosenavios).

Current status: The Brazilian government announced that the auction to privatize BR-163 operations will be held in 2022. The concession is for 10 years. 
The Brazilian Government plans to change the current cargo transportation matrix by developing an integrated intermodal system. The intention is to increase railway shipments from 21 percent to 35 percent and waterway shipments from 14 percent to 29 percent. Truck shipments will be reduced from 61 percent to 30 percent.

\section{Brazil Modal share for general cargo, 2019-25}

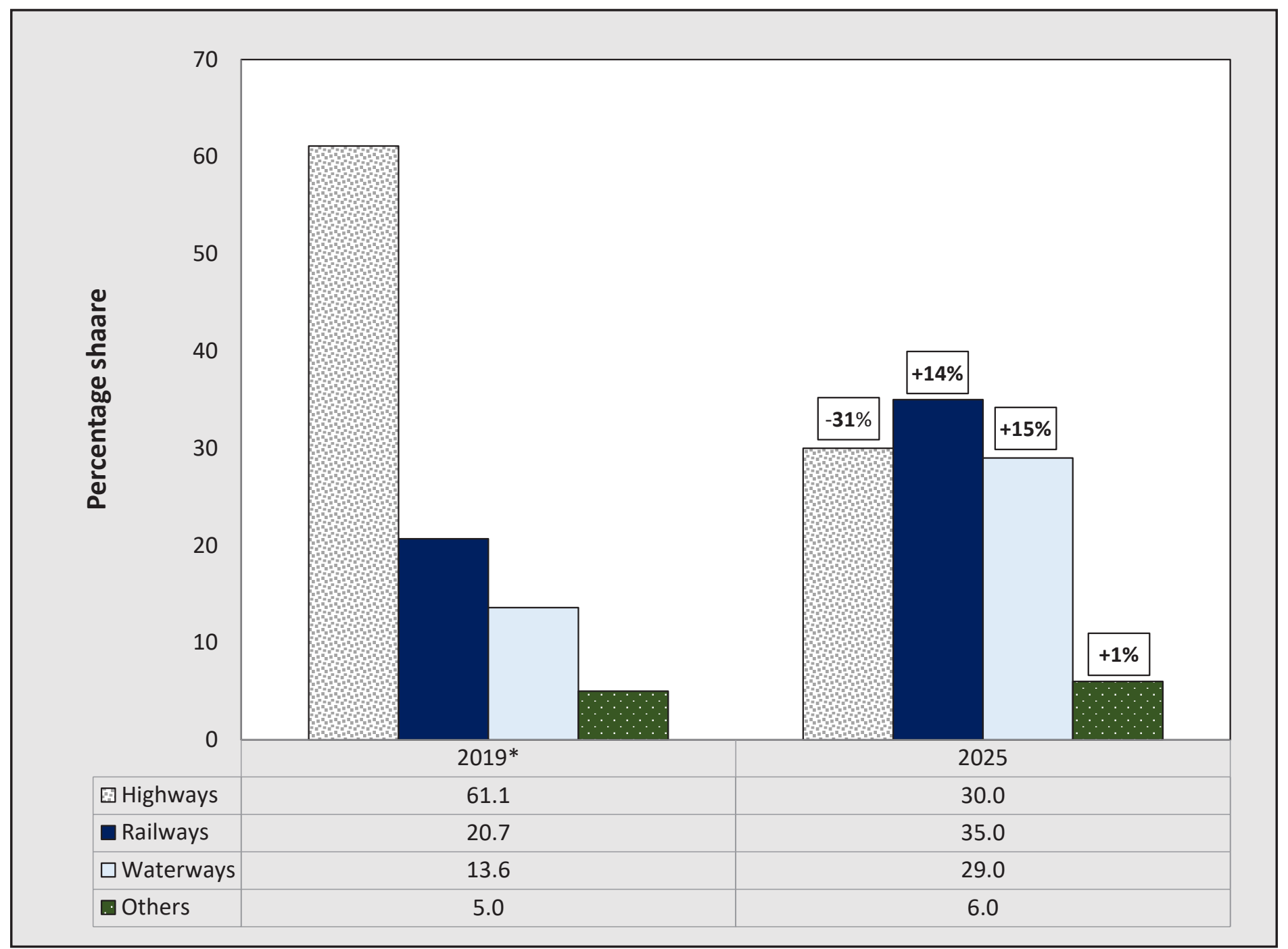

*Because of rounding, 2019 shares do not sum exactly to 100.

Source: Brazil Ministry of Transportation, National Plan of Logistic \& Transportation (PNLT) and Confederação Nacional do Transporte (CNT) 2019. 


\section{TRANSPORTATION INDICATORS}

\section{Quarterly costs of transporting Brazilian soybeans from the southern ports to Shanghai, China}

\begin{tabular}{|c|c|c|c|c|c|c|c|c|c|c|}
\hline & \multicolumn{10}{|c|}{2019} \\
\hline & 1st qtr & 2nd qtr & $3 r d q t r$ & 4th qtr & Avg & 1st qtr & 2nd qtr & $3 r d$ qtr & 4th qtr & Avg \\
\hline & \multicolumn{5}{|c|}{$\begin{array}{c}\text { North } \mathrm{MT}^{1} \text { - Santos }{ }^{2} \text { by truck } \\
\text {-US\$ } \$ \mathrm{mt}-\end{array}$} & \multicolumn{5}{|c|}{$\begin{array}{c}\text { North } \mathrm{MT}^{1} \text { - Paranaguá } \\
-\mathrm{US} \$ \mathbf{m t}-\end{array}$} \\
\hline Truck & 81.92 & 73.96 & 88.37 & 72.86 & 79.28 & 71.05 & 72.82 & 87.49 & 71.77 & 75.78 \\
\hline Ocean & 32.25 & 30.92 & 33.25 & 38.17 & 33.65 & 33.75 & 31.42 & 34.75 & 39.50 & 34.86 \\
\hline Total transportation & 114.17 & 104.88 & 121.62 & 111.03 & 112.92 & 104.80 & 104.24 & 122.24 & 111.27 & 110.64 \\
\hline Farm gate price ${ }^{3}$ & 275.38 & 271.70 & 286.87 & 307.47 & 285.35 & 275.38 & 271.70 & 286.87 & 307.47 & 285.35 \\
\hline Landed cost & 389.54 & 376.58 & 408.48 & 418.50 & 398.28 & 380.18 & 375.94 & 409.10 & 418.74 & 395.99 \\
\hline \multirow[t]{2}{*}{ Transport $\%$ of landed cost } & 29.3 & 27.8 & 29.8 & 26.5 & 28.4 & 27.6 & 27.7 & 29.9 & 26.6 & 27.9 \\
\hline & \multicolumn{5}{|c|}{$\begin{array}{c}\text { North } \mathrm{MT}^{1} \text { - Santos }{ }^{2} \text { by truck and rail } \\
\text {-US\$/mt- }\end{array}$} & \multicolumn{5}{|c|}{$\begin{array}{c}\text { Northwest RS }{ }^{1} \text { - Rio Grande }{ }^{2} \\
\text {-US\$/mt- }\end{array}$} \\
\hline Truck & 29.89 & 26.49 & 30.03 & 24.07 & 27.62 & 26.05 & 24.86 & 26.82 & 22.50 & 25.06 \\
\hline Rail $^{4}$ & 41.21 & 31.39 & 48.04 & 39.28 & 39.98 & - & - & - & - & - \\
\hline Ocean & 32.25 & 30.92 & 33.25 & 38.17 & 33.65 & 31.58 & 30.25 & 34.25 & 39.67 & 33.94 \\
\hline Total transportation & 103.36 & 88.80 & 111.32 & 101.53 & 101.25 & 57.63 & 55.11 & 61.07 & 62.17 & 58.99 \\
\hline Farm gate price ${ }^{3}$ & 275.38 & 271.70 & 286.87 & 307.47 & 285.35 & 308.52 & 294.72 & 304.20 & 314.81 & 305.56 \\
\hline Landed cost & 378.73 & 360.50 & 398.19 & 409.00 & 386.60 & 366.2 & 349.83 & 365.27 & 376.98 & 364.56 \\
\hline Transport \% of landed cost & 27.3 & 24.6 & 28.0 & 24.8 & 26.2 & 15.7 & 15.8 & 16.7 & 16.5 & 16.2 \\
\hline
\end{tabular}

${ }^{1}$ Producing regions: RS = Rio Grande do Sul and MT= Mato Grosso.

${ }^{2}$ Export port.

${ }^{3}$ The source of the farm gate price is the Brazilian Government, Companhia Nacional de Abastecimento (CONAB).

${ }^{4}$ In Brazil, there are no public/official rail tariff rates. Rail rates can be up to 30 percent lower than truck rates, depending on the volumes hauled and the terms of contracts signed between the railroad company and shippers.

Note: qtr. = quarter. $\mathrm{mt}=$ metric ton. Avg = average.

Source: University of São Paulo, Escola Superior de Agricultura "Luiz de Queiroz," Brazil (ESALQ/USP) and USDA, Agricultural Marketing Service. 


\section{Quarterly costs of transporting Brazilian soybeans from the southern ports to Hamburg, Germany}

\begin{tabular}{|c|c|c|c|c|c|c|c|c|c|c|}
\hline & \multicolumn{10}{|c|}{2019} \\
\hline & 1st qtr & 2nd qtr & $3 r d q t r$ & 4th qtr & Avg & 1st qtr & 2nd qtr & $3 r d$ qtr & 4th qtr & Avg \\
\hline & \multicolumn{5}{|c|}{$\begin{array}{c}\text { North } \mathrm{MT}^{1} \text { - Santos }{ }^{2} \text { by truck } \\
\text {-US\$/mt- }\end{array}$} & \multicolumn{5}{|c|}{$\begin{array}{c}\text { North } \mathrm{MT}^{1} \text { - Paranaguá }{ }^{2} \\
-\mathrm{US} \$ \mathrm{mt}-\end{array}$} \\
\hline Truck & 81.92 & 73.96 & 88.37 & 72.86 & 79.28 & 71.05 & 72.82 & 87.49 & 71.77 & 75.78 \\
\hline Ocean & 23.00 & 21.50 & 27.00 & 31.00 & 25.63 & 23.00 & 21.25 & 27.00 & 30.75 & 25.50 \\
\hline Total transportation & 104.92 & 95.46 & 115.37 & 103.86 & 104.90 & 94.05 & 94.07 & 114.49 & 102.52 & 101.28 \\
\hline Farm gate price ${ }^{3}$ & 275.38 & 271.70 & 286.87 & 307.47 & 285.35 & 275.38 & 271.70 & 286.87 & 307.47 & 285.35 \\
\hline Landed cost & 380.29 & 367.16 & 402.23 & 411.33 & 390.25 & 369.43 & 365.77 & 401.35 & 409.99 & 386.64 \\
\hline \multirow[t]{2}{*}{ Transport $\%$ of landed cost } & 27.6 & 26.0 & 28.7 & 25.2 & 26.9 & 25.5 & 25.7 & 28.5 & 25.0 & 26.2 \\
\hline & \multicolumn{5}{|c|}{$\begin{array}{l}\text { North } \mathrm{MT}^{1} \text { - Santos }{ }^{2} \text { by truck and rail } \\
- \text { US\$/mt- }\end{array}$} & \multicolumn{5}{|c|}{$\begin{array}{c}\text { Northwest RS }{ }^{1} \text { - Rio Grande }{ }^{2} \\
\text {-US\$/mt- }\end{array}$} \\
\hline Truck & 29.89 & 26.49 & 30.03 & 24.07 & 27.62 & 26.05 & 24.86 & 26.82 & 22.50 & 25.06 \\
\hline Rail $^{4}$ & 41.21 & 31.39 & 48.04 & 39.28 & 39.98 & - & - & - & - & - \\
\hline Ocean & 23.00 & 21.50 & 27.00 & 31.00 & 25.63 & 23.00 & 21.25 & 27.00 & 31.25 & 25.63 \\
\hline Total transportation & 94.11 & 79.38 & 105.07 & 94.36 & 93.23 & 49.05 & 46.11 & 53.82 & 53.75 & 50.68 \\
\hline Farm gate price ${ }^{3}$ & 275.38 & 271.70 & 286.87 & 307.47 & 285.35 & 308.52 & 294.72 & 304.20 & 314.81 & 305.56 \\
\hline Landed cost & 369.48 & 351.08 & 391.94 & 401.83 & 378.58 & 357.57 & 340.83 & 358.02 & 368.56 & 356.25 \\
\hline Transport \% of landed cost & 25.5 & 22.6 & 26.8 & 23.5 & 24.6 & 13.7 & 13.5 & 15.0 & 14.6 & 14.2 \\
\hline
\end{tabular}

${ }^{1}$ Producing regions: RS = Rio Grande do Sul and MT= Mato Grosso.

${ }^{2}$ Export port.

${ }^{3}$ The source of the farm gate price is the Brazilian Government, Companhia Nacional de Abastecimento (CONAB).

${ }^{4}$ In Brazil, there are no public/official rail tariff rates. Rail rates can be up to 30 percent lower than truck rates, depending on the volumes hauled and the terms of contracts signed between the railroad company and shippers.

Note: qtr. = quarter. $\mathrm{mt}=$ metric ton. Avg = average.

Source: University of São Paulo, Escola Superior de Agricultura “Luiz de Queiroz," Brazil (ESALQ/USP) and USDA, Agricultural Marketing Service. 


\section{Quarterly costs of transporting Brazilian soybeans from the northern and northeastern ports to Shanghai, China}

\begin{tabular}{|c|c|c|c|c|c|c|c|c|c|c|}
\hline & \multicolumn{10}{|c|}{2019} \\
\hline & 1st qtr & 2nd qtr & 3rd qtr & 4th qtr & Avg & 1st qtr & 2nd qtr & 3rd qtr & 4th qtr & Avg \\
\hline & \multicolumn{5}{|c|}{$\begin{array}{c}\text { North } \mathrm{MT}^{1} \text { - Santarém }{ }^{2} \\
\text {-US\$/mt- }\end{array}$} & \multicolumn{5}{|c|}{$\begin{array}{c}\text { South MA }{ }^{1} \text { - São Luís }{ }^{2} \\
\text {-US\$/mt- }\end{array}$} \\
\hline Truck & 59.40 & 47.34 & 55.66 & 45.74 & 52.04 & 37.04 & 31.80 & 36.22 & 26.89 & 32.99 \\
\hline Ocean & 32.25 & 30.58 & 38.25 & 39.17 & 35.06 & 31.00 & 30.58 & 38.25 & 39.42 & 34.81 \\
\hline Total transportation & 91.65 & 77.92 & 93.91 & 84.91 & 87.10 & 68.04 & 62.38 & 74.47 & 66.31 & 67.80 \\
\hline Farm gate price ${ }^{3}$ & 275.38 & 271.70 & 286.87 & 307.47 & 285.35 & 298.43 & 278.70 & 300.20 & 310.87 & 297.05 \\
\hline Landed cost & 367.03 & 349.62 & 380.78 & 392.39 & 372.45 & 366.47 & 341.08 & 374.67 & 377.18 & 364.85 \\
\hline \multirow[t]{2}{*}{ Transport $\%$ of landed cost } & 25.0 & 22.3 & 24.7 & 21.6 & 23.4 & 18.6 & 18.3 & 19.9 & 17.6 & 18.6 \\
\hline & \multicolumn{5}{|c|}{$\begin{array}{c}\text { Southwest } \mathrm{PI}^{1} \text { - São Luís } \\
\text {-US\$/mt- }\end{array}$} & \multicolumn{5}{|c|}{$\begin{array}{c}\text { North } \mathrm{MT}^{1} \text { - Barcarena }{ }^{2} \\
\text {-US\$/mt- }\end{array}$} \\
\hline Truck & 45.24 & 38.41 & 41.42 & 32.28 & 39.34 & 53.99 & 45.66 & 49.49 & 37.43 & 46.64 \\
\hline Barge $^{4}$ & - & - & - & - & - & 19.66 & 18.30 & 20.63 & 16.79 & 18.85 \\
\hline Ocean & 31.00 & 30.58 & 38.25 & 39.42 & 34.81 & 32.25 & 29.92 & 38.25 & 39.42 & 34.96 \\
\hline Total transportation & 76.24 & 68.99 & 79.67 & 71.70 & 74.15 & 105.90 & 93.89 & 108.37 & 93.64 & 100.45 \\
\hline Farm gate price ${ }^{3}$ & 292.96 & 285.28 & 288.35 & 316.88 & 295.87 & 275.38 & 271.70 & 286.87 & 307.47 & 285.35 \\
\hline Landed cost & 369.20 & 354.27 & 368.03 & 388.58 & 370.02 & 381.28 & 365.59 & 395.24 & 401.11 & 385.80 \\
\hline Transport $\%$ of landed cost & 20.7 & 19.5 & 21.6 & 21.6 & 20.9 & 27.8 & 25.7 & 27.4 & 23.3 & 26.1 \\
\hline
\end{tabular}

${ }^{1}$ Producing regions: $\mathrm{MT}=$ Mato Grosso, $\mathrm{PI}=$ Piauí, and MA = Maranhão.

${ }^{2}$ Export port.

${ }^{3}$ The source of the farm gate price is the Brazilian Government, Companhia Nacional de Abastecimento (CONAB).

${ }^{4}$ In Brazil, there are no public/official barge rates. Barge rates can be up to 60 percent lower than truck rates, depending on the volumes hauled and the terms of contracts signed between the barge company and shippers. The distance is in nautical miles.

Note: qtr. = quarter. $\mathrm{mt}=$ metric ton. Avg = average.

Source: University of São Paulo, Escola Superior de Agricultura "Luiz de Queiroz," Brazil (ESALQ/USP) and USDA, Agricultural Marketing Service. 


\section{Quarterly costs of transporting Brazilian soybeans from the northern and northeastern ports to Hamburg, Germany}

\begin{tabular}{|c|c|c|c|c|c|c|c|c|c|c|}
\hline & \multicolumn{10}{|c|}{2019} \\
\hline & 1st qtr & 2nd qtr & $3 r d$ qtr & 4th qtr & Avg & 1st qtr & 2nd qtr & $3 r d$ qtr & 4th qtr & Avg \\
\hline & \multicolumn{5}{|c|}{$\begin{array}{c}\text { North } \mathrm{MT}^{1} \text { - Santarém }{ }^{2} \\
\text {-US\$ } \$ \mathrm{mt}-\end{array}$} & \multicolumn{5}{|c|}{$\begin{array}{c}\text { South MA }{ }^{1} \text { - São Luís }{ }^{2} \\
\text {-US\$/mt- }\end{array}$} \\
\hline Truck & 59.40 & 47.34 & 55.66 & 45.74 & 52.04 & 37.04 & 31.80 & 36.22 & 26.89 & 32.99 \\
\hline Ocean & 21.00 & 20.25 & 25.92 & 26.50 & 23.42 & 18.00 & 17.10 & 22.77 & 23.50 & 20.34 \\
\hline Total transportation & 80.40 & 67.59 & 81.58 & 72.24 & 75.45 & 55.04 & 48.90 & 58.99 & 50.39 & 53.33 \\
\hline Farm gate price ${ }^{3}$ & 275.38 & 271.70 & 286.87 & 307.47 & 285.35 & 298.43 & 278.70 & 300.20 & 310.87 & 297.05 \\
\hline Landed cost & 355.78 & 339.29 & 368.45 & 379.72 & 360.81 & 353.47 & 327.60 & 359.19 & 361.26 & 350.38 \\
\hline \multirow[t]{2}{*}{ Transport $\%$ of landed cost } & 22.6 & 19.9 & 22.1 & 19.0 & 20.9 & 15.6 & 14.9 & 16.4 & 13.9 & 15.2 \\
\hline & \multicolumn{5}{|c|}{$\begin{array}{c}\text { Southwest } \mathrm{PI}^{1} \text { - São Luís } \\
\text {-US\$/mt- }\end{array}$} & \multicolumn{5}{|c|}{$\begin{array}{c}\text { North } \mathrm{MT}^{1} \text { - Barcarena }{ }^{2} \\
\text {-US\$/mt- }\end{array}$} \\
\hline Truck & 45.24 & 38.41 & 41.42 & 32.28 & 39.34 & 53.99 & 45.66 & 49.49 & 37.43 & 46.64 \\
\hline Barge $^{4}$ & - & - & - & - & - & 19.66 & 18.30 & 20.63 & 16.79 & 18.85 \\
\hline Ocean & 18.00 & 17.10 & 22.77 & 23.50 & 20.34 & 19.00 & 17.85 & 23.52 & 24.25 & 21.16 \\
\hline Total transportation & 63.24 & 55.51 & 64.19 & 55.78 & 59.68 & 92.65 & 81.82 & 93.64 & 78.47 & 86.64 \\
\hline Farm gate price ${ }^{3}$ & 292.96 & 285.28 & 288.35 & 316.88 & 295.87 & 275.38 & 271.70 & 286.87 & 307.47 & 285.35 \\
\hline Landed cost & 356.20 & 340.79 & 352.55 & 372.66 & 355.55 & 368.03 & 353.52 & 380.51 & 385.94 & 372.00 \\
\hline Transport \% of landed cost & 17.8 & 16.3 & 18.2 & 15.0 & 16.8 & 25.2 & 23.1 & 24.6 & 20.3 & 23.3 \\
\hline
\end{tabular}

${ }^{1}$ Producing regions: $\mathrm{MT}=$ Mato Grosso, $\mathrm{PI}=$ Piauí, and MA = Maranhão.

${ }^{2}$ Export port.

${ }^{3}$ The source of the farm gate price is the Brazilian Government, Companhia Nacional de Abastecimento (CONAB).

${ }^{4}$ In Brazil, there are no public/official barge rates. Barge rates can be up to 60 percent lower than truck rates, depending on the volumes hauled and the terms of contracts signed between the barge company and shippers. The distance is in nautical miles.

Note: qtr. $=$ quarter $. \mathrm{mt}=$ metric ton. Avg = average.

Source: University of São Paulo, Escola Superior de Agricultura "Luiz de Queiroz," Brazil (ESALQ/USP) and USDA, Agricultural Marketing Service. 
Truck rates for selected Brazilian soybean export transportation routes, 2019

\begin{tabular}{|c|c|c|c|c|c|c|c|c|c|}
\hline \multirow{3}{*}{$\begin{array}{l}\text { Route } \\
\quad \#\end{array}$} & \multirow{3}{*}{$\begin{array}{l}\text { Origin }^{1} \\
\text { (reference city) }\end{array}$} & \multirow{3}{*}{ Destination } & \multirow{3}{*}{$\begin{array}{l}\text { Distance } \\
\text { (miles) }^{2}\end{array}$} & \multirow{3}{*}{$\begin{array}{c}\text { Share } \\
(\%)^{3}\end{array}$} & \multicolumn{5}{|c|}{ Freight Price (US\$) } \\
\hline & & & & & 1st qtr & 2nd qtr & $3 \mathrm{rd} \mathrm{qtr}$ & 4th qtr & Avg \\
\hline & & & & & \multicolumn{5}{|c|}{$\left(\right.$ per 100 miles $^{4}$} \\
\hline 1 & Northwest RS ${ }^{5}$ (Cruz Alta) & Rio Grande & 288 & 11.3 & 9.05 & 8.63 & 9.31 & 7.81 & 8.70 \\
\hline 2 & North MT (Sorriso) & Santos & 1,190 & 3.0 & 6.88 & 6.21 & 7.43 & 6.12 & 6.66 \\
\hline 3 & North MT (Sorriso) & Paranaguá & 1,262 & 2.9 & 5.63 & 5.77 & 6.93 & 5.69 & 6.00 \\
\hline 4 & South GO (Rio Verde) & Santos & 587 & 4.8 & 7.29 & 5.89 & 6.75 & 5.51 & 6.36 \\
\hline 5 & South GO (Rio Verde) & Paranaguá & 726 & 3.9 & 6.15 & 6.03 & 7.06 & 5.81 & 6.26 \\
\hline 6 & North Central PR (Londrina) & Paranaguá & 268 & 3.2 & 8.86 & 8.40 & 9.06 & 7.47 & 8.45 \\
\hline 7 & Western Central PR (Mamborê) & Paranaguá & 311 & 2.4 & 7.96 & 7.76 & 8.48 & 7.11 & 7.83 \\
\hline 8 & Triangle MG (Uberaba) & Santos & 339 & 3.0 & 10.13 & 8.11 & 9.02 & 7.37 & 8.66 \\
\hline 9 & West PR (Assis Chateaubriand) & Paranaguá & 377 & 2.3 & 7.45 & 7.00 & 7.86 & 6.47 & 7.19 \\
\hline 10 & West Extreme BA (São Desidério) & Salvador & 535 & 6.6 & 7.03 & 6.48 & 7.41 & 6.02 & 6.74 \\
\hline 11 & Southeast MT (Primavera do Leste) & Santos & 901 & 2.4 & 6.23 & 5.60 & 6.61 & 5.34 & 5.94 \\
\hline 12 & Southeast MT (Primavera do Leste) & Paranaguá & 975 & 2.2 & 5.21 & 5.26 & 6.35 & 5.09 & 5.48 \\
\hline 13 & Southwest MS (Maracaju) & Paranaguá & 612 & 3.5 & 6.48 & 6.33 & 7.28 & 5.99 & 6.52 \\
\hline 14 & Southwest MS (Maracaju) & Santos & 652 & 3.2 & 7.67 & 6.20 & 7.21 & 5.90 & 6.75 \\
\hline 15 & West PR (Assis Chateaubriand) & Santos & 550 & 1.6 & 7.76 & 6.29 & 7.27 & 5.98 & 6.82 \\
\hline 16 & East GO (Cristalina) & Santos & 585 & 1.9 & 8.18 & 6.80 & 7.94 & 6.50 & 7.35 \\
\hline 17 & North PR (Cornélio Procópio) & Paranaguá & 306 & 1.8 & 7.16 & 6.78 & 7.24 & 5.92 & 6.78 \\
\hline 18 & Eastern Central PR (Castro) & Paranaguá & 130 & 2.0 & 12.15 & 10.87 & 11.15 & 9.18 & 10.84 \\
\hline 19 & South Central PR (Guarapuava) & Paranaguá & 204 & 2.3 & 11.22 & 10.29 & 11.06 & 9.07 & 10.41 \\
\hline 20 & $\begin{array}{c}\text { North Central MS } \\
\text { (São Gabriel do Oeste) }\end{array}$ & Santos & 720 & 2.4 & 6.79 & 5.44 & 6.29 & 5.17 & 5.92 \\
\hline 21 & Ribeirão Preto SP (Guairá) & Santos & 314 & 0.0 & 8.57 & 6.62 & 7.30 & 5.89 & 7.09 \\
\hline 22 & Northeast MT (Canarana) & Santos & 950 & 3.3 & 7.04 & 5.71 & 6.84 & 5.56 & 6.29 \\
\hline 23 & East MS (Chapadão do Sul) & Santos & 607 & 0.0 & 6.71 & 5.45 & 6.23 & 5.11 & 5.88 \\
\hline 24 & Northeast MT (Canarana) & Paranaguá & 1,075 & 2.9 & 6.04 & 5.66 & 6.66 & 5.54 & 5.97 \\
\hline 25 & Western Central RS (Tupanciretã) & Rio Grande & 273 & 2.5 & 9.40 & 8.31 & 8.47 & 6.91 & 8.27 \\
\hline 26 & Southwest PR (Chopinzinho) & Paranaguá & 291 & 1.7 & 11.75 & 10.44 & 11.81 & 7.48 & 10.37 \\
\hline 27 & North MT (Sorriso) & Itaituba & 672 & 5.4 & 8.04 & 6.80 & 7.37 & 5.57 & 6.94 \\
\hline 28 & North MT (Sorriso) & Porto Velho & 632 & 5.7 & 6.29 & 5.98 & 6.26 & 5.19 & 5.93 \\
\hline 29 & North MT (Sorriso) & Santarém & 876 & 4.1 & 6.78 & 5.40 & 6.35 & 5.22 & 5.94 \\
\hline 30 & South MA (Balsas) & São Luís & 482 & 2.1 & 7.69 & 6.60 & 7.52 & 5.58 & 6.85 \\
\hline 31 & Southwest PI (Bom Jesus) & São Luís & 606 & 2.6 & 7.47 & 6.34 & 6.84 & 5.33 & 6.49 \\
\hline 32 & Southeast PA (Paragominas) & Barcarena & 249 & 1.5 & 10.05 & 7.58 & 8.08 & 6.66 & 8.09 \\
\hline 33 & East TO (Campos Lindos) & São Luís & 842 & 1.6 & 6.43 & 5.36 & 6.68 & 5.54 & 6.00 \\
\hline & Weighted average & & 587 & 100.0 & 7.75 & 6.94 & 7.75 & 6.30 & 7.19 \\
\hline 34 & North MT (Sorriso) & $\begin{array}{l}\text { Rondonópolis } \\
\text { (Rail terminal) }\end{array}$ & 382 & & 7.83 & 6.93 & 7.86 & 6.30 & 7.23 \\
\hline 35 & Rondonópolis MT (Rail teminal) $^{6}$ & Santos & 1,019 & & 4.04 & 3.08 & 4.71 & 3.86 & 3.92 \\
\hline 36 & ${\text { Itaituba PA (Barge terminal) }{ }^{7}}^{7}$ & Santarém & 224 & & 9.24 & 7.84 & 5.15 & 3.93 & 6.54 \\
\hline 37 & Itaituba PA (Barge terminal) ${ }^{7}$ & Barcarena & 738 & & 2.67 & 2.48 & 2.80 & 2.28 & 2.55 \\
\hline
\end{tabular}

${ }^{1}$ Although each origin region comprises several cities, the main city is considered as a reference to establish the freight price; na = not available.

${ }^{2}$ Distance from the main city of the considered region to the mentioned ports.

${ }^{3}$ Share is measured as a percentage of total production.

${ }^{4}$ Average monthly exchange rate from "Banco Central do Brasil" was used to convert Brazilian reais to U.S. dollars.

${ }^{5} \mathrm{RS}=$ Rio Grande do Sul, MT= Mato Grosso, GO = Goiás, PR = Paraná, MG = Minas Gerais, BA = Bahia, MS = Mato Grosso do Sul, SP = São Paulo, PI =

Piauí, MA = Maranhão, $\mathrm{PA}=$ Pará, and TO = Tocantins.

${ }^{6}$ In Brazil, there are no public/official rail tariff rates. Rail rates can be up to 30 percent lower than truck rates, depending on the volumes hauled and the terms of contracts signed between the railroad company and shippers.

${ }^{7}$ In Brazil, there are no public/official barge rates. Barge rates can be up to 60 percent lower than truck rates, depending on the volumes hauled and the terms of contracts signed between the barge company and shippers. The distance is in nautical miles.

Note: qtr. $=$ quarter. $\mathrm{mt}=$ metric ton. Avg = average.

Source: University of São Paulo, Escola Superior de Agricultura "Luiz de Queiroz," Brazil (ESALQ/USP) and USDA, Agricultural Marketing Service. 
Brazilian soybean export increases and truck cost declines for selected routes, 2010-19

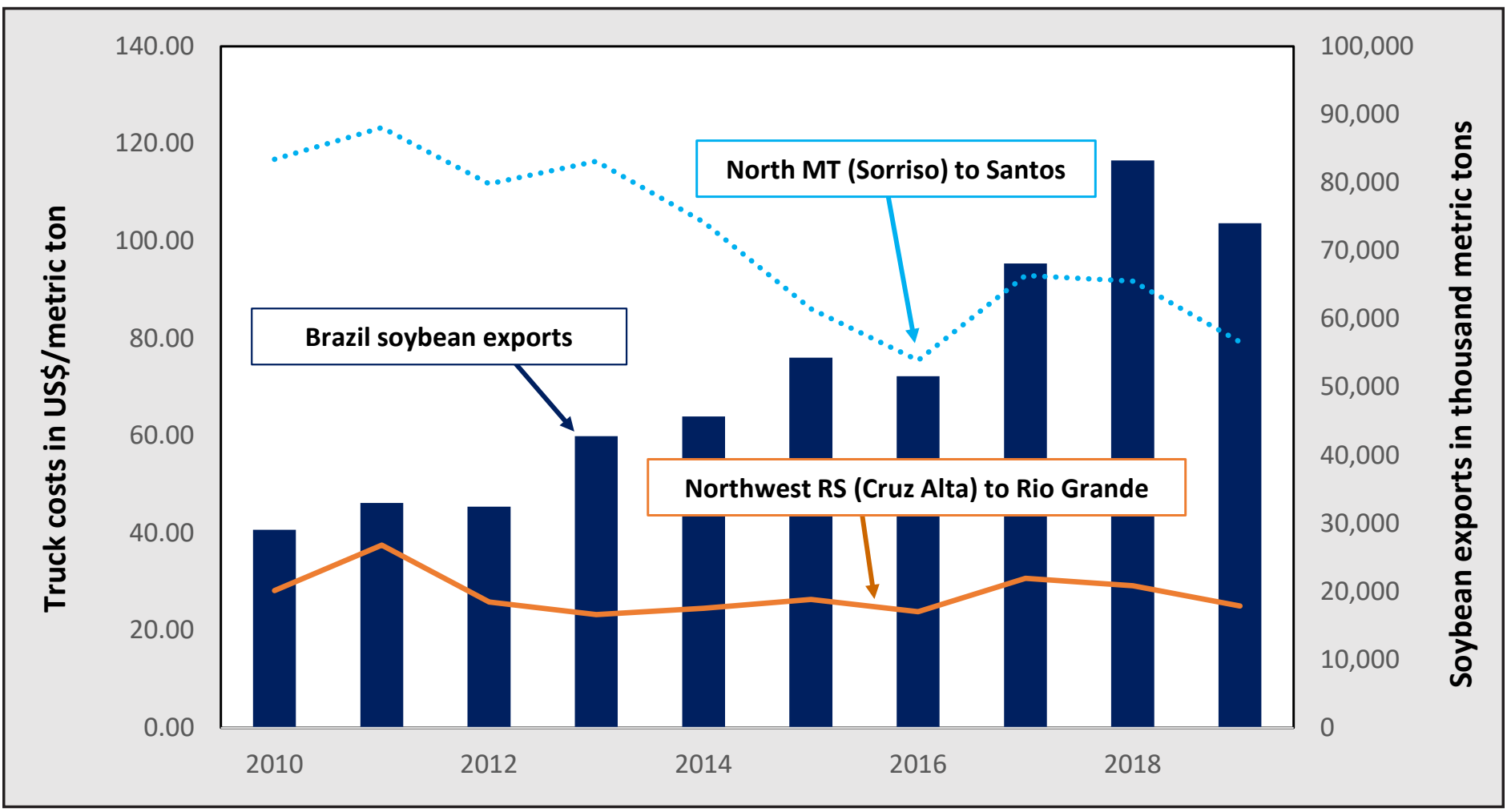

Note: $\mathrm{MT}=$ Mato Grosso and RG = Rio Grande do Sul.

Source: Comex Stat, Ministério da Indústria, Comércio Exterior e Serviços (MDIC), University of São Paulo, Escola Superior de Agricultura "Luiz de Queiroz," Brazil (ESALQ/USP) and USDA, Agricultural Marketing Service.

\section{Truck rates for selected southern Brazilian soybean export transportation routes, 2017-19}

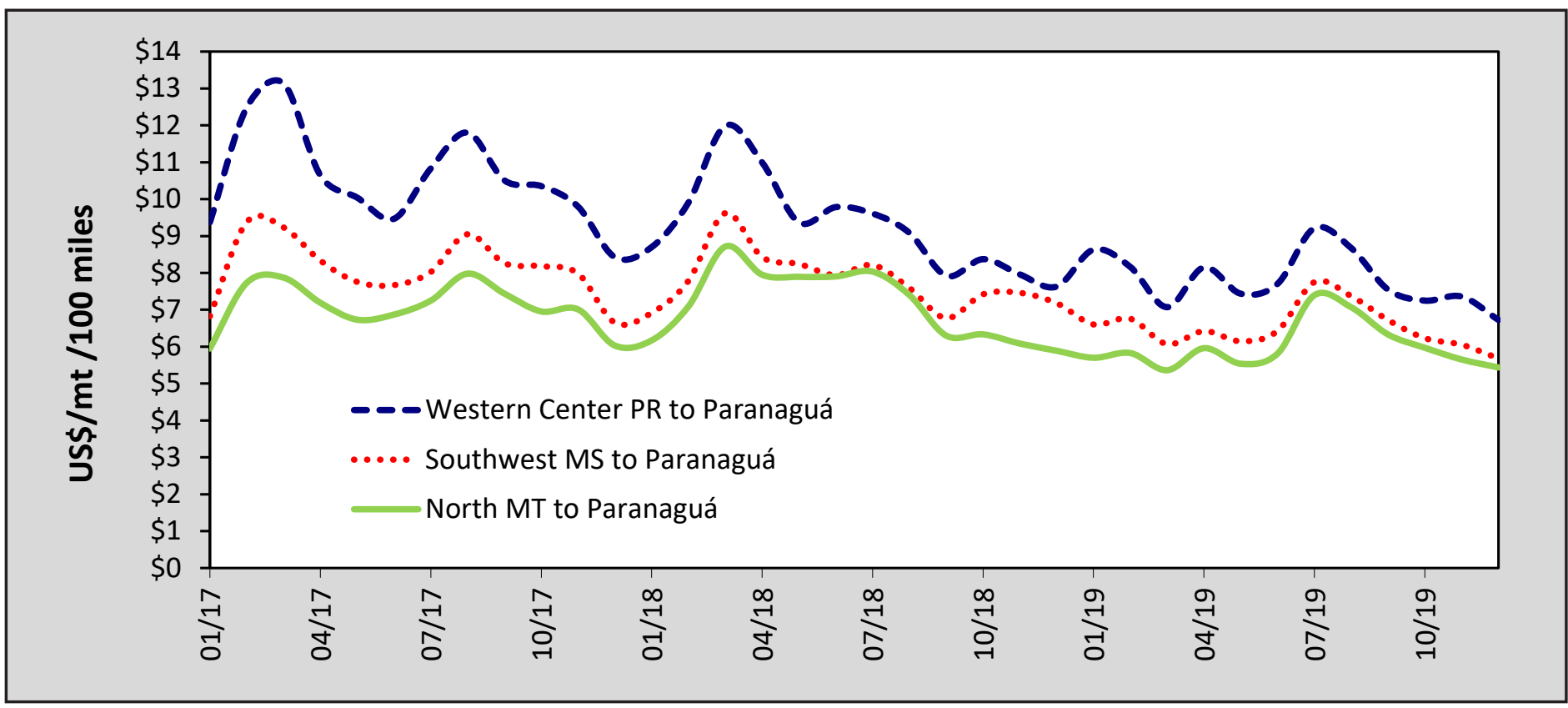

Note: $m t=$ metric ton. PR = Paraná, MT= Mato Grosso, and MS = Mato Grosso do Sul.

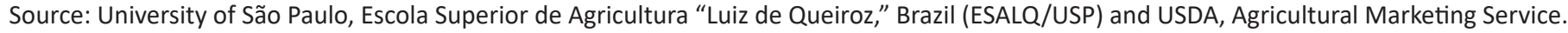


Truck rates for selected north, south, and northeastern Brazilian soybean export transportation routes, 2017-19

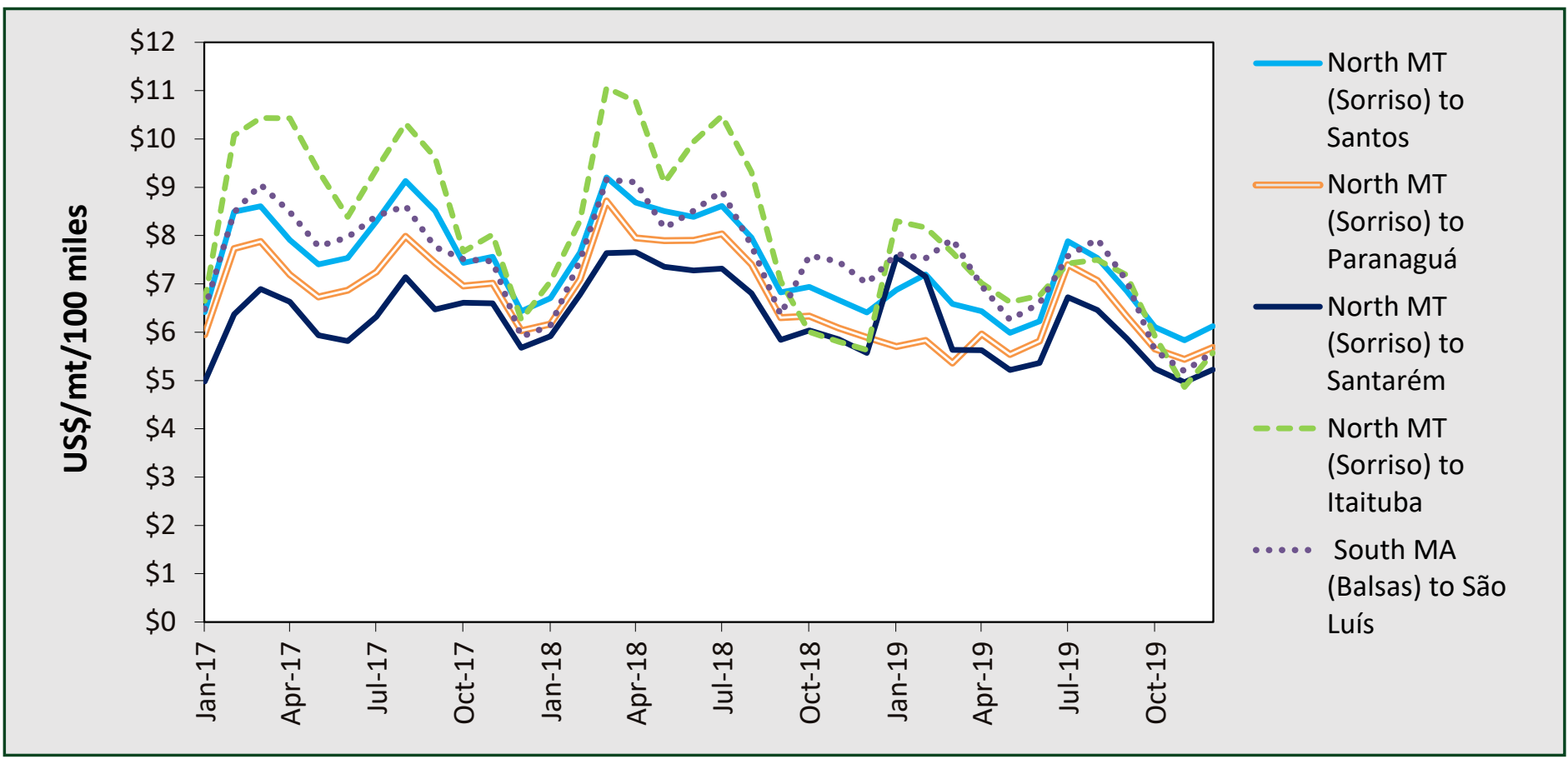

Note: $\mathrm{mt}$ = metric ton. $\mathrm{MT}=$ Mato Grosso and MA = Maranhão.

Source: University of São Paulo, Escola Superior de Agricultura “Luiz de Queiroz," Brazil (ESALQ/USP) and USDA, Agricultural Marketing Service.

Brazilian soybean export truck transportation weighted average prices, 2017-19

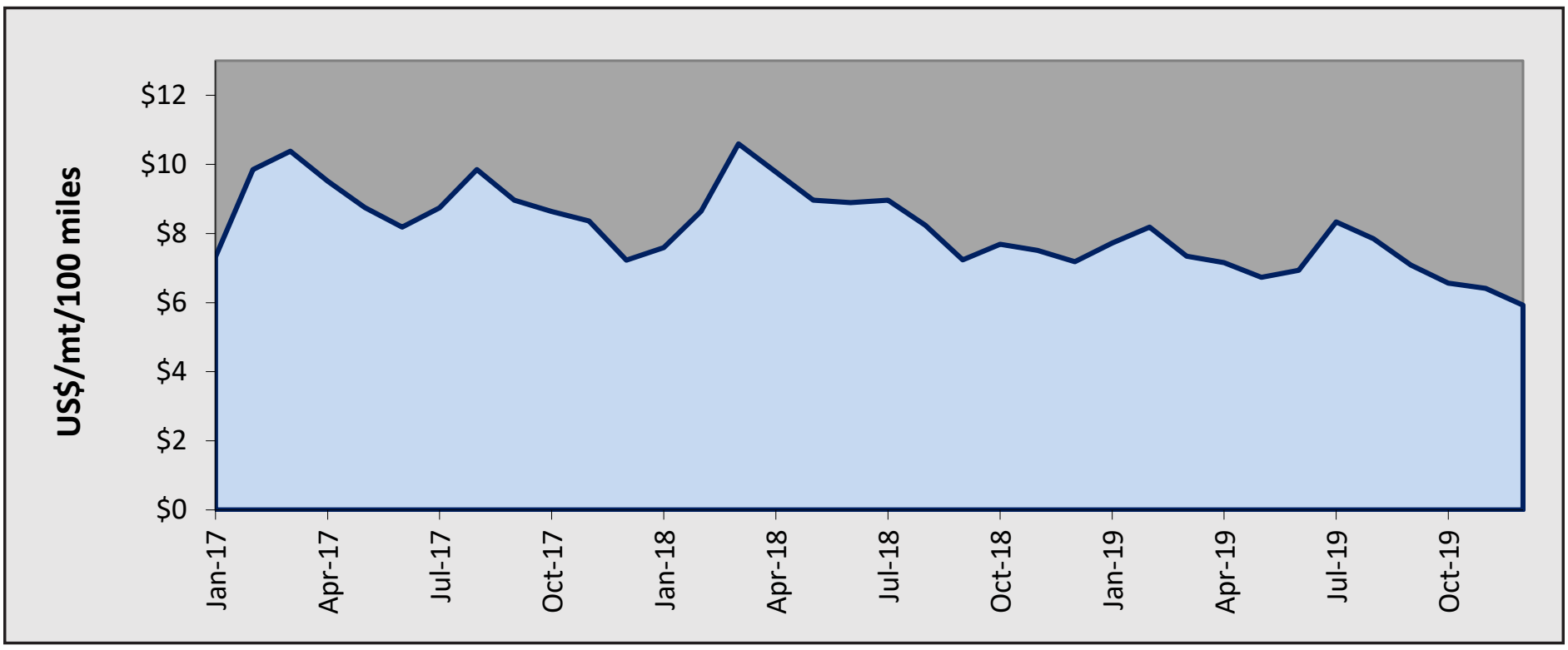

Note: $\mathrm{mt}=$ metric ton.

Source: University of São Paulo, Escola Superior de Agricultura “Luiz de Queiroz," Brazil (ESALQ/USP) and USDA, Agricultural Marketing Service. 


\section{Monthly Brazilian soybean export truck transportation cost index, 2012-19}

\begin{tabular}{|c|c|c|c|c|c|c|c|}
\hline Month & \begin{tabular}{|} 
Freight price \\
(per 100 \\
miles)
\end{tabular} & $\begin{array}{c}\text { Index variation } \\
\text { (\%) (Base: prior } \\
\text { month) }\end{array}$ & $\begin{array}{c}\text { Index value } \\
\text { (Base: Jan. O5 = } \\
\text { 100) }\end{array}$ & Month & $\begin{array}{c}\text { Freight price } \\
\text { (per } 100 \\
\text { miles) }\end{array}$ & $\begin{array}{c}\text { Index variation } \\
\text { (\%) (Base: prior } \\
\text { month) }\end{array}$ & $\begin{array}{c}\text { Index value } \\
\text { (Base: Jan. O5 = } \\
\text { 100) }\end{array}$ \\
\hline Jan-12 & 10.20 & 1.7 & 175.90 & Jan-16 & 6.42 & -5.1 & 110.63 \\
\hline Feb-12 & 10.76 & 5.4 & 185.45 & Feb-16 & 6.73 & 4.8 & 115.98 \\
\hline Mar-12 & 10.55 & -2.0 & 181.82 & Mar-16 & 7.79 & 15.8 & 134.33 \\
\hline Apr-12 & 10.45 & -1.0 & 180.06 & Apr-16 & 8.30 & 6.5 & 143.05 \\
\hline May-12 & 9.64 & -7.7 & 166.20 & May-16 & 7.28 & -12.3 & 125.43 \\
\hline Jun-12 & 9.37 & -2.9 & 161.44 & Jun-16 & 7.16 & -1.5 & 123.51 \\
\hline Jul-12 & 9.76 & 4.2 & 168.16 & Jul-16 & 7.46 & 4.2 & 128.64 \\
\hline Aug-12 & 10.17 & 4.3 & 175.33 & Aug-16 & 7.33 & -1.7 & 126.41 \\
\hline Sep-12 & 10.30 & 1.3 & 177.54 & Sep-16 & 6.35 & -13.3 & 109.53 \\
\hline Oct-12 & 10.13 & -1.6 & 174.66 & Oct-16 & 5.88 & -7.5 & 101.35 \\
\hline Nov-12 & 9.84 & -2.8 & 169.69 & Nov-16 & 5.00 & -14.9 & 86.21 \\
\hline Dec-12 & 9.73 & -1.1 & 167.74 & Dec-16 & 5.47 & 9.4 & 94.32 \\
\hline Jan-13 & 10.11 & 3.9 & 174.31 & Jan-17 & 7.32 & 33.8 & 126.20 \\
\hline Feb-13 & 10.79 & 6.7 & 185.96 & Feb-17 & 9.85 & 34.6 & 169.85 \\
\hline Mar-13 & 11.14 & 3.3 & 192.04 & Mar-17 & 10.38 & 5.3 & 178.90 \\
\hline Apr-13 & 10.95 & -1.7 & 188.71 & Apr-17 & 9.52 & -8.3 & 164.05 \\
\hline May-13 & 10.40 & -5.0 & 179.31 & May-17 & 8.75 & -8.0 & 150.90 \\
\hline Jun-13 & 9.49 & -8.8 & 163.61 & Jun-17 & 8.18 & -6.5 & 141.04 \\
\hline Jul-13 & 9.65 & 1.7 & 166.41 & Jul-17 & 8.74 & 6.8 & 150.66 \\
\hline Aug-13 & 9.80 & 1.5 & 168.95 & Aug-17 & 9.85 & 12.7 & 169.76 \\
\hline Sep-13 & 10.21 & 4.2 & 176.02 & Sep-17 & 8.97 & -9.0 & 154.55 \\
\hline Oct-13 & 10.17 & -0.4 & 175.28 & Oct-17 & 8.64 & -3.6 & 148.93 \\
\hline Nov-13 & 9.29 & -8.6 & 160.18 & Nov-17 & 8.36 & -3.2 & 144.11 \\
\hline Dec-13 & 8.91 & -4.1 & 153.63 & Dec-17 & 7.23 & -13.5 & 124.63 \\
\hline Jan-14 & 8.86 & -0.6 & 152.73 & Jan-18 & 7.59 & 5.0 & 130.90 \\
\hline Feb-14 & 10.34 & 16.7 & 178.24 & Feb-18 & 8.65 & 13.9 & 149.04 \\
\hline Mar-14 & 11.61 & 12.3 & 200.13 & Mar-18 & 10.59 & 22.5 & 182.61 \\
\hline Apr-14 & 11.35 & -2.2 & 195.65 & Apr-18 & 9.78 & -7.7 & 168.59 \\
\hline May-14 & 10.90 & -4.0 & 187.89 & May-18 & 8.96 & -8.4 & 154.45 \\
\hline Jun-14 & 10.34 & -5.1 & 178.24 & Jun-18 & 8.89 & -0.8 & 153.24 \\
\hline Jul-14 & 10.16 & -1.7 & 175.21 & Jul-18 & 8.97 & 0.9 & 154.58 \\
\hline Aug-14 & 10.10 & -0.6 & 174.08 & Aug-18 & 8.24 & -8.1 & 142.00 \\
\hline Sep-14 & 9.66 & -4.3 & 166.54 & Sep-18 & 7.24 & -12.1 & 124.78 \\
\hline Oct-14 & 8.77 & -9.3 & 151.13 & Oct-18 & 7.69 & 6.2 & 132.55 \\
\hline Nov-14 & 8.36 & -4.6 & 144.16 & Nov-18 & 7.51 & -2.3 & 129.44 \\
\hline Dec-14 & 7.96 & -4.9 & 137.15 & Dec-18 & 7.19 & -4.3 & 123.87 \\
\hline Jan-15 & 8.01 & 0.7 & 138.15 & Jan-19 & 7.72 & 7.5 & 133.13 \\
\hline Feb-15 & 8.02 & 0.1 & 138.29 & Feb-19 & 8.19 & 6.0 & 141.15 \\
\hline Mar-15 & 8.32 & 3.7 & 143.44 & Mar-19 & 7.34 & -10.3 & 126.61 \\
\hline Apr-15 & 9.00 & 8.2 & 155.13 & Apr-19 & 7.16 & -2.6 & 123.35 \\
\hline May-15 & 8.39 & -6.8 & 144.58 & May-19 & 6.73 & -5.9 & 116.02 \\
\hline Jun-15 & 8.01 & -4.5 & 138.12 & Jun-19 & 6.94 & 3.1 & 119.56 \\
\hline Jul-15 & 7.56 & -5.7 & 130.25 & Jul-19 & 8.33 & 20.1 & 143.60 \\
\hline Aug-15 & 7.38 & -2.4 & 127.15 & Aug-19 & 7.85 & -5.8 & 135.23 \\
\hline Sep-15 & 6.60 & -10.5 & 113.78 & Sep-19 & 7.09 & -9.7 & 122.17 \\
\hline Oct-15 & 6.70 & 1.5 & 115.43 & Oct-19 & 6.57 & -7.4 & 113.19 \\
\hline Nov-15 & 7.08 & 5.8 & 122.08 & Nov-19 & 6.41 & -2.3 & 110.54 \\
\hline Dec-15 & 6.76 & -4.5 & 116.56 & Dec-19 & 5.93 & -7.5 & 102.21 \\
\hline
\end{tabular}


Quarterly ocean freight rates for shipping soybeans from selected Brazilian ports to Shanghai, China, 2012-19 (US\$/metric ton)*

\begin{tabular}{|c|c|c|c|c|c|}
\hline Port & 1st qtr 2012 & 2nd qtr 2012 & 3rd qtr 2012 & 4th qtr 2012 & 2012 Average \\
\hline Santos & 46.62 & 51.35 & 50.42 & 50.42 & 49.70 \\
\hline Paranaguá & 52.32 & 57.63 & 55.42 & 55.42 & 55.20 \\
\hline Rio Grande & 47.92 & 52.78 & 49.02 & 49.02 & 49.69 \\
\hline Port & 1st qtr 2013 & 2nd qtr 2013 & 3rd qtr 2013 & 4th qtr 2013 & 2013 Average \\
\hline Santos & 52.34 & 34.50 & 34.50 & 42.50 & 40.96 \\
\hline Paranaguá & 56.03 & 36.75 & 36.75 & 46.00 & 43.88 \\
\hline Rio Grande & 51.34 & 35.25 & 35.25 & 44.25 & 41.52 \\
\hline Port & 1st qtr 2014 & 2nd qtr 2014 & 3rd qtr 2014 & 4th qtr 2014 & 2014 Average \\
\hline Santos & 44.83 & 38.07 & 34.00 & 30.50 & 36.85 \\
\hline Paranagua & 47.22 & 41.13 & 36.00 & 32.50 & 39.21 \\
\hline Rio Grande & 44.83 & 38.75 & 32.50 & 30.50 & 36.65 \\
\hline Port & 1st qtr 2015 & 2nd qtr 2015 & 3rd qtr 2015 & 4th qtr 2015 & 2015 Average \\
\hline Santos & 29.50 & 22.50 & 23.25 & 20.00 & 23.81 \\
\hline Paranaguá & 31.50 & 23.50 & 24.18 & 20.50 & 24.92 \\
\hline Rio Grande & 29.50 & 25.00 & 25.75 & 21.00 & 25.31 \\
\hline Santarém & 32.00 & 25.00 & 25.75 & 23.50 & 26.56 \\
\hline São Luís & 32.00 & 25.00 & 25.75 & 23.50 & 26.56 \\
\hline Barcarena & 32.00 & 25.00 & 25.75 & 23.50 & 26.56 \\
\hline Port & 1st qtr 2016 & 2nd qtr 2016 & 3rd qtr 2016 & 4th qtr 2016 & 2016 Average \\
\hline Santos & 17.50 & 16.50 & 12.50 & 20.00 & 16.63 \\
\hline Paranaguá & 18.00 & 18.50 & 14.50 & 21.50 & 18.13 \\
\hline Rio Grande & 18.50 & 17.00 & 13.00 & 20.50 & 17.25 \\
\hline Santarém & 22.00 & 21.00 & 19.40 & 23.75 & 21.54 \\
\hline São Luís & 20.00 & 18.40 & 17.50 & 22.00 & 19.48 \\
\hline Barcarena & 22.50 & 21.50 & 20.00 & 23.75 & 21.94 \\
\hline Port & 1st qtr 2017 & 2nd qtr 2017 & 3rd qtr 2017 & 4th qtr 2017 & 2017 Average \\
\hline Santos & 18.50 & 29.00 & 30.00 & 30.00 & 26.88 \\
\hline Paranaguá & 20.50 & 30.50 & 31.00 & 31.50 & 28.38 \\
\hline Rio Grande & 18.00 & 29.50 & 31.00 & 30.70 & 27.30 \\
\hline Santarém & 24.00 & 33.50 & 31.00 & 34.50 & 30.75 \\
\hline São Luís & 23.50 & 30.25 & 31.00 & 33.50 & 29.56 \\
\hline Barcarena & 24.00 & 33.50 & 31.00 & 34.50 & 30.75 \\
\hline Port & 1st qtr 2018 & 2nd qtr 2018 & 3rd qtr 2018 & 4th qtr 2018 & 2018 Average \\
\hline Santos & 32.50 & 31.00 & 27.75 & 30.00 & 30.31 \\
\hline Paranaguá & 32.00 & 32.00 & 28.75 & 31.00 & 30.94 \\
\hline Rio Grande & 33.00 & 31.50 & 28.25 & 31.00 & 30.94 \\
\hline Santarém & 38.50 & 35.50 & 31.25 & 34.00 & 34.81 \\
\hline São Luís & 37.00 & 34.80 & 30.75 & 33.00 & 33.89 \\
\hline Barcarena & 37.50 & 33.80 & 32.25 & 35.00 & 34.64 \\
\hline Port & 1st qtr 2019 & 2nd qtr 2019 & 3rd qtr 2019 & 4th qtr 2019 & 2019 Average \\
\hline Santos & 32.25 & 30.92 & 33.25 & 38.17 & 33.65 \\
\hline Paranaguá & 33.75 & 31.42 & 34.75 & 39.50 & 34.86 \\
\hline Rio Grande & 31.58 & 30.25 & 30.58 & 39.67 & 33.94 \\
\hline Santarém & 32.25 & 30.58 & 38.25 & 39.17 & 35.06 \\
\hline São Luís & 31.00 & 30.58 & 38.25 & 39.42 & 34.81 \\
\hline Barcarena & 32.25 & 29.92 & 38.25 & 39.42 & 34.96 \\
\hline
\end{tabular}

*The rates correspond to the average actual values negotiated between shippers and carriers and " qtr. = weighted according to the magnitude of the shipped volume.

Note: qtr. = quarter.

Source: University of São Paulo, Escola Superior de Agricultura "Luiz de Queiroz," Brazil (ESALQ/USP) and USDA, Agricultural Marketing Service. 
Quarterly ocean freight rates for shipping soybeans from selected Brazilian ports to Hamburg, Germany, 2012-19 (US\$/metric ton)*

\begin{tabular}{|c|c|c|c|c|c|}
\hline Port & 1st qtr 2012 & 2nd qtr 2012 & 3rd qtr 2012 & 4th qtr 2012 & 2012 Average \\
\hline Santos & 32.00 & 35.00 & 32.00 & 28.00 & 31.75 \\
\hline Paranaguá & 31.58 & 35.00 & 34.30 & 34.30 & 33.80 \\
\hline Rio Grande & 32.08 & 36.50 & 32.00 & 32.00 & 33.15 \\
\hline Port & 1st qtr 2013 & 2nd qtr 2013 & $3 r d$ qtr 2013 & 4th qtr 2013 & 2013 Average \\
\hline Santos & 30.00 & 29.00 & 29.00 & 30.00 & 29.50 \\
\hline Paranaguá & 30.00 & 29.00 & 29.00 & 30.00 & 29.50 \\
\hline Rio Grande & 30.00 & 29.00 & 29.00 & 30.00 & 29.50 \\
\hline Port & 1st qtr 2014 & 2nd qtr 2014 & $3 r d$ qtr 2014 & 4th qtr 2014 & 2014 Average \\
\hline Santos & 31.00 & 30.00 & 26.00 & 24.00 & 27.75 \\
\hline Paranaguá & 31.00 & 30.00 & 28.00 & 26.00 & 28.75 \\
\hline Rio Grande & 31.00 & 30.00 & 24.50 & 22.50 & 27.00 \\
\hline Port & 1st qtr 2015 & 2nd qtr 2015 & 3rd qtr 2015 & 4th qtr 2015 & 2015 Average \\
\hline Santos & 22.00 & 21.00 & 19.00 & 17.00 & 19.75 \\
\hline Paranaguá & 22.00 & 21.00 & 19.00 & 17.00 & 19.75 \\
\hline Rio Grande & 22.00 & 21.00 & 19.00 & 17.00 & 19.75 \\
\hline Santarém & 20.00 & 14.50 & 13.50 & 20.00 & 17.00 \\
\hline São Luís & 20.00 & 18.25 & 16.38 & 20.50 & 18.78 \\
\hline Barcarena & 20.00 & 16.00 & 15.20 & 21.00 & 18.05 \\
\hline Port & 1st qtr 2016 & 2nd qtr 2016 & 3rd qtr 2016 & 4th qtr 2016 & 2016 Average \\
\hline Santos & 16.00 & 17.00 & 16.50 & 23.00 & 18.13 \\
\hline Paranaguá & 16.00 & 17.00 & 16.50 & 24.00 & 18.38 \\
\hline Rio Grande & 16.00 & 17.00 & 16.50 & 23.00 & 18.13 \\
\hline Santarém & 11.03 & 14.13 & 15.00 & 19.80 & 14.99 \\
\hline São Luís & 8.25 & 11.00 & 11.80 & 15.80 & 11.71 \\
\hline Barcarena & 9.60 & 12.45 & 13.20 & 17.35 & 13.15 \\
\hline Port & 1st qtr 2017 & 2nd qtr 2017 & 3rd qtr 2017 & 4th qtr 201 & 2017 Average \\
\hline Santos & 21.00 & 24.00 & 26.00 & 27.00 & 24.50 \\
\hline Paranaguá & 22.00 & 25.00 & 27.00 & 28.00 & 25.50 \\
\hline Rio Grande & 22.00 & 25.00 & 27.00 & 28.00 & 25.50 \\
\hline Santarém & 21.00 & 23.60 & 25.00 & 26.00 & 23.90 \\
\hline São Luís & 17.60 & 20.00 & 21.20 & 22.00 & 20.20 \\
\hline Barcarena & 18.00 & 20.60 & 21.80 & 22.70 & 20.78 \\
\hline Port & 1st qtr 2018 & 2nd qtr 2018 & 3rd qtr 2018 & 4th qtr 2018 & 2018 Average \\
\hline Santos & 27.00 & 25.00 & 24.00 & 25.00 & 25.25 \\
\hline Paranaguá & 28.00 & 26.00 & 25.00 & 26.00 & 26.25 \\
\hline Rio Grande & 28.00 & 26.00 & 25.00 & 26.00 & 26.25 \\
\hline Santarém & 25.00 & 22.90 & 22.50 & 23.00 & 23.35 \\
\hline São Luís & 21.00 & 19.10 & 18.50 & 19.00 & 19.40 \\
\hline Barcarena & 23.00 & 20.90 & 20.20 & 20.00 & 21.03 \\
\hline Port & 1st qtr 2019 & 2nd qtr 2019 & 3rd qtr 2019 & 4th qtr 2019 & 2019 Average \\
\hline Santos & 23.00 & 21.50 & 27.00 & 31.00 & 25.63 \\
\hline Paranaguá & 23.00 & 21.25 & 27.00 & 30.75 & 25.50 \\
\hline Rio Grande & 23.00 & 21.25 & 27.00 & 31.25 & 25.63 \\
\hline Santarém & 21.00 & 20.25 & 25.92 & 26.50 & 23.42 \\
\hline São Luís & 18.00 & 17.10 & 22.77 & 23.50 & 20.34 \\
\hline Barcarena & 19.00 & 17.85 & 23.52 & 24.25 & 21.16 \\
\hline
\end{tabular}

*The rates correspond to the average actual values negotiated between shippers and carriers and " qtr. = weighted according to the magnitude of the shipped volume.

Note: qtr. = quarter.

Source: University of São Paulo, Escola Superior de Agricultura "Luiz de Queiroz," Brazil (ESALQ/USP) and USDA, Agricultural Marketing Service. 


\section{SOYBEAN PRODUCTION}

Soybean production by state, 2018/19-2019/20

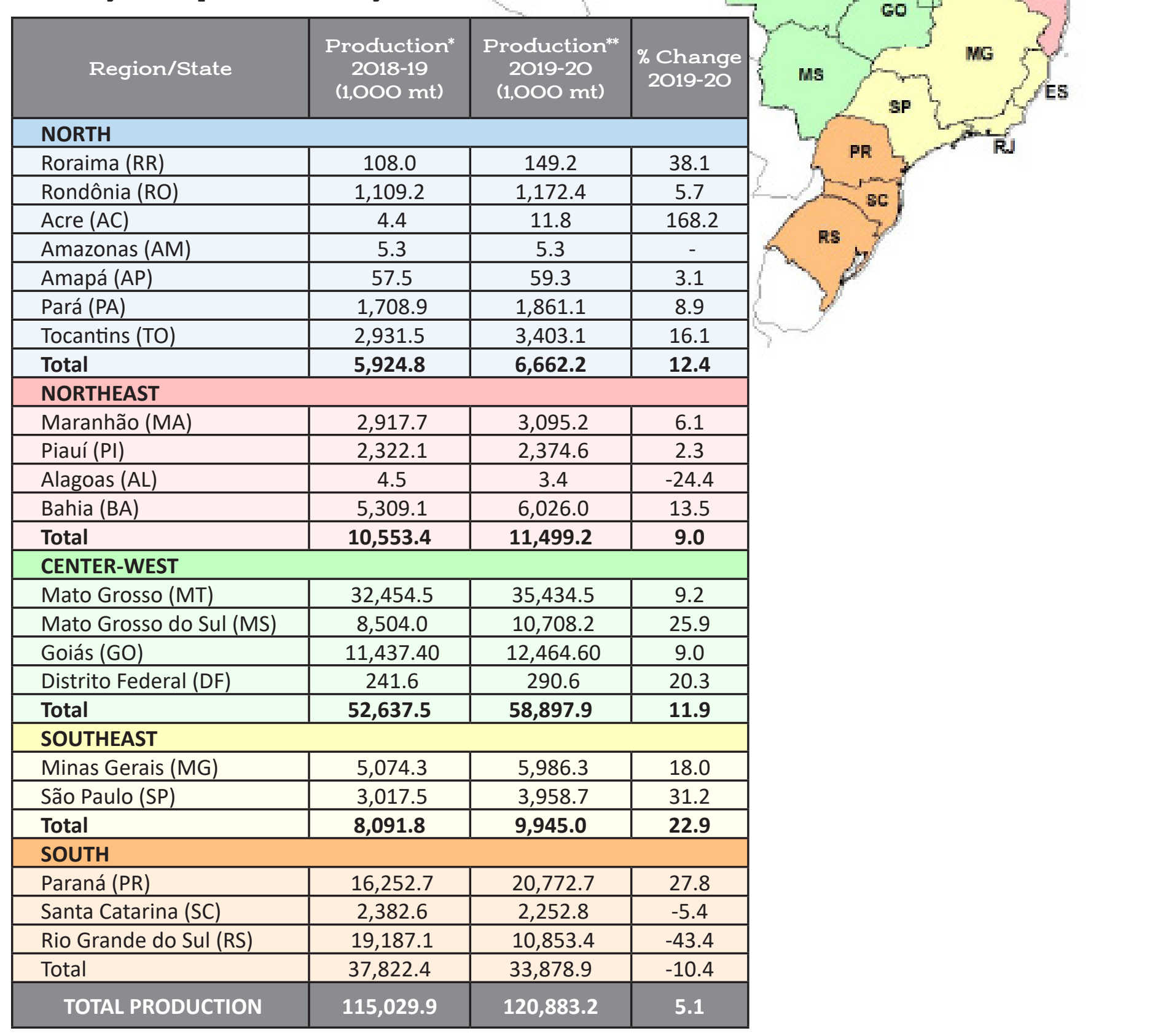

* Data based on calendar year, January-December

**Forecast, July 2020

Source: Companhia Nacional de abastecimento (CONAB). 
Brazil soybean supply and distribution

\begin{tabular}{|c|c|c|c|c|c|c|c|c|c|}
\hline Year* & $\begin{array}{c}\text { Area } \\
\text { harvested }\end{array}$ & $\begin{array}{c}\text { Beginning } \\
\text { stocks }\end{array}$ & Production & Imports & $\begin{array}{c}\text { Total } \\
\text { supply }\end{array}$ & Exports & Crush & $\begin{array}{c}\text { Domestic } \\
\text { consumption }\end{array}$ & $\begin{array}{c}\text { Ending } \\
\text { stocks }\end{array}$ \\
\hline $\begin{array}{c}1,000 \\
\text { hectares }\end{array}$ & \multicolumn{7}{|c|}{1,000 metric tons } \\
\hline $2007 / 08$ & 21,300 & 6,625 & 61,000 & 83 & 67,708 & 24,515 & 31,895 & 34,365 & 8,828 \\
\hline $2008 / 09$ & 21,700 & 8,828 & 57,800 & 124 & 66,752 & 28,041 & 30,779 & 33,129 & 5,582 \\
\hline $2009 / 10$ & 23,500 & 5,582 & 69,000 & 150 & 74,732 & 29,188 & 35,700 & 38,100 & 7,444 \\
\hline $2010 / 11$ & 24,200 & 7,444 & 75,300 & 40 & 82,784 & 33,789 & 37,264 & 39,714 & 9,281 \\
\hline $2011 / 12$ & 25,000 & 9,281 & 66,500 & 298 & 76,079 & 31,905 & 36,230 & 38,730 & 5,444 \\
\hline $2012 / 13$ & 27,700 & 5,444 & 82,000 & 240 & 87,684 & 42,826 & 36,432 & 38,982 & 5,876 \\
\hline $2013 / 14$ & 30,100 & 5,876 & 86,700 & 579 & 93,155 & 45,747 & 38,195 & 40,795 & 6,613 \\
\hline $2014 / 15$ & 32,100 & 6,613 & 97,200 & 329 & 104,142 & 54,635 & 40,339 & 42,989 & 6,518 \\
\hline $2015 / 16$ & 33,300 & 6,518 & 96,500 & 362 & 103,380 & 52,100 & 39,967 & 42,617 & 8,663 \\
\hline $2016 / 17$ & 33,900 & 8,663 & 114,600 & 267 & 123,530 & 68,807 & 42,161 & 44,811 & 9,912 \\
\hline $2017 / 18$ & 35,150 & 9,912 & 122,000 & 185 & 132,097 & 83,729 & 43,389 & 45,716 & 2,652 \\
\hline $2018 / 19$ & 35,900 & 2,652 & 119,000 & 145 & 121,797 & 73,445 & 43,510 & 45,710 & 2,642 \\
\hline $2019 / 20$ & 36,900 & 2,642 & 126,000 & 245 & 128,887 & 79,500 & 44,000 & 46,637 & 2,750 \\
\hline $2020 / 21 * *$ & 38,300 & 2,750 & 131,000 & 150 & 133,900 & 83,000 & 45,000 & 47,650 & 3,250 \\
\hline
\end{tabular}

*Data based on Brazil's local February/January Marketing Year (MY).

Where February 2012 - January 2013 is the 2011/12 MY.

**Forecast, July 10, 2020

Source: USDA/Foreign Agricultural Service/Market and Trade Data/Reports/Oilseeds 


\section{EXPORTS}

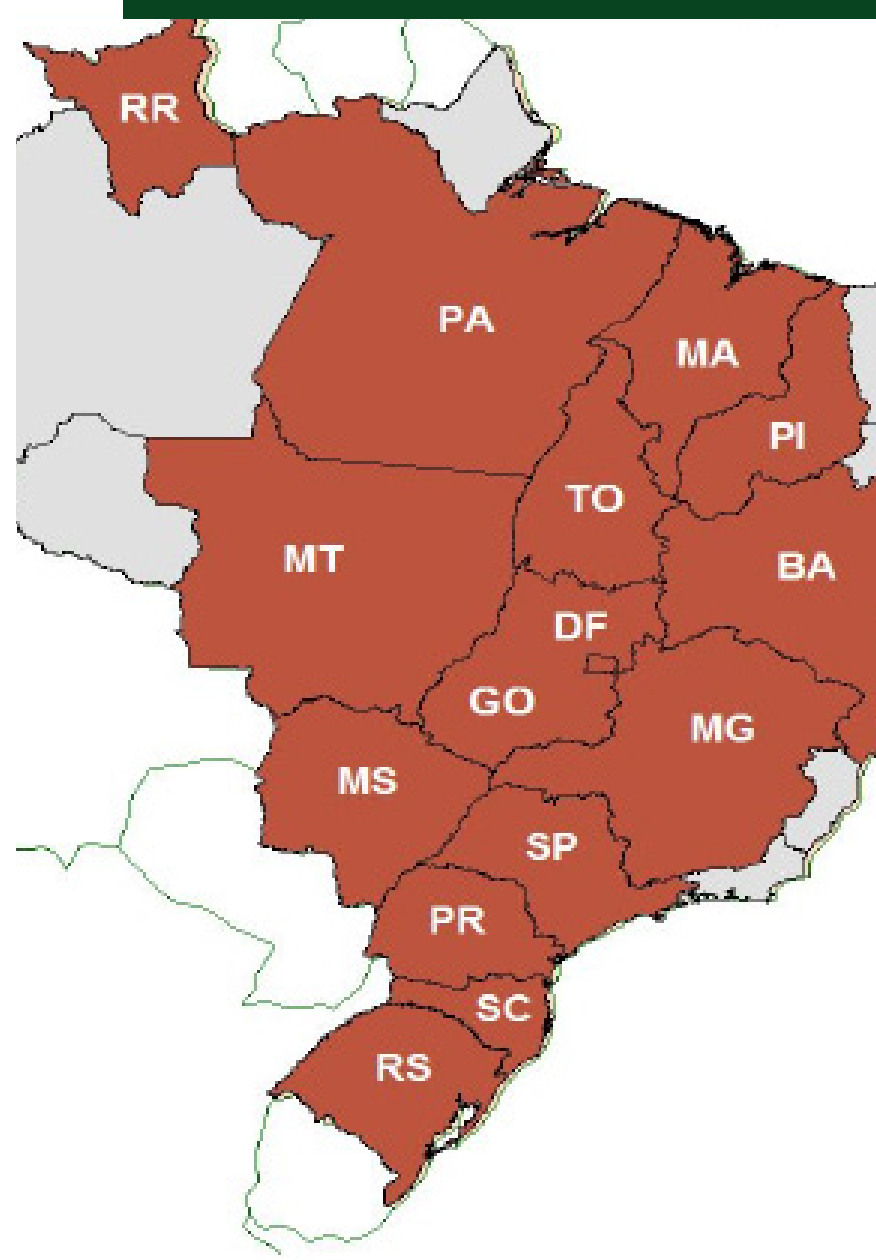


Top five Brazilian soybean exporting states, 2017-19

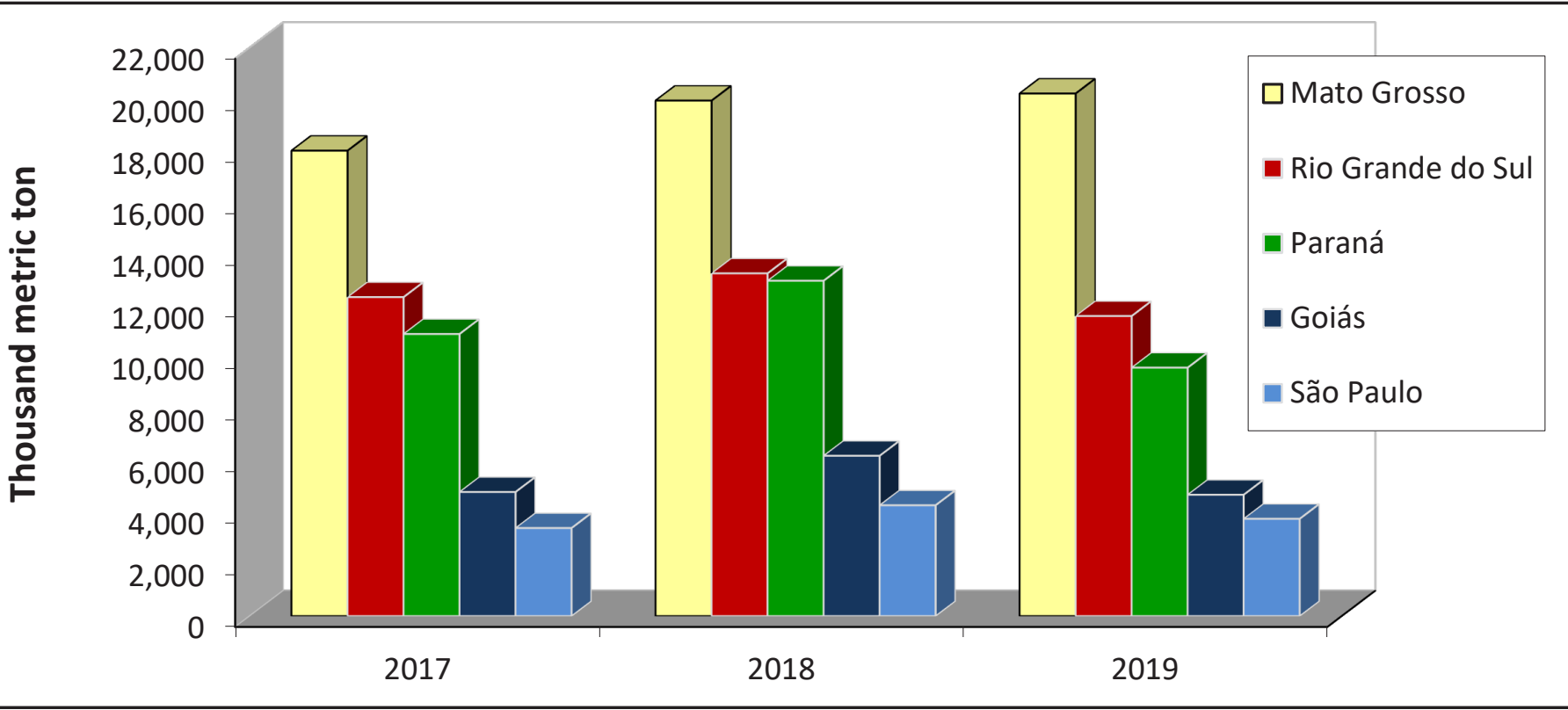

Source: Comex Stat, Ministério da Economia.

Brazil average monthly soybean exports, 2016-19

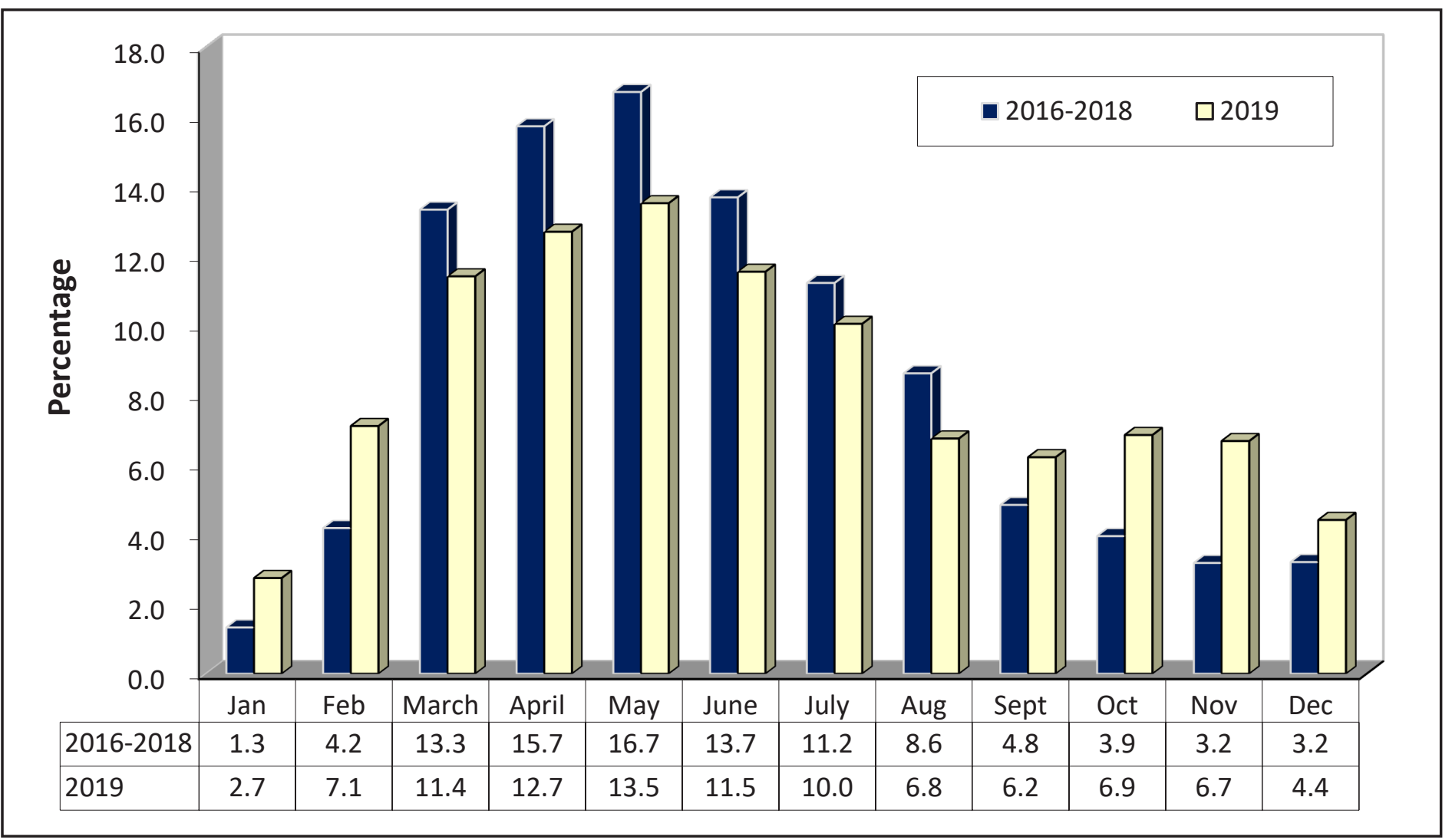

Source: Comex Stat, Ministério da Economia. 


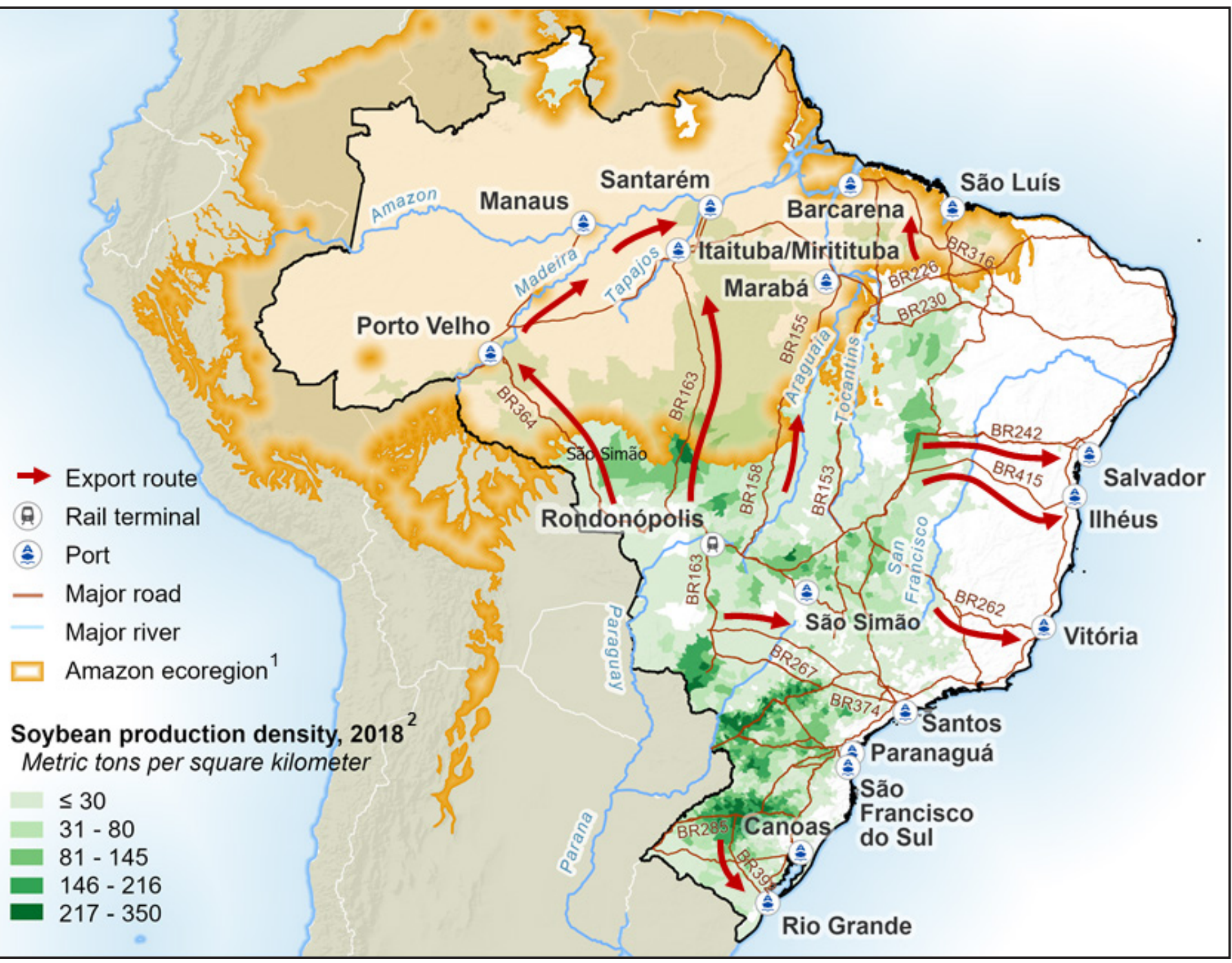

${ }^{1}$ World Wildlife Fund.

${ }^{2}$ Brazilian Institute of Geography and Statistics-Produção Agricola Municipal.

Source: USDA/Agricultural Marketing Service (AMS) and USDA/Foreign Agricultural Service (FAS). 
World export routes for Brazilian soybeans

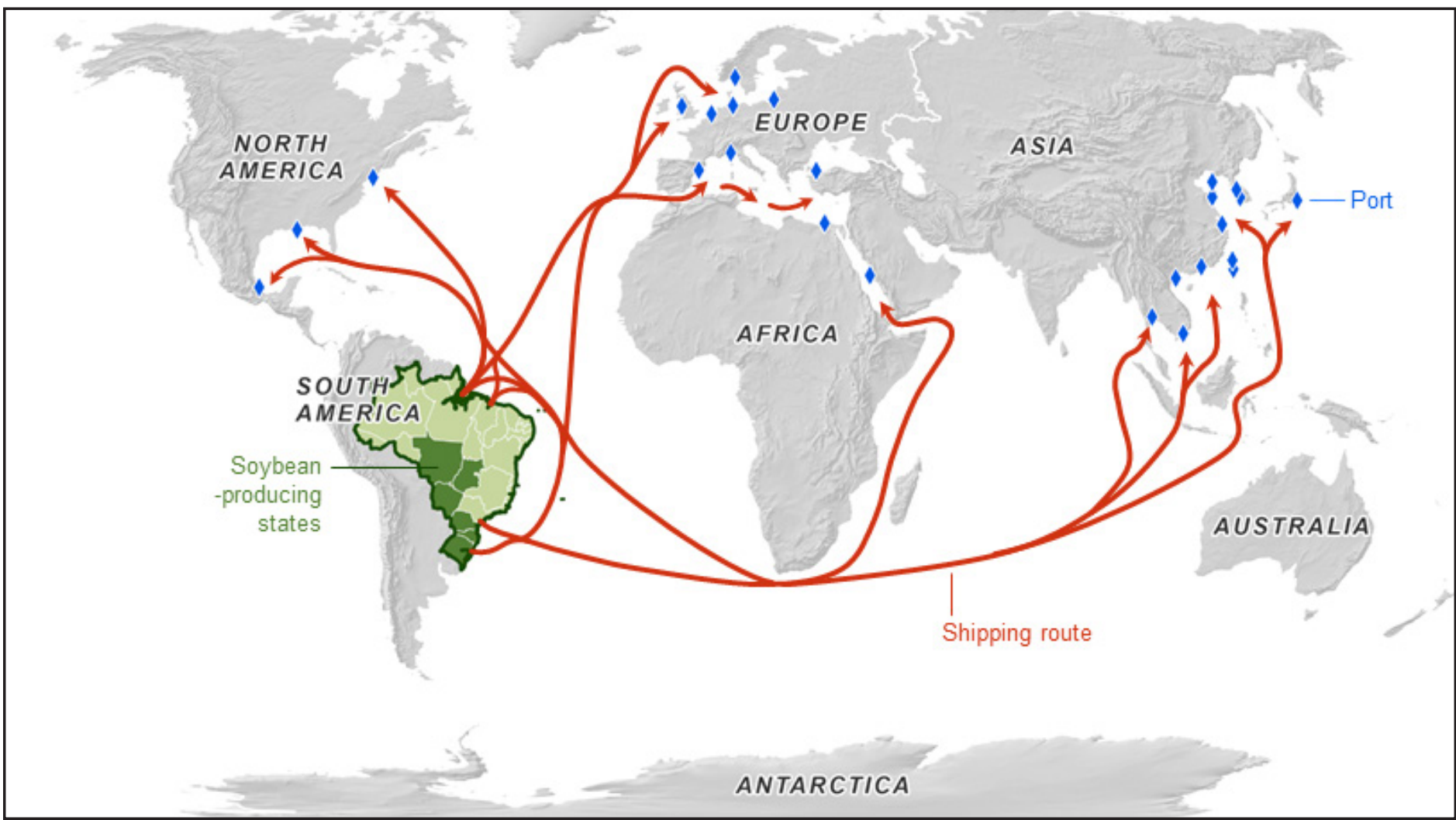

Source:USDA/Agricultural Marketing Service and USDA/Foreign Agricultural Service.

Top five Brazilian soybean-export destinations, 2017-19

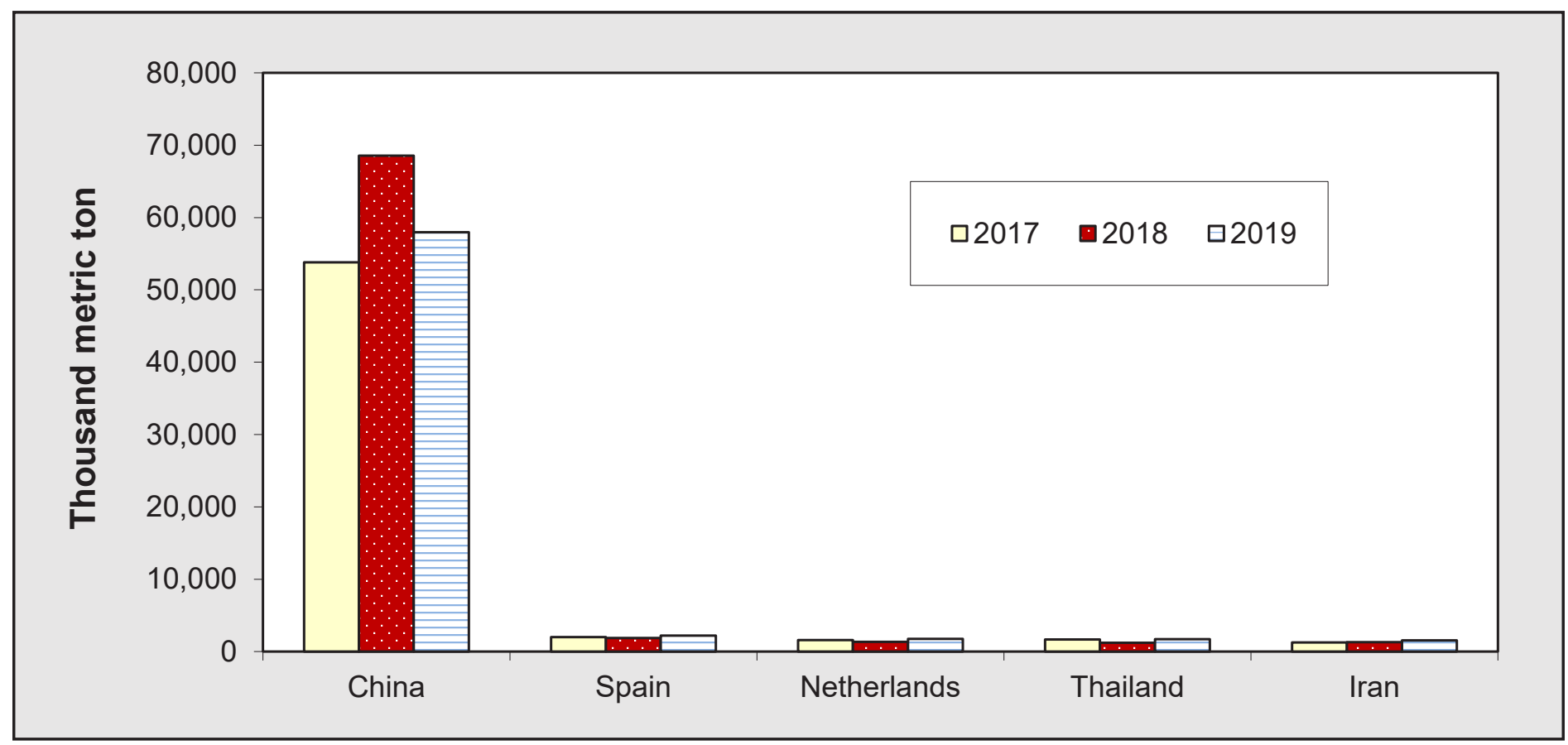

Source: Comex Stat, Ministério da Economia. 
In 2019, Brazil was the leading soybean exporter, followed by the United States, Argentina, Paraguay, and Canada. USDA forecasts that Brazil will sustain its leadership position in 2020.

Top five world soybean-exporting countries, 2018/19-2020/21*

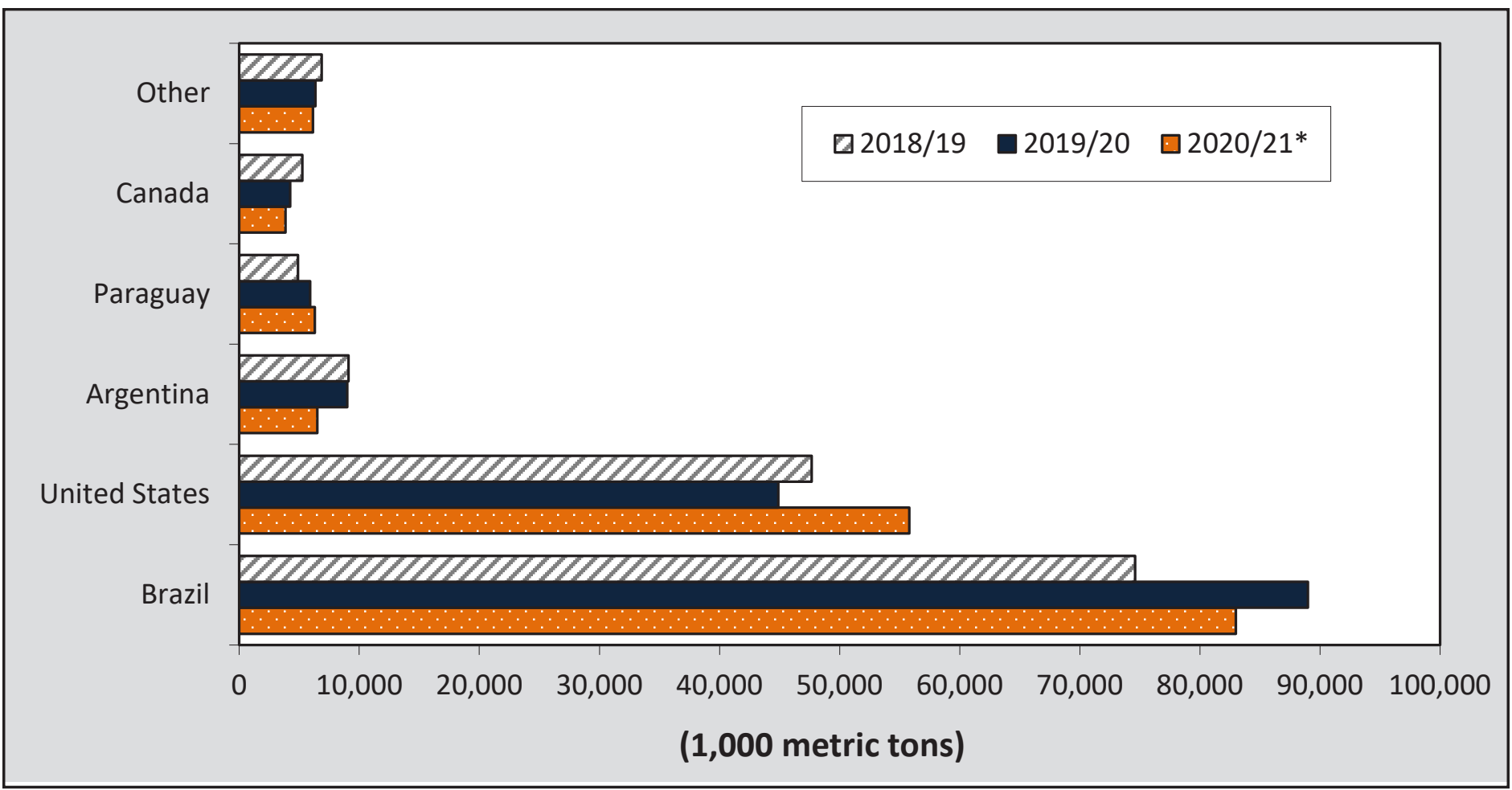

*Forecast July 10, 2020.

Source:USDA/Foreign Agricultural Service/Market and Trade/Reports/PSD Reports/Oilseeds. 


\section{EXPORTS TO CHINA}

Soybean exports to China in 2019 declined nearly 16 percent to $58 \mathrm{mmt}$ (valued at \$20.5 billion) from 68.6 $\mathrm{mmt}$ in 2018, because of an epidemic of African swine fever that reduced the country's hog herd. In 2019, China received 78 percent of Brazil's total soybean exports ( $74 \mathrm{mmt}$ ). Over 90 percent of Brazilian soybean exports to China in 2019 originated from Mato Grosso, Paraná, Rio Grande do Sul, Goiás, Mato Grosso do Sul, Bahia, São Paulo, Minas Gerais, Santa Catarina, and Maranhão.

\section{Brazil average monthly soybean exports to China, 2016-19}

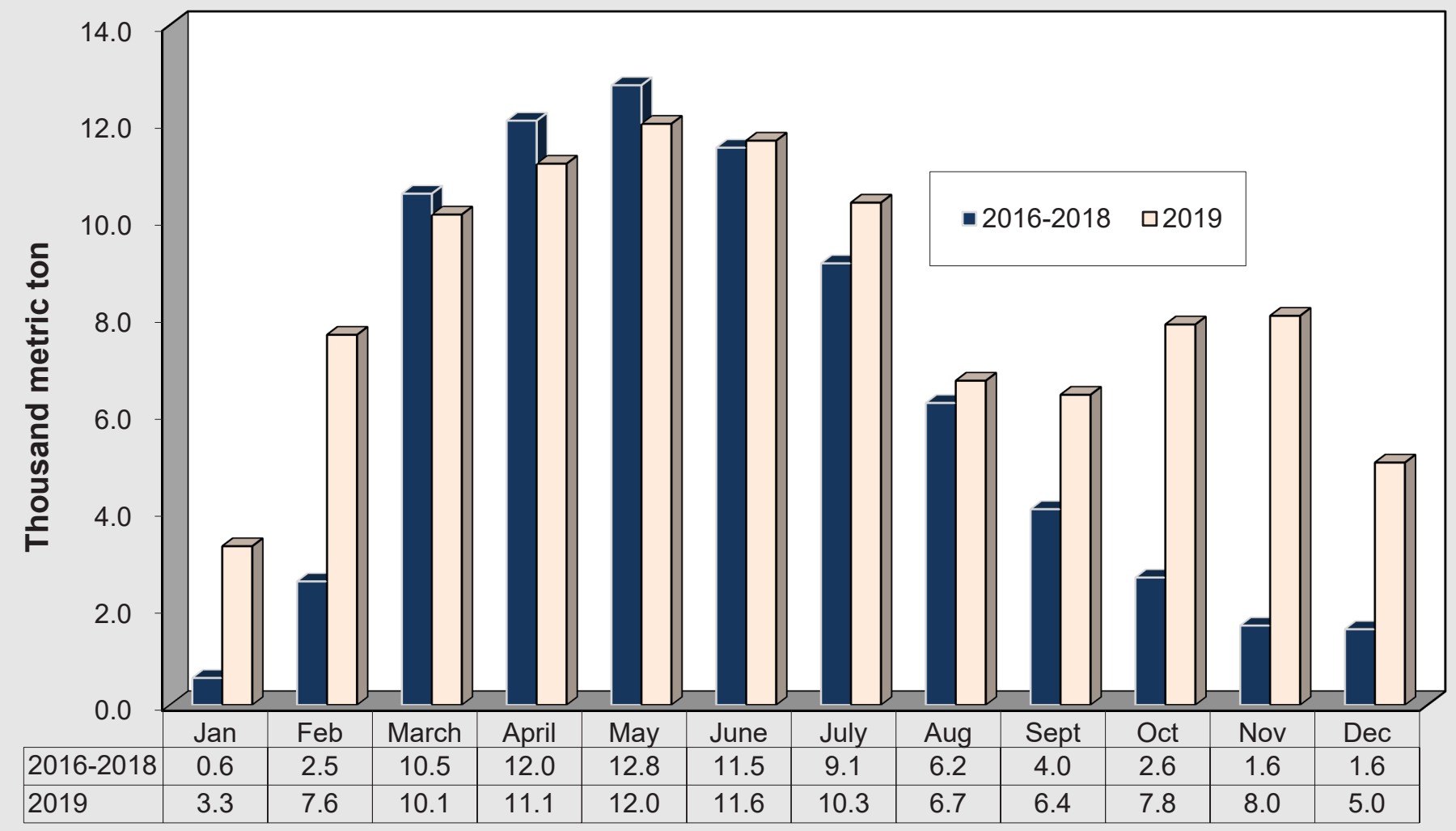

Source: Comex Stat, Ministério da Economia. 
Soybean exports to China in 2019 declined nearly 16 percent to $58 \mathrm{mmt}$ (valued at \$20.5 billion) from 68.6 $\mathrm{mmt}$ in 2018, because of an epidemic of African swine fever that reduced the country's hog herd. Mato Grosso was the top soybean-exporting state to China, followed by Rio Grande do Sul, Paraná, Goiás, and São Paulo.

Top 15 Brazilian soybean exporting states to China, 2017-19

\begin{tabular}{|c|c|c|c|c|}
\hline \multirow{2}{*}{ State } & 2017 & 2018 & 2019 & \multirow{2}{*}{ Ranl } \\
\hline & \multicolumn{3}{|c|}{ metric ton } & \\
\hline Mato Grosso & $11,777,815$ & $12,743,316$ & $12,487,191$ & 1 \\
\hline Rio Grande do Sul & $11,683,177$ & $12,900,417$ & $11,177,365$ & 2 \\
\hline Paraná & $9,677,753$ & $12,252,933$ & $8,553,610$ & 3 \\
\hline Goiás & $4,144,828$ & $5,387,269$ & $3,910,109$ & 4 \\
\hline São Paulo & $2,926,939$ & $3,793,637$ & $3,282,430$ & 5 \\
\hline Bahia & $2,472,074$ & $3,817,777$ & $2,698,728$ & 6 \\
\hline Minas Gerais & $2,337,977$ & 3,271,399 & $2,568,900$ & 7 \\
\hline Mato Grosso do Sul & $2,971,048$ & $4,315,265$ & $2,490,965$ & 8 \\
\hline Maranhão & $1,307,617$ & $2,067,352$ & $1,746,621$ & 9 \\
\hline Tocantins & $1,450,727$ & $2,040,447$ & $1,691,598$ & 10 \\
\hline Santa Catarina & $1,472,302$ & $2,226,527$ & $1,636,180$ & 11 \\
\hline Piauí & 580,826 & $1,411,692$ & 995,313 & 13 \\
\hline Pará & 567,784 & 806,366 & 777,540 & 12 \\
\hline Distrito Federal & 209,552 & 296,401 & 130,524 & 14 \\
\hline Rondônia & 140,063 & 141,332 & 121,827 & 15 \\
\hline Others & 76,502 & $1,084,496$ & $3,694,577$ & \\
\hline Brazil exports to China & $53,796,980$ & $68,556,624$ & $57,963,479$ & 78.3 \\
\hline Brazil total exports & $68,147,705$ & $83,246,813$ & $74,063,633$ & \\
\hline
\end{tabular}

Source: Comex Stat, Ministério da Economia. 
Top 15 Mato Grosso soybean exports destinations, 2017-19

\begin{tabular}{|c|c|c|c|c|c|}
\hline \multirow{2}{*}{ State } & 2017 & 2018 & 2019 & \multirow{2}{*}{$\%$ share } & \multirow{2}{*}{ Ranl } \\
\hline & \multicolumn{3}{|c|}{ metric ton } & & \\
\hline China & $11,777,815$ & $12,743,316$ & $12,487,191$ & 61.7 & 1 \\
\hline Spain & $1,177,825$ & $1,208,445$ & $1,146,825$ & 5.7 & 2 \\
\hline Netherlands & 838,675 & 840,285 & $1,010,715$ & 5.0 & 3 \\
\hline Turkey & 189,895 & 884,021 & 875,285 & 4.3 & 4 \\
\hline Iran & 490,405 & 503,935 & 747,222 & 3.7 & 5 \\
\hline Russia & 610,694 & 161,164 & 595,929 & 2.9 & 6 \\
\hline Thailand & 803,644 & 495,137 & 551,291 & 2.7 & 7 \\
\hline Mexico & 132,914 & 272,165 & 497,229 & 2.5 & 8 \\
\hline Norway & 240,625 & 270,688 & 346,394 & 1.7 & 9 \\
\hline Taiwan & 237,731 & 184,008 & 255,734 & 1.3 & 10 \\
\hline Pakistan & 136,075 & 187,837 & 224,425 & 1.1 & 11 \\
\hline Saudi Arabia & 113,046 & 144,832 & 209,890 & 1.0 & 12 \\
\hline Italy & 130,625 & 150,244 & 185,594 & 0.9 & 13 \\
\hline Tunisia & 9,138 & 139,760 & 173,451 & 0.9 & 14 \\
\hline Portugal & 101,394 & 227,797 & 160,391 & 0.8 & 15 \\
\hline Others & $1,026,956$ & $1,540,408$ & 760,814 & 3.8 & \\
\hline \multirow[t]{2}{*}{ Mato Grosso total } & $18,017,456$ & $19,954,041$ & $20,228,381$ & 100.0 & \\
\hline & & 2017 & 2018 & 2019 & \\
\hline \multicolumn{2}{|c|}{ MT \% share of Brazil exports to China } & 21.9 & 18.6 & 21.5 & \\
\hline \multicolumn{2}{|l|}{ Brazil exports to China } & $53,796,980$ & $68,556,624$ & $57,963,479$ & \\
\hline \multicolumn{2}{|l|}{ Brazil total exports } & $68,147,705$ & $83,246,813$ & $74,063,633$ & \\
\hline \multicolumn{2}{|c|}{ China \% share of Brazil total exports } & 78.9 & 75.2 & 78.3 & \\
\hline
\end{tabular}

Source: Comex Stat, Ministério da Economia. 
Soybean trade to China is dominated by the southern ports of Santos, Rio Grande, Paranaguá, and São Francisco do Sul, which account for about 72 percent of Brazil's soybean exports to China. Meanwhile, the northeastern ports of São Luís, Vitória, Salvador, and Barcarena accounted for nearly 26 percent of exports to China. The Amazon River ports of Manaus and Santarém exported nearly 2 percent to China.

Total Brazilian soybean exports by port to China, 2017-19

\begin{tabular}{|c|c|c|c|}
\hline \multirow{2}{*}{ Ports } & 2017 & 2018 & 2019 \\
\hline & \multicolumn{3}{|c|}{ metric ton } \\
\hline Santos & $14,183,986$ & $17,601,053$ & $14,433,778$ \\
\hline Rio Grande & $11,901,538$ & $13,391,122$ & $12,764,079$ \\
\hline Paranaguá & $10,026,648$ & $14,056,377$ & $10,542,591$ \\
\hline São Luís & $4,246,740$ & $6,982,873$ & $6,271,719$ \\
\hline São Francisco do Sul & $3,984,947$ & $5,252,417$ & $3,852,101$ \\
\hline Subtotal & $44,343,859$ & $57,283,842$ & $47,864,269$ \\
\hline Others & $9,453,121$ & $11,272,781$ & $10,099,211$ \\
\hline Total exports to China & $53,796,980$ & $68,556,624$ & $57,963,479$ \\
\hline Brazil total exports & $68,147,705$ & $83,246,813$ & $74,063,633$ \\
\hline \multirow{2}{*}{ Ports } & 2017 & 2018 & 2019 \\
\hline & \multicolumn{3}{|c|}{$\%$ share of exports to China } \\
\hline Santos & 26.4 & 25.7 & 24.9 \\
\hline Rio Grande & 22.1 & 19.5 & 22.0 \\
\hline Paranaguá & 18.6 & 20.5 & 18.2 \\
\hline São Luís & 7.9 & 10.2 & 10.8 \\
\hline São Francisco do Sul & 7.4 & 7.7 & 6.6 \\
\hline Subtotal & 82.4 & 83.6 & 82.6 \\
\hline Others & 17.6 & 16.4 & 17.4 \\
\hline Total exports to China & 100 & 100 & 100 \\
\hline \multirow{2}{*}{ Ports } & 2017 & 2018 & 2019 \\
\hline & \multicolumn{3}{|c|}{$\%$ share of Brazil total exports } \\
\hline Santos & 20.8 & 21.1 & 19.5 \\
\hline Rio Grande & 17.5 & 16.1 & 17.2 \\
\hline Paranaguá & 14.7 & 16.9 & 14.2 \\
\hline São Luís & 6.2 & 8.4 & 8.5 \\
\hline São Francisco do Sul & 5.8 & 6.3 & 5.2 \\
\hline Subtotal & 65.1 & 68.8 & 64.6 \\
\hline Others & 13.9 & 13.5 & 13.6 \\
\hline Total exports to China & 78.9 & 82.4 & 78.3 \\
\hline
\end{tabular}

Source: Comex Stat, Ministério da Economia. 
Brazil soybean exports to China by port, 2018-19

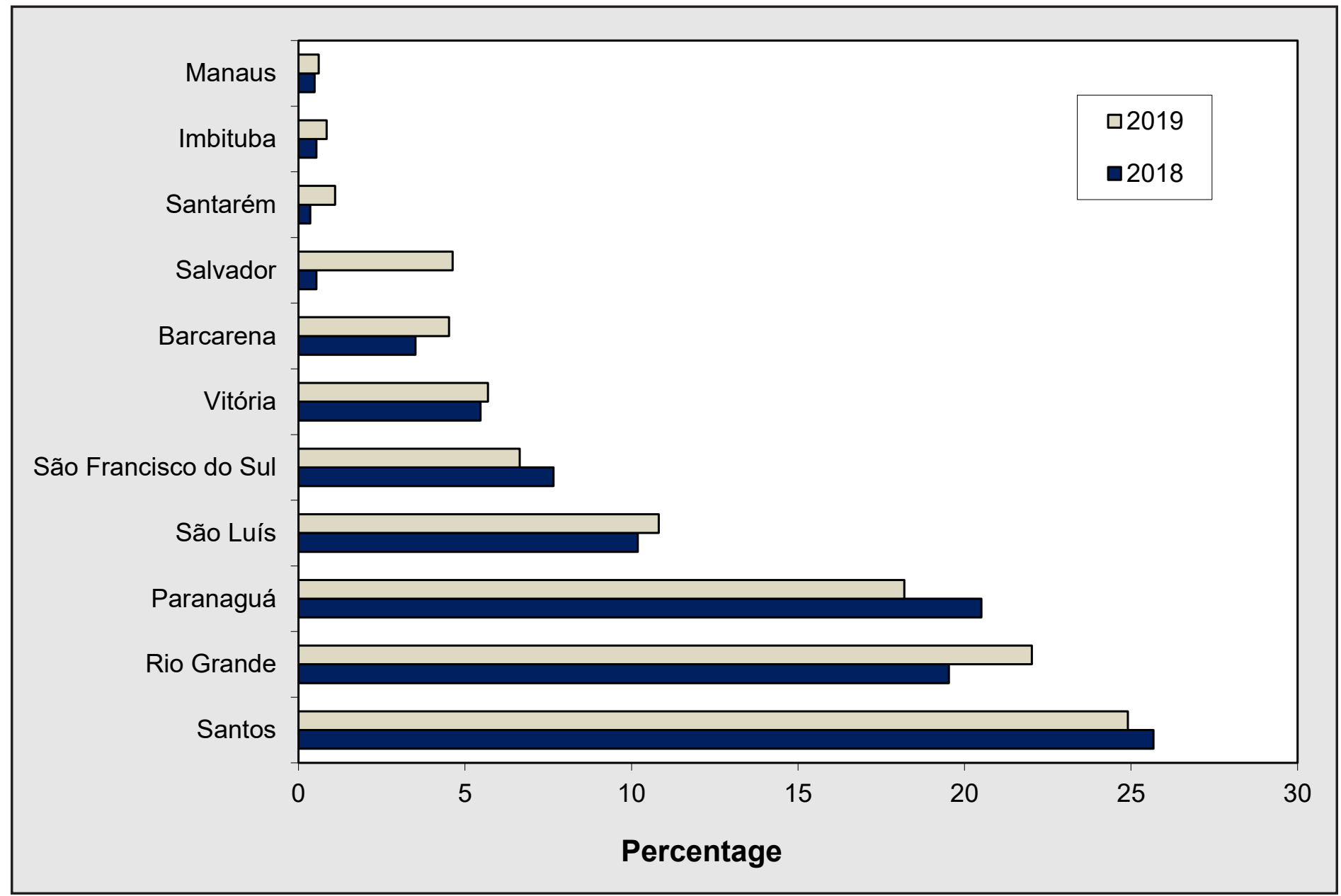

Source: Comex Stat, Ministério da Economia. 
Distance from selected Brazilian ports to Shanghai, China and Hamburg, Germany

\begin{tabular}{|c|c|c|c|c|c|}
\hline Brazilian port & Region & Route through & Destination & Nautical miles & Days at sea* \\
\hline Santos, SP & South & Good Hope & Shanghai, China & 11,056 & 32.22 \\
\hline Santos, SP & South & & Hamburg, Germany & 5,683 & 16.22 \\
\hline Rio Grande, RS & South & Good Hope & Shanghai, China & 11,129 & 33.03 \\
\hline Rio Grande, RS & South & Panama Canal & Shanghai, China & 13,564 & 40.09 \\
\hline Rio Grande, RS & South & Cape Horn & Shanghai, China & 11,397 & 33.22 \\
\hline Rio Grande, RS & South & & Hamburg, Germany & 6,204 & 18.11 \\
\hline Paranaguá, PR & South & Good Hope & Shanghai, China & 11,111 & 33.02 \\
\hline Paranaguá, PR & South & Panama Canal & Shanghai, China & 13,165 & 39.04 \\
\hline Paranaguá, PR & South & & Hamburg, Germany & 5,805 & 17.07 \\
\hline São Francisco do Sul, SC & South & Good Hope & Shanghai, China & 11,111 & 33.4 \\
\hline São Francisco do Sul, SC & South & & Hamburg, Germany & 5,805 & 17.1 \\
\hline Vitória, ES & Southeast & Good Hope & Shanghai, China & 10,857 & 32.08 \\
\hline Vitória, ES & Southeast & Panama Canal & Shanghai, China & 12,587 & 37.11 \\
\hline Vitória, ES & Southeast & & Hamburg, Germany & 5,227 & 15.13 \\
\hline Salvador, BA & Northeast & Good Hope & Shanghai, China & 10,997 & 32.18 \\
\hline Salvador, BA & Northeast & Panama Canal & Shanghai, China & 12,170 & 36.05 \\
\hline Salvador, BA & Northeast & & Hamburg, Germany & 4,811 & 14.08 \\
\hline Aratu, BA & Northeast & Good Hope & Shanghai, China & 10,997 & 32.18 \\
\hline Aratu, BA & Northeast & Panama Canal & Shanghai, China & 12,170 & 36.05 \\
\hline Aratu, BA & Northeast & & Hamburg, Germany & 4,811 & 14.08 \\
\hline Itaquí/Sâo Luís - Ponta de Madeira (MA) & Northeast & Good Hope & Shanghai, China & 11,708 & 34.2 \\
\hline Itaquí/Sâo Luís - Ponta de Madeira (MA) & Northeast & Panama Canal & Shanghai, China & 11,087 & 33 \\
\hline Itaquí/Sâo Luís - Ponta de Madeira (MA) & Northeast & & Hamburg, Germany & 4,361 & 13 \\
\hline $\begin{array}{l}\text { Santarém, (PA)** } \\
\text { Reference point for Itaituba/Miritituba }\end{array}$ & North & Good Hope & Shanghai, China & 12,305 & 37.8 \\
\hline $\begin{array}{l}\text { Santarém, }(\mathrm{PA})^{* *} \\
\text { Reference point for Itaituba/Miritituba }\end{array}$ & North & Panama Canal & Shanghai, China & 11,200 & 33.1 \\
\hline $\begin{array}{l}\text { Santarém, }(\mathrm{PA})^{* *} \\
\text { Reference point for Itaituba/Miritituba }\end{array}$ & North & & Hamburg, Germany & 4,750 & 14.18 \\
\hline Manaus, (AM) & North & Good Hope & Shanghai, China & 12,880 & 38.04 \\
\hline Manaus, (AM) & North & Panama Canal & Shanghai, China & 10,926 & 32.12 \\
\hline Manaus, (AM) & North & & Hamburg, Germany & 5,283 & 15.17 \\
\hline Barcarena, $(\mathrm{PA})^{* *}$ & North & Good Hope & Shanghai, China & 11,905 & 35.6 \\
\hline Barcarena, $(\mathrm{PA}) * *$ & North & Panama Canal & Shanghai, Chin & 10,950 & 32.6 \\
\hline Barcarena, $(\mathrm{PA})^{* *}$ & North & & Hamburg, Germany & 4,510 & 13.6 \\
\hline
\end{tabular}

*Vessel speed: 14 knots.

**Barcarena is located 49 nautical miles from Belém; Itaituba is located 140 nautical miles from Santarém.

Source: http://sea-distances.com/ and 1Ports.com. 
In 2019, China was the major destination for Brazilian soybeans through the port of Santos, Brazil's largest soybean-exporting port. The next-largest destinations (in descending order) were Thailand, Pakistan, Iran, and Taiwan. The peak of soybean shipments to China from Santos usually occurs from March to May. About half of the soybean exports, through Santos, originated from Mato Grosso, followed (in descending order) by São Paulo, Goiás, Minas Gerais, Mato Grosso do Sul, and Paraná.

\section{Port of Santos soybean exports by country, 2018-19}

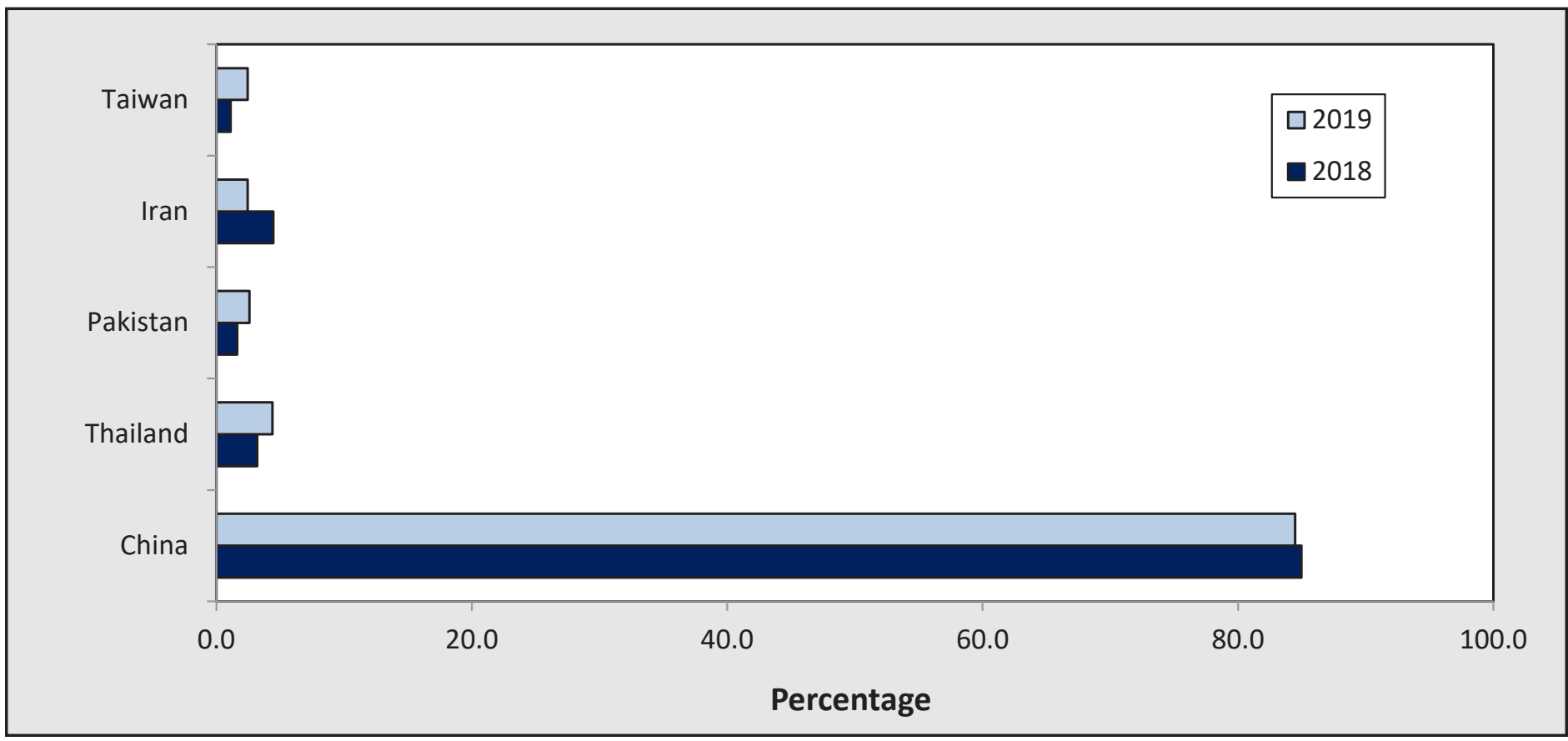

Source: Comex Stat, Ministério da Economia.

Port of Santos soybean average monthly exports to China, 2016-19

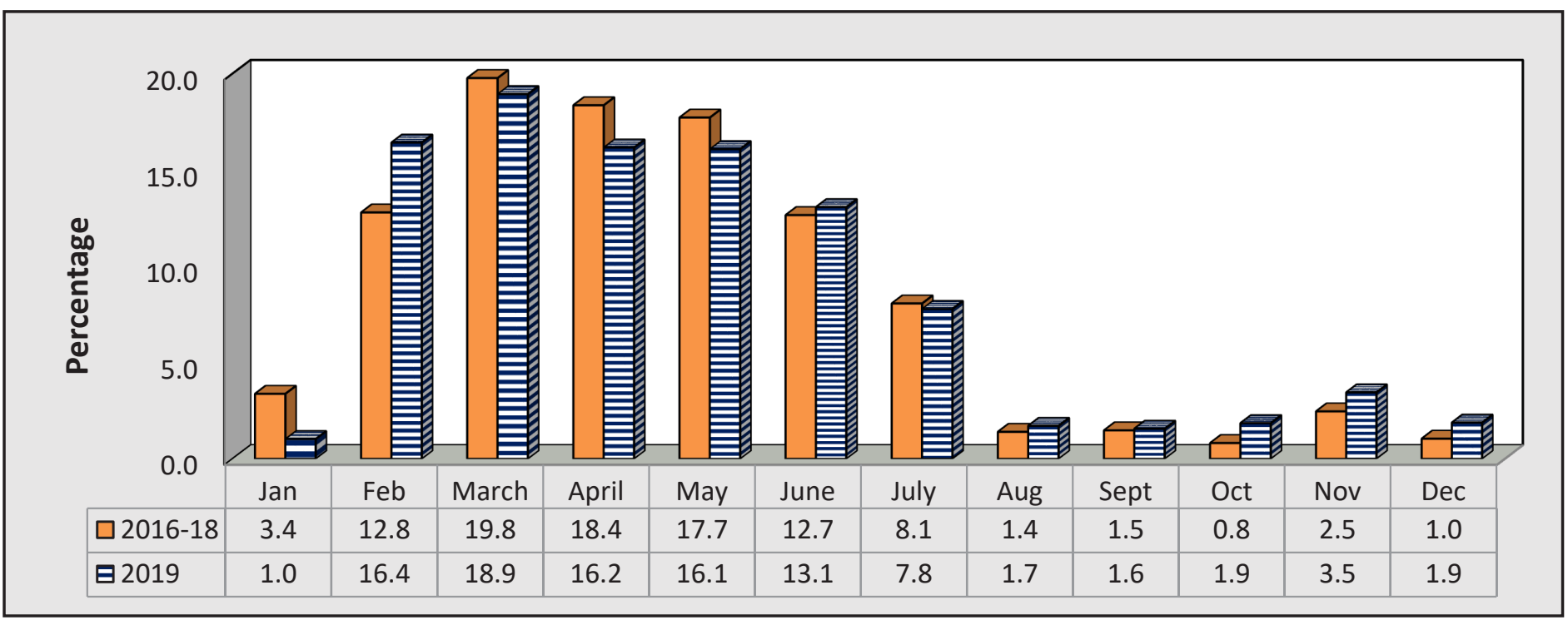

Source: Comex Stat, Ministério da Economia. 
China was the major destination for Brazilian soybeans via the port of Rio Grande, accounting for nearly 97 percent, followed by Iran, Russia, Taiwan, Indonesia, and Turks and Caicos. Typically, soybean shipments to China through the port of Rio Grande peak from April to August. However, in 2019, significant shipments occurred throughout the end of the year. About 86 percent of the soybean exports through the Port of Rio Grande originated from Rio Grande do Sul. The next-highest levels of exports originated (in descending order) from the following ports: Paraná, Minas Gerais, Santa Catarina, São Paulo, and Mato Grosso.

\section{Port of Rio Grande soybean average monthly exports to China, 2016-19}

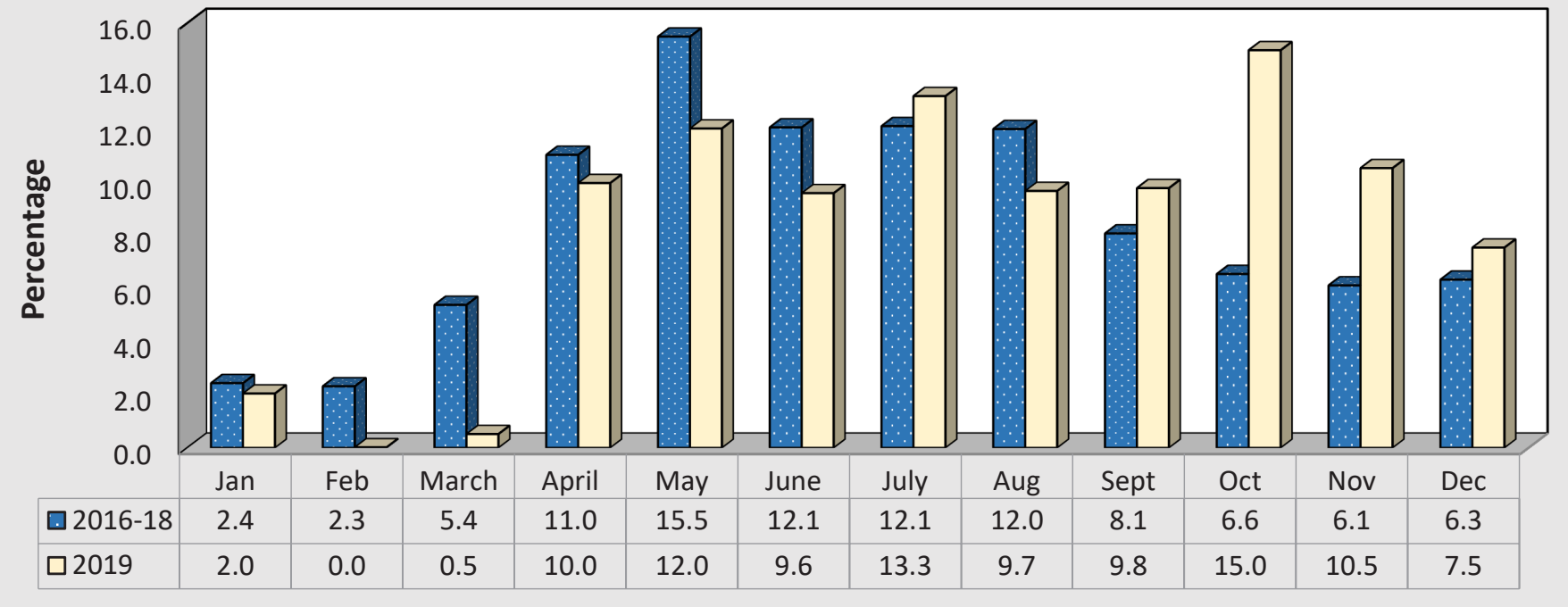

Source: Comex Stat, Ministério da Economia.

China was the top Brazilian soybean export destination through the Port of Paranaguá. The next-largest export destinations (in descending order) were the Netherlands, Pakistan, Bangladesh, and Vietnam. Typically, soybean shipments to China from Paranaguá peak from March to June. Sixty percent of Paranaguá exports originated from Paraná. The next-highest levels of Paranaguá exports (in descending order) originated from Mato Grosso do Sul, Mato Grosso, Santa Catarina, and São Paulo.

Port of Paranaguá soybean average monthly exports to China, 2016-19

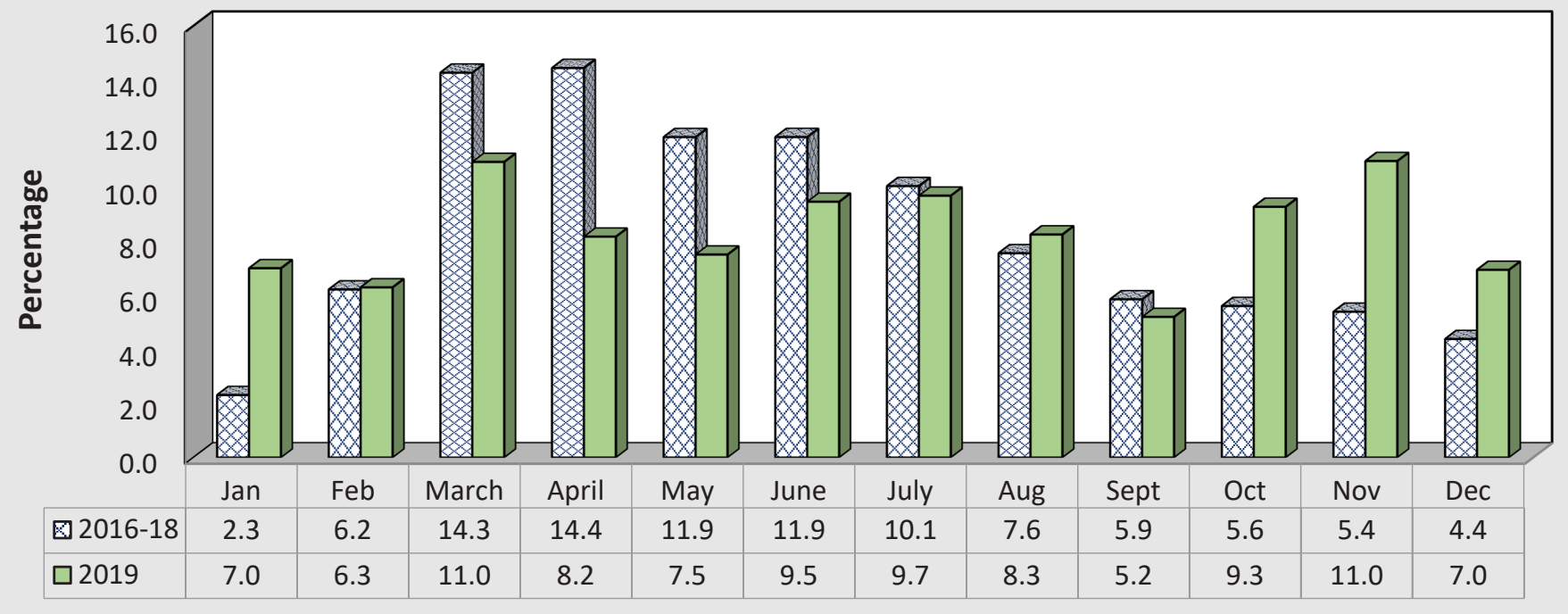

Source: Comex Stat, Ministério da Economia. 
China was top Brazilian soybean export destination through the Port of São Luís. The next-largest export destinations (in descending order) were Spain, Thailand, Japan, Vietnam, and Saudi Arabia. Typically, soybean shipments to China from the Port of São Luís peak from March to June, but in 2019, the peak occurred in January. São Luís is Brazil's top soybean-exporting port in the northeast, accounting for nearly 11 percent of Brazilian total soybean exports and exports to China. The next-highest levels of exports (in descending order) in the northeast were from the following ports: Vitória, Barcarena, Salvador, Santarém, and Manaus. These 4 ports accounted for nearly 26 percent of the total exports to China. About 89 percent of exports of the port of São Luís originated from Maranhão, Tocantins, Mato Grosso, and Piauí.

Port of São Luís average monthly soybean exports to China, 2016-19

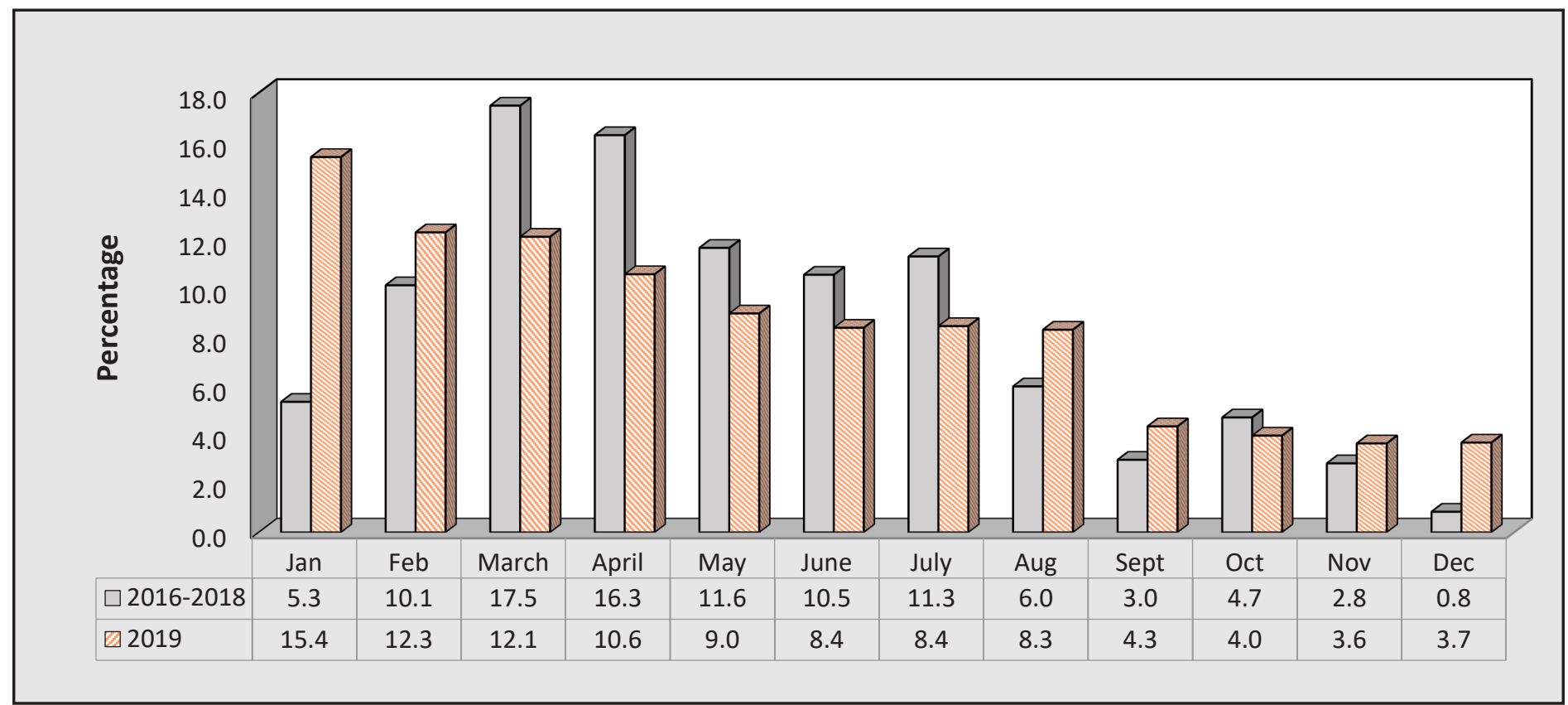

Source: Comex Stat, Ministério da Economia. 


\section{TRANSPORTATION MODES}

\section{Brazilian ports}

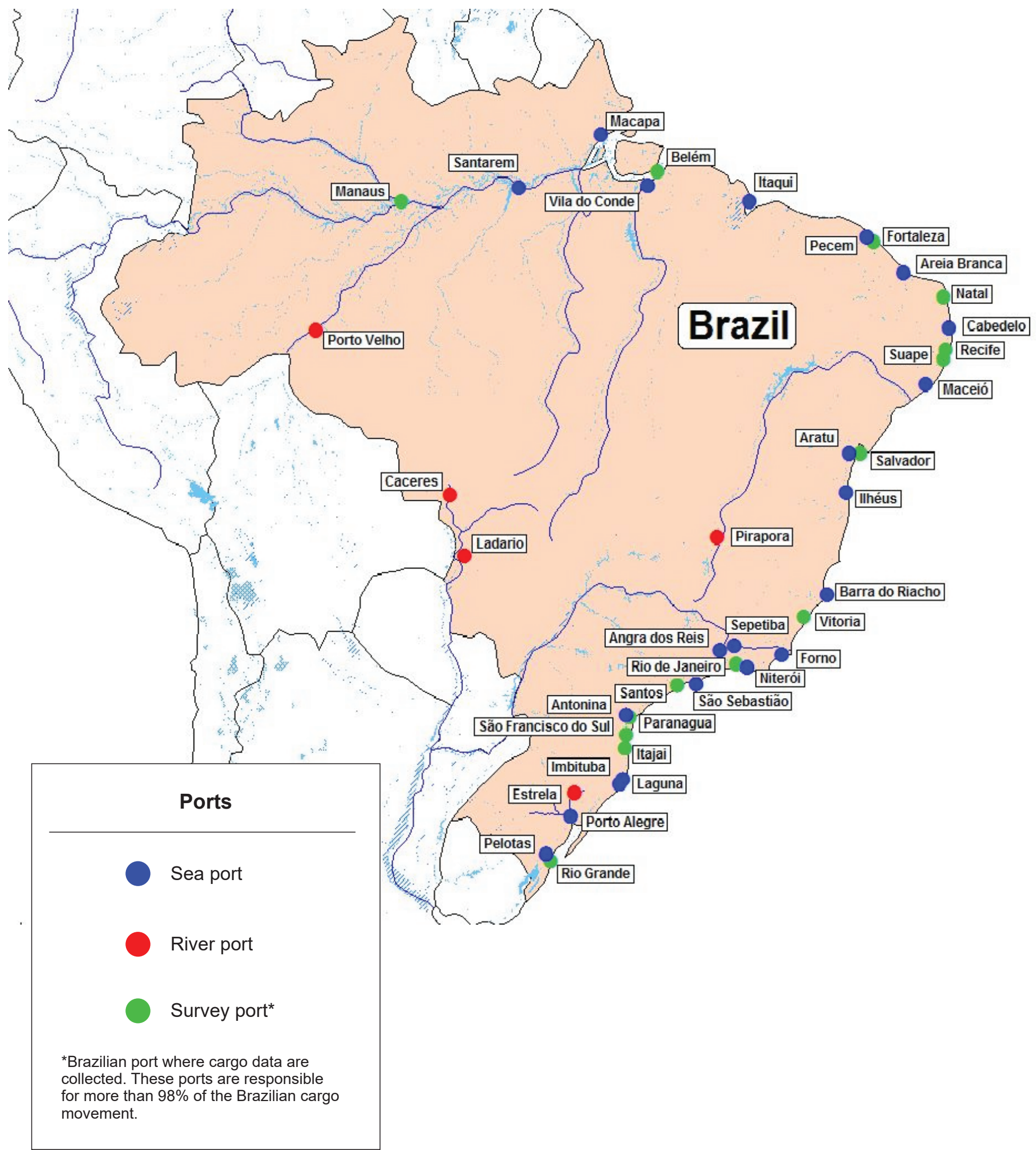

Sources: Companhia Nacional de Abastecimento (CONAB) and Ministério dos Transportes, Brazil. 


\section{Major rivers of the Amazonian Basin}

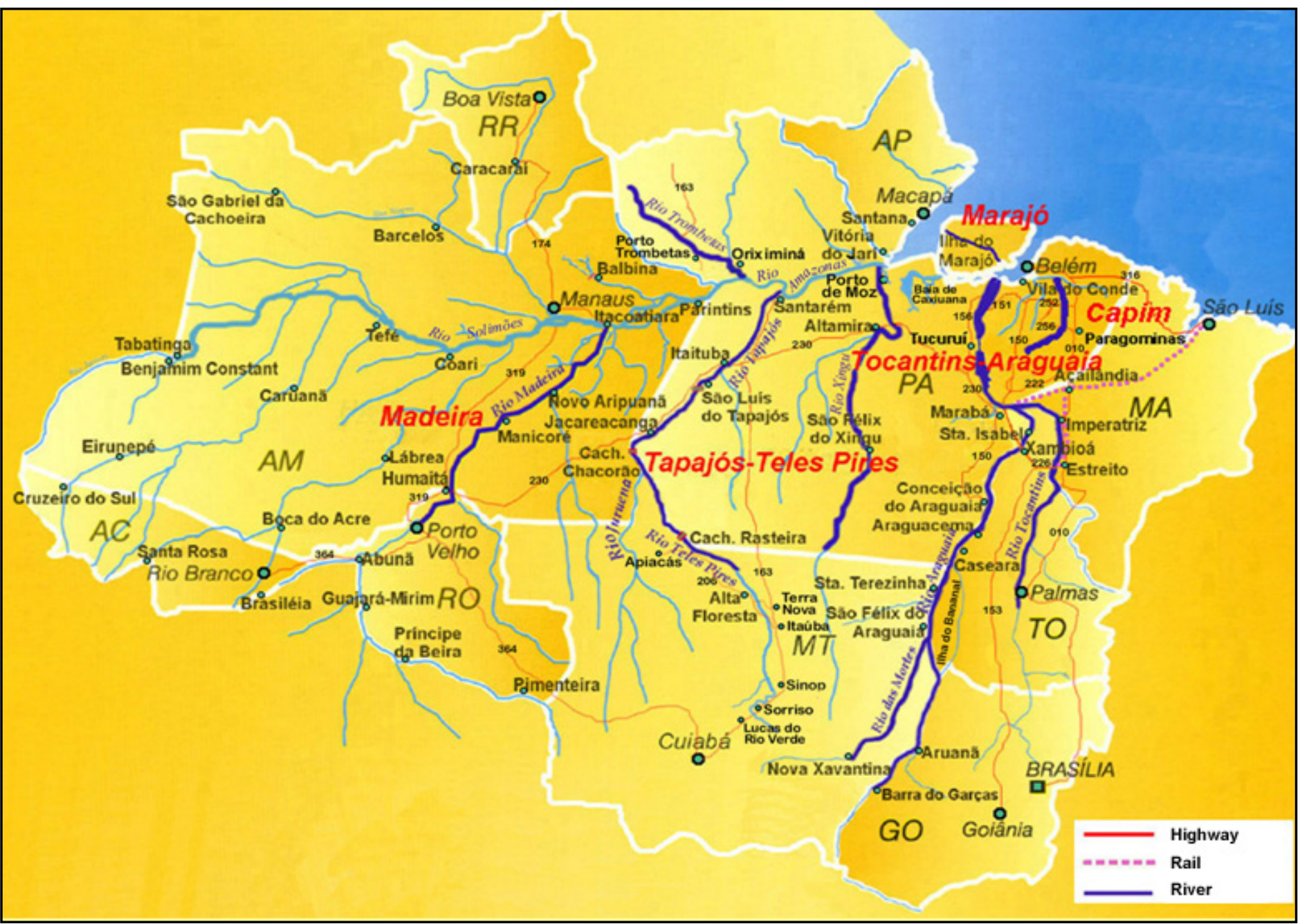

Source: National Agency for Waterway Transportation (ANTAQ).

Brazil has 39,146 miles of river-lake surface water and 27,340 miles of navigable rivers, but only 12,094 miles are commercially navigated.

\section{Brazil waterway system}

\begin{tabular}{|l|c|}
\hline \multicolumn{1}{|c|}{ Extension } & Miles \\
\hline River-lake surface water & 39,146 \\
\hline National river network & 27,340 \\
\hline Naturally navigable waterways & $25,970(100 \%)$ \\
\hline Commercial navigations & $12,094(47 \%)$ \\
\hline
\end{tabular}

Sources: Confederação Nacional do Transporte (CNT 2019) and National Agency for Waterway Transporation (ANTAQ 2016). 


\section{Brazilian port installations}

The Port of Manaus access channel is $1,640 \mathrm{ft}$ wide and $114.8 \mathrm{ft}$ deep. Porto Velho's access channel depth varies from 8.2 to $57.4 \mathrm{ft}$. The Port of Santarém's access channel is 5,904 ft wide and $49.2 \mathrm{ft}$ deep.

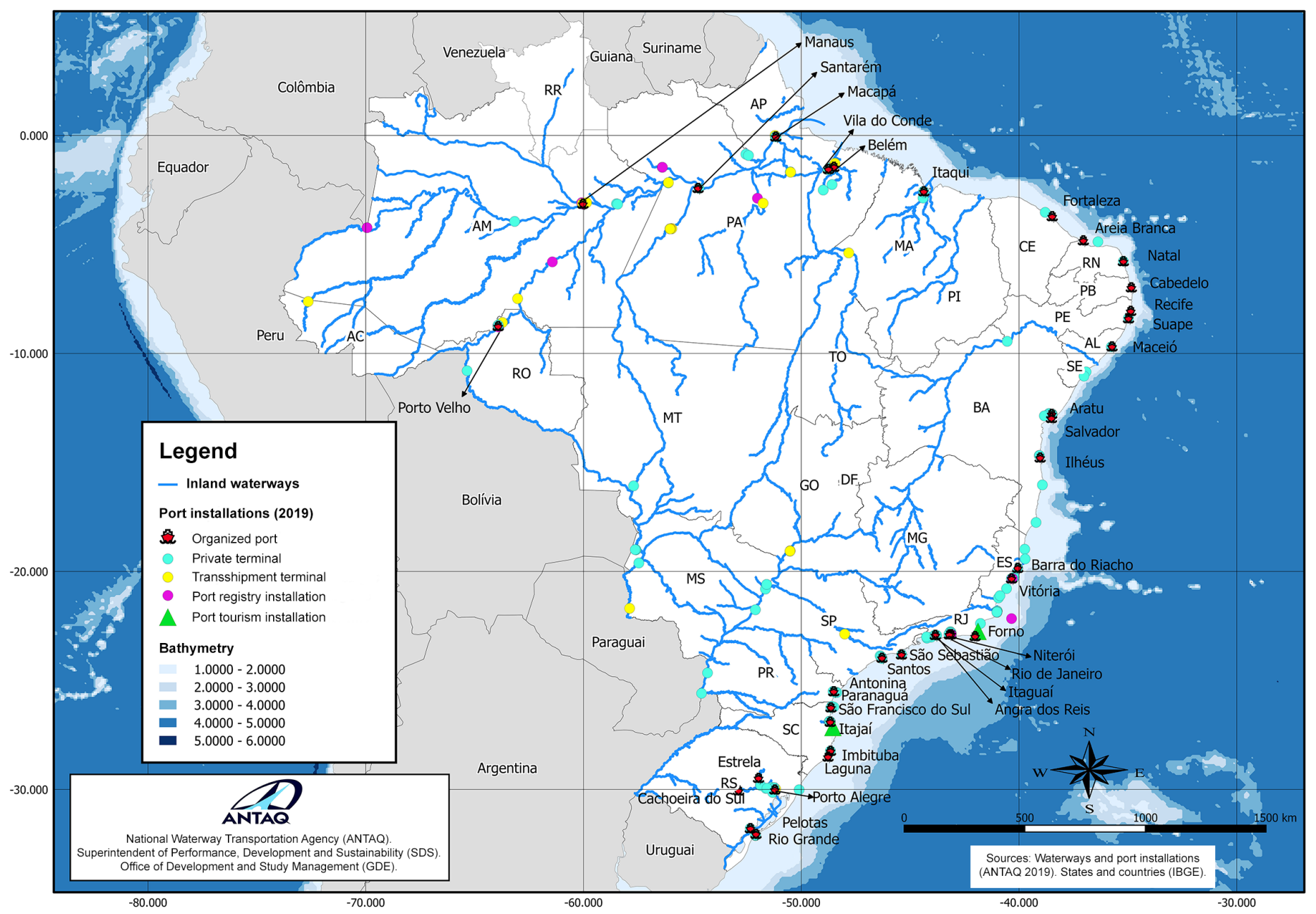

Sources: Agência Nacional de Transportes Aquaviários (ANTAQ). 


\section{Brazilian river basins}

Brazil's river system comprises eight basins: Amazônica, Northeast, Tocantins Araguaia, São Francisco, East, Tietê-Paraná, Paraguay, and South. The Amazônica and Paraguay Basin account for 72 percent of the total area of the Brazilian basins. The Paraguay Basin serves Argentina, Brazil, Bolivia, Paraguay, and Uruguay. Its navigable portion is comparable with the Mississippi River in the United States and the Rhine River in Europe.

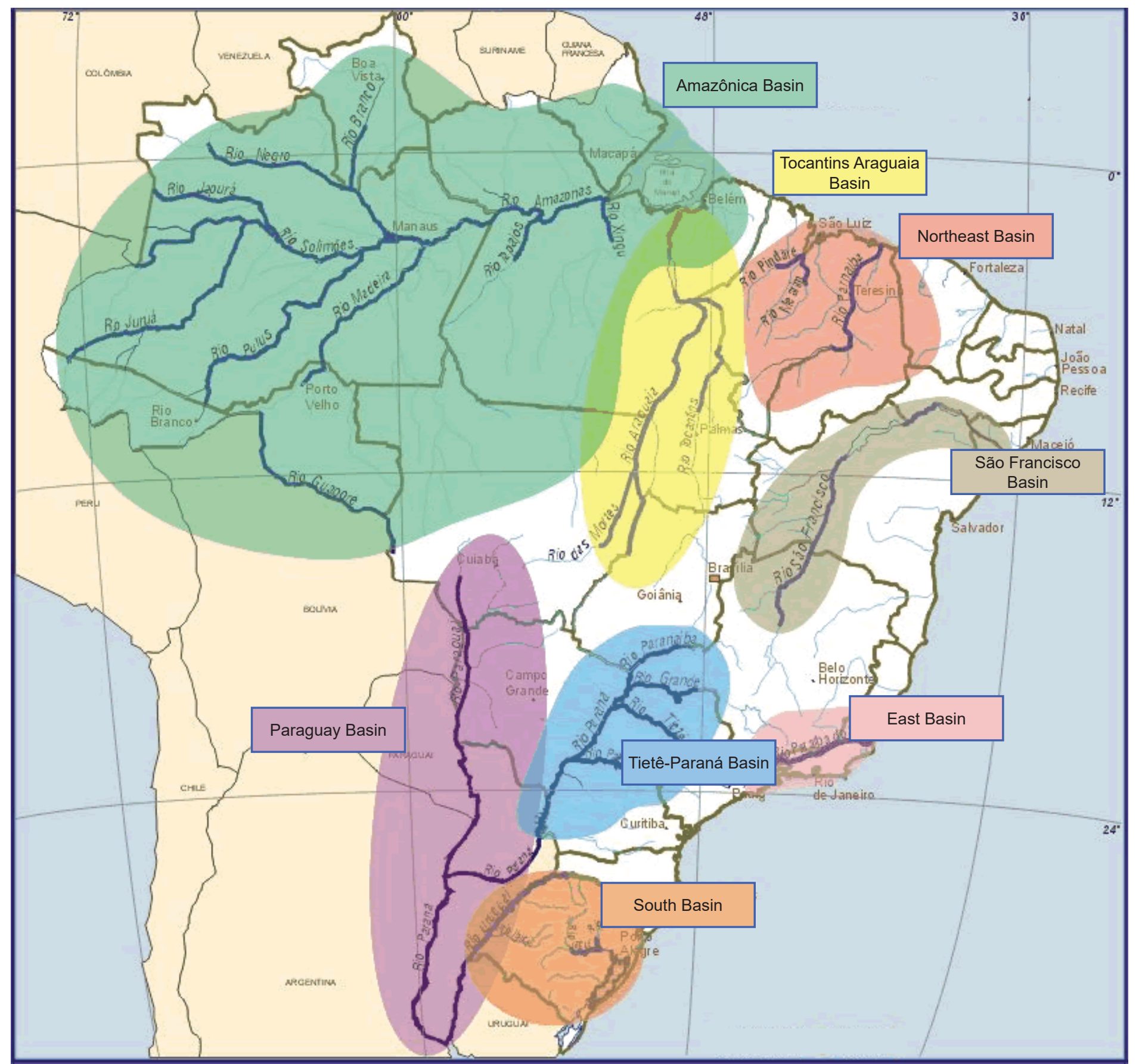

Source: Ministério dos Transportes, Brazil. 


\section{Brazilian commercial inland waterways}

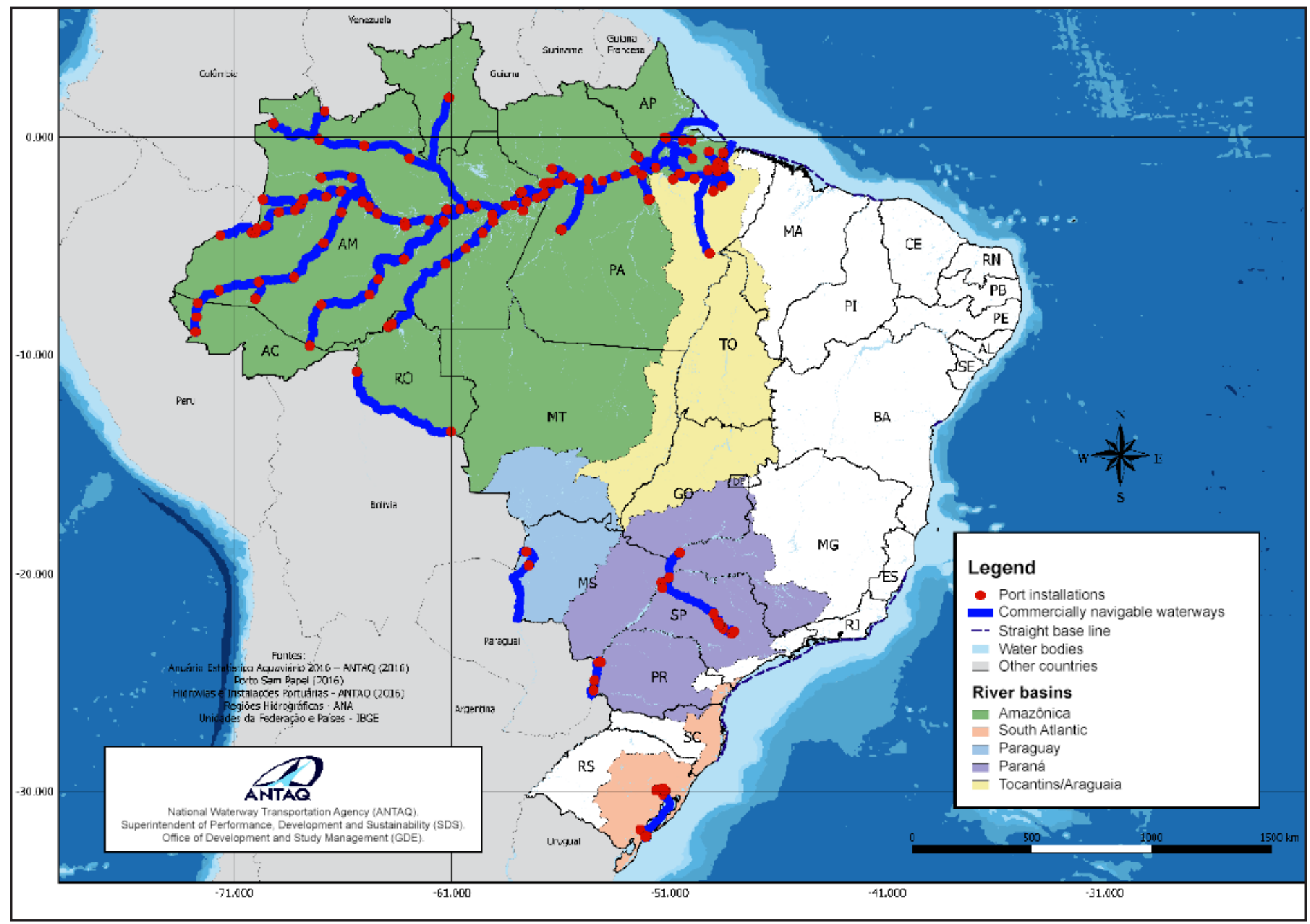

Source: Agência Nacional de Transportes Aquavárious. 


\section{Major river export routes}

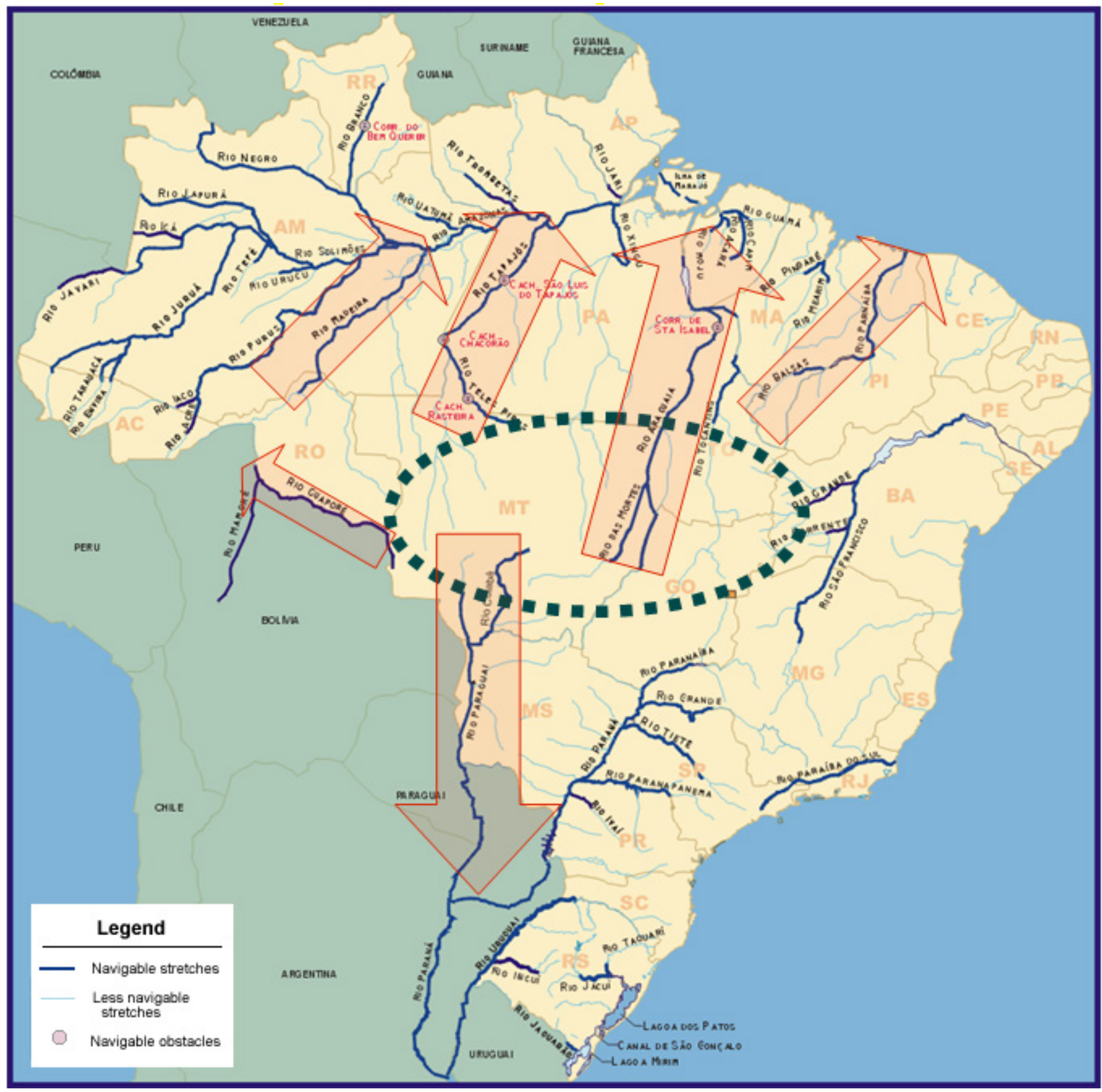

Source: National Agency for Waterway Transportation (ANTAQ). 
Major Brazilian highways

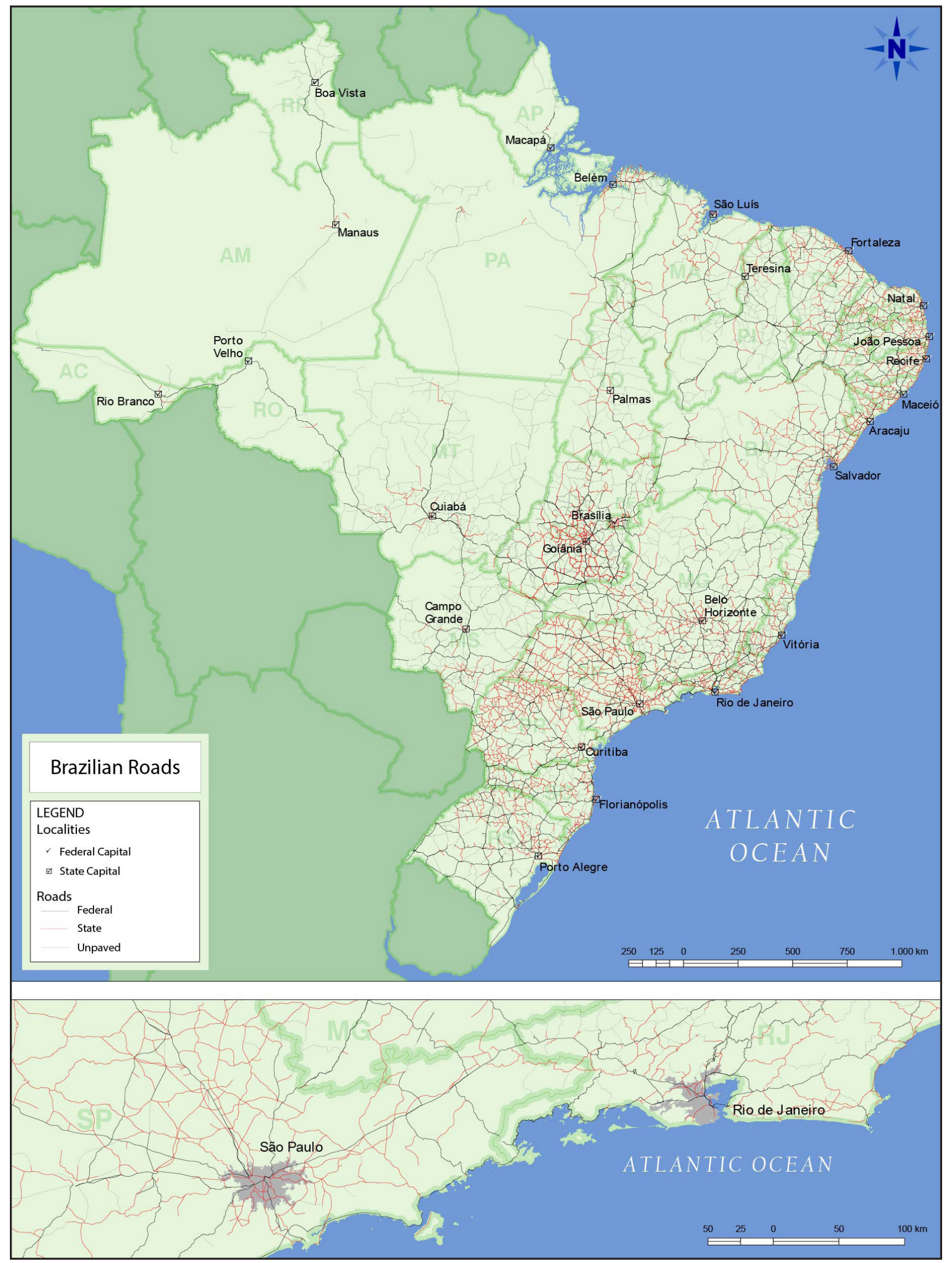

Source: Confederação Nacional do Transporte. 
The Brazilian highway system extends 968,863 miles (1,562,682 kilometers), with nearly 14 percent paved. The U.S. highway system consists of 4,160,800 miles $(6,696,142$ kilometers), with 68 percent paved.

\section{Brazil highway system, 2019}

\begin{tabular}{|l|c|c|c|}
\hline & Miles & \% Paved & \% Unpaved \\
\hline Federal & 46,961 & 86 & 14 \\
\hline State and county & 921,902 & 10 & 90 \\
\hline Total (federal + state and county) & $\mathbf{9 6 8 , 8 6 3}$ & & \\
\hline All roads & & $\mathbf{1 4}$ & $\mathbf{8 6}$ \\
\hline
\end{tabular}

Source: Confederação Nacional do Transporte (CNT).

U.S. highway system, 2018

\begin{tabular}{|l|c|c|c|}
\hline & Extension $^{1}$ (in miles) & \% Paved & \% Unpaved $^{2}$ \\
\hline Rural & $2,844,126$ & 58 & 42 \\
\hline Urban & $1,316,675$ & 96 & 4 \\
\hline Total & $\mathbf{4 , 1 6 0 , 8 0 0}$ & $\mathbf{6 8}$ & $\mathbf{3 2}$ \\
\hline
\end{tabular}

${ }^{1}$ Includes the 50 States, Puerto Rico (data may be incomplete), and the District of Columbia. Some differences from other tables may be noted because these are estimated from sample and summary data; some States may have missing/incomplete data.

2Paved includes the following categories: Bituminous (bituminous asphalt-concrete (AC) overlaid on existing AC pavement); Concrete (jointed plain concrete pavement (JPCP), jointed reinforced concrete pavement (JRCP), continuously reinforced concrete pavement (CRCP); unbonded jointed concrete overlaid on PCC pavement, bonded PCC overlaid on PCC pavement, other (includes "whitetopping")); and Composite (AC overlaid on jointed concrete pavement, AC (bituminous overlaid on existing CRCP).

Source: Highway Statistics 2018. U.S. Department of Transportation, Federal Highway Administration, Highway Statistics (Washington, DC: Annual Issues). 


\section{Brazilian highways}

The 2019 Confederação Nacional do Transporte (CNT) survey of the overall highway conditions in Brazil shows that 41 percent of the roads ranged from good to excellent in 2019 (compared to 43 percent in 2018). Still, 59 percent ranged from acceptable to very bad. The survey also shows that 49 percent of the paved roads were in good to excellent condition; 48.1 percent of traffic road signs had problems; and 85.4 percent of the paved roads had only two lanes. The survey sample of paved roads increased 1.6 percent, from 66,440 miles in 2018 to 67,495 miles in 2019.

\section{Brazilian highway conditions, 2017-19}

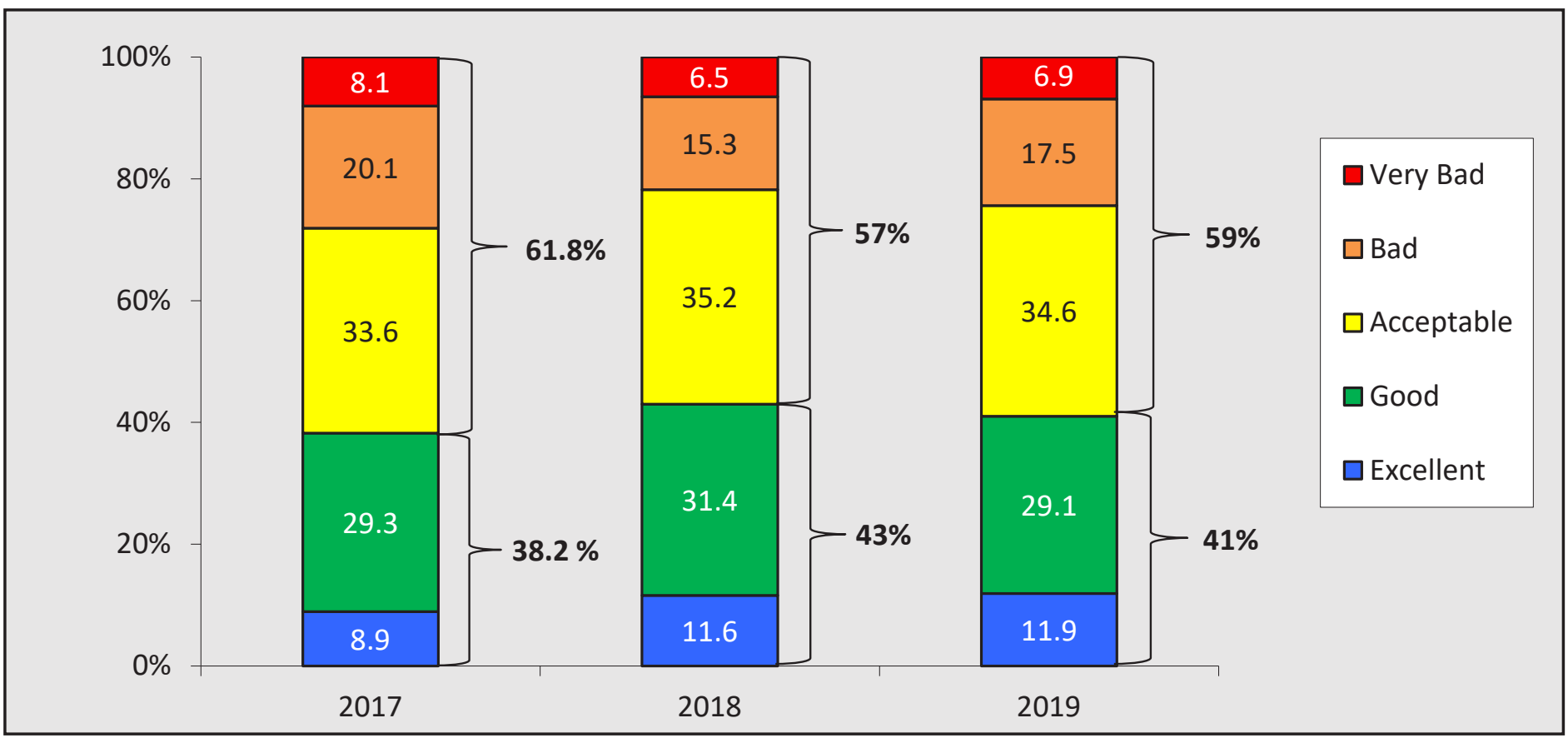

Source: Confederação Nacional do Transporte (CNT).

\section{Brazilian paved highway conditions, 2017-19}

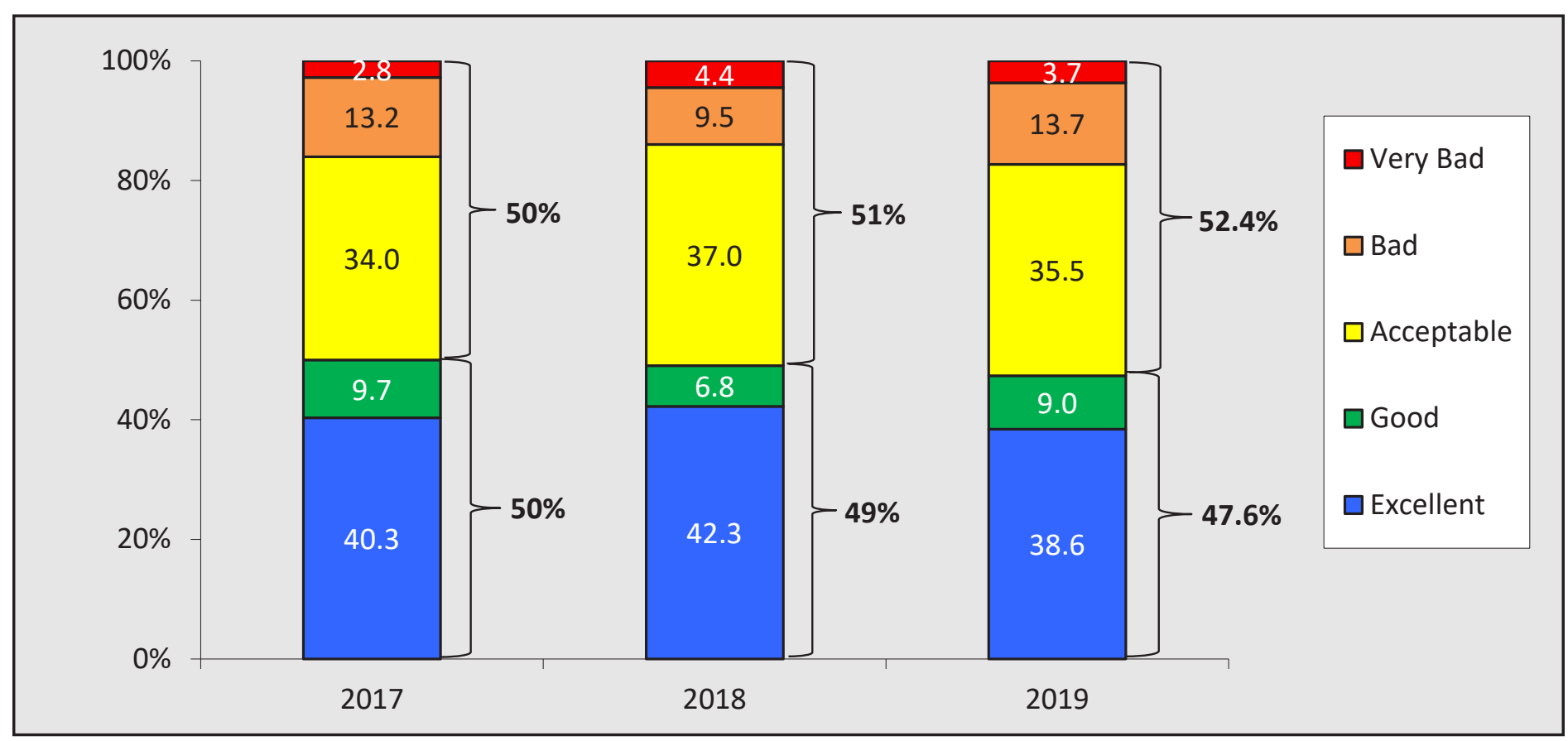

Source: Confederação Nacional do Transporte (CNT). 
Brazilian road sign conditions, 2017-19

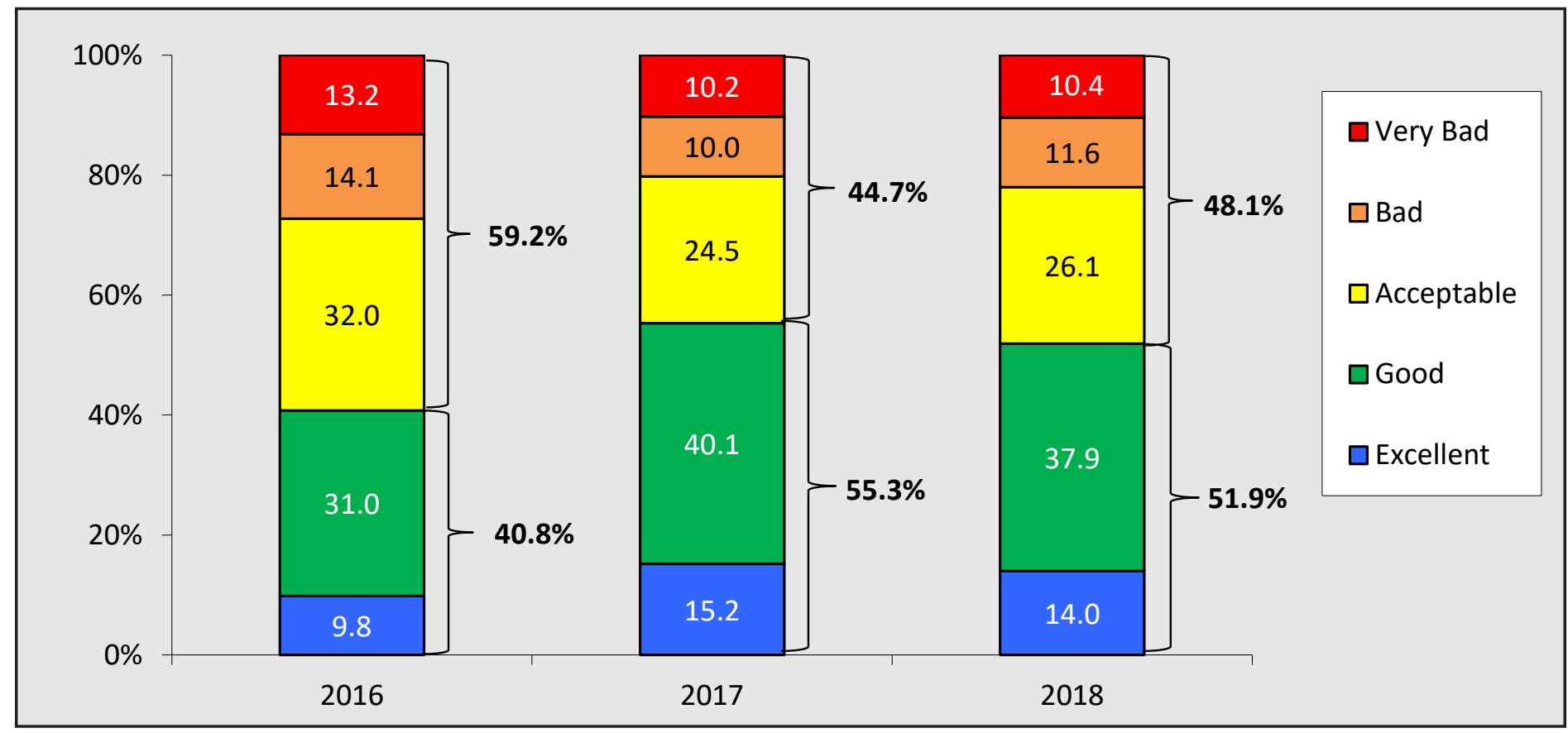

Source: Confederação Nacional do Transporte (CNT). 


\section{Brazilian railway expansion: ongoing projects}

The Brazilian railroad system consists of 12 railroads, with an extension of 18,943 miles, mostly concentrated in the South, Southeast, and Northeast.

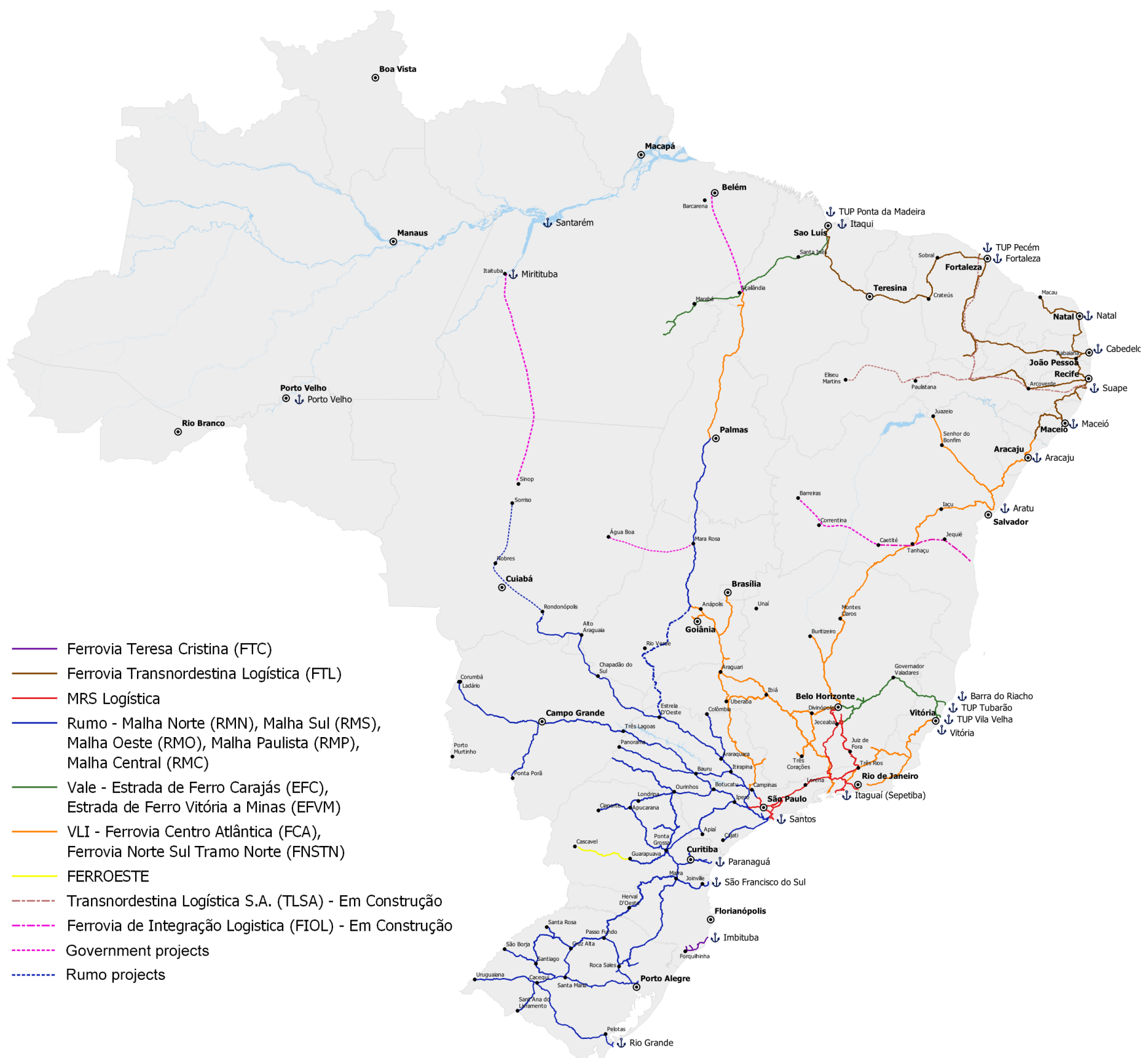

Source: Agência Nacional de Transportes Terrestres (ANTT). 


\section{Brazilian rail system: gauge sizes}

The gauge system (distance between two rails) varies by region, creating difficulties in integrating the system in regions like North America, which uses a standard gauge. There are three types of gauges: metric (39"), broad (63"), and mixed (39" - 63"). The metric gauge accounts for 76 percent of total Brazilian rail miles and predominates in the Southern region. The broad gauge accounts for 22 percent of total railroads and prevails in the Southeast region, leaving about 2 percent as mixed gauge.

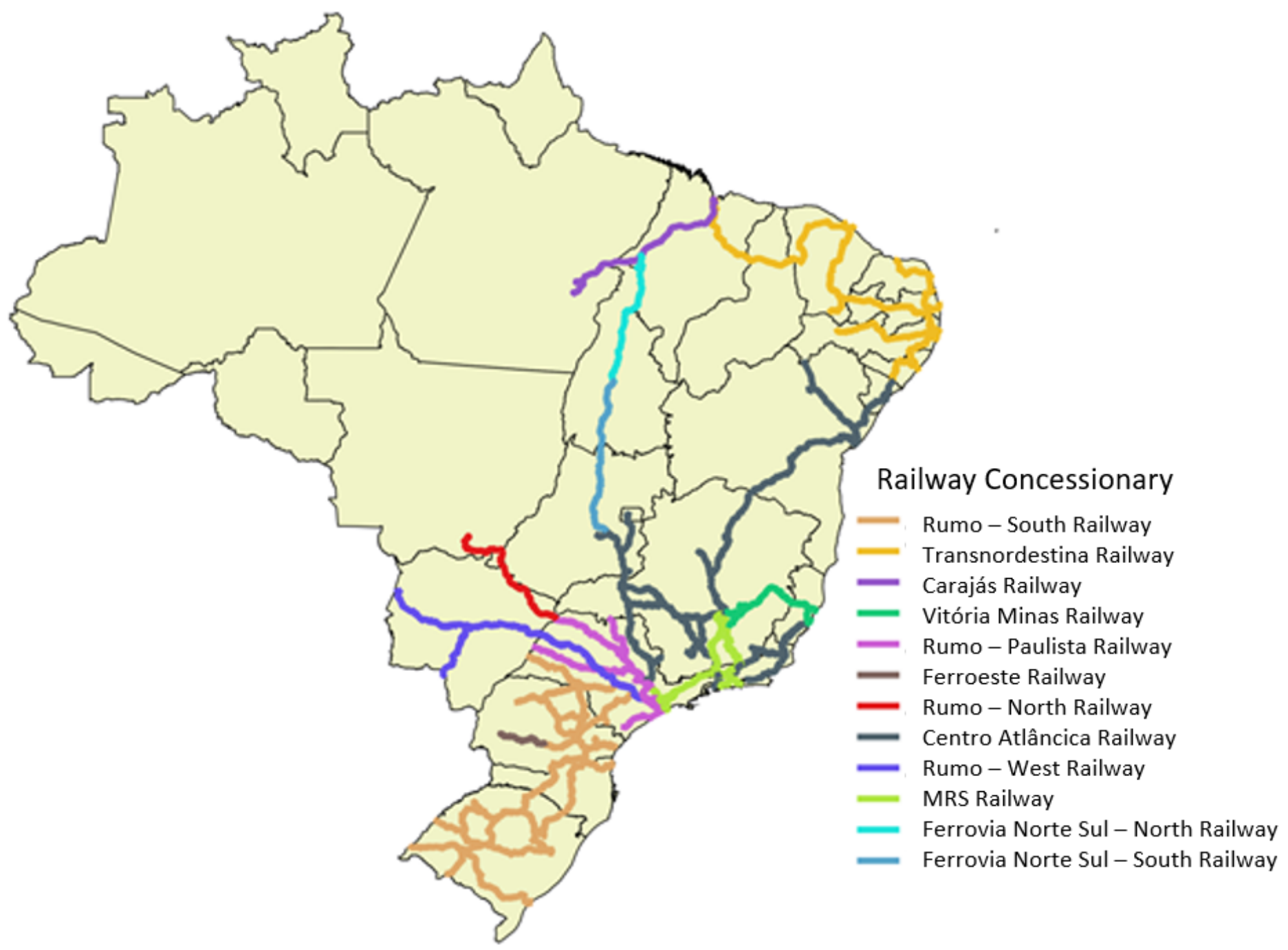

Source: Grupo de Pesquisa e Extensão em Logística Agroindustrial (ESALQ-LOG)/University of São Paulo, Brazil, based on data from the Agência Nacional de Transportes Terrestres (ANTT) 2018. 


\section{REFERENCE MATERIAL}

\section{Quarterly costs of transporting U.S. soybeans to Hamburg, Germany, via U.S. Gulf, 2019}

\begin{tabular}{|c|c|c|c|c|c|}
\hline & \multicolumn{5}{|c|}{ Minneapolis, Minnesota (US\$/mt) } \\
\hline & $\begin{array}{c}2019 \\
1 \text { st qtr }\end{array}$ & $\begin{array}{c}2019 \\
\text { 2nd qtr }\end{array}$ & $\begin{array}{c}2019 \\
3 r d \text { qtr }\end{array}$ & $\begin{array}{c}2019 \\
\text { 4th qtr }\end{array}$ & $\begin{array}{c}2019 \\
\text { Average }\end{array}$ \\
\hline Truck & 8.78 & 10.98 & 9.18 & 11.46 & 10.10 \\
\hline Rail $^{1}$ & 47.98 & 47.93 & - & - & 47.96 \\
\hline Barge $^{2}$ & 16.98 & 13.06 & 31.39 & 26.54 & 21.99 \\
\hline Ocean $^{3}$ & 16.73 & 16.62 & 20.21 & 19.02 & 18.15 \\
\hline Total transportation & 90.47 & 88.59 & 60.78 & 57.02 & 74.22 \\
\hline Farm price ${ }^{4}$ & 310.24 & 298.97 & 303.87 & 309.50 & 305.65 \\
\hline Landed cost ${ }^{5}$ & 400.71 & 387.56 & 364.65 & 366.52 & 379.86 \\
\hline \multirow[t]{3}{*}{ Transport $\%$ of landed cost } & 22.6 & 22.9 & 16.7 & 15.6 & 19.4 \\
\hline & \multicolumn{5}{|c|}{ Davenport, Iowa (US\$/mt) } \\
\hline & $\begin{array}{c}2019 \\
1 \text { st qtr }\end{array}$ & $\begin{array}{c}2019 \\
\text { 2nd qtr }\end{array}$ & $\begin{array}{c}2019 \\
\text { 3rd qtr }\end{array}$ & $\begin{array}{c}2019 \\
4 \text { th qtr }\end{array}$ & $\begin{array}{c}2019 \\
\text { Average }\end{array}$ \\
\hline Truck & 8.78 & 10.98 & 9.18 & 11.46 & 10.10 \\
\hline Rail $^{1}$ & 32.13 & 32.11 & - & - & 32.13 \\
\hline Barge $^{2}$ & 16.98 & 13.06 & 28.74 & 22.93 & 20.43 \\
\hline Ocean ${ }^{3}$ & 16.73 & 16.62 & 20.21 & 19.02 & 18.15 \\
\hline Total transportation & 74.62 & 72.77 & 58.13 & 53.41 & 64.73 \\
\hline Farm price $^{4}$ & 311.59 & 299.09 & 303.75 & 314.65 & 307.27 \\
\hline Landed cost $^{5}$ & 386.21 & 371.86 & 361.88 & 368.06 & 372.00 \\
\hline Transport \% of landed cost & 19.3 & 19.6 & 16.1 & 14.5 & 17.4 \\
\hline
\end{tabular}

${ }^{1}$ Rail rates include fuel surcharges, but do not include the cost of purchasing empty rail cars in the secondary rail markets, which could exceed the rail tariff rate plus fuel surcharge shown in the table.

${ }^{2}$ The Mississippi River closes from Minneapolis to just north of St. Louis during mid-December to late March.

${ }^{3}$ Source for the U.S. ocean freight rates: O'Neil Commodity Consulting.

${ }^{4}$ Source for the U.S. farm prices: USDA, National Agricultural Statistics Service.

${ }^{5}$ Landed cost is transportation cost plus farm price.

Note: qtr. = quarter; $y r$. = year; $\mathrm{mt}=$ metric ton; total may not add exactly due to rounding.

Source: Compiled by the USDA, Agricultural Marketing Service. 
Quarterly costs of transporting U.S. soybeans to Shanghai, China, via U.S. Gulf, 2019

\begin{tabular}{|c|c|c|c|c|c|}
\hline & \multicolumn{5}{|c|}{ Minneapolis, Minnesota (US\$/mt) } \\
\hline & $\begin{array}{c}2019 \\
1 s t \text { qtr }\end{array}$ & $\begin{array}{c}2019 \\
\text { 2nd qtr }\end{array}$ & $\begin{array}{c}2019 \\
3 r d \text { qtr }\end{array}$ & $\begin{array}{c}2019 \\
4 \text { th qtr }\end{array}$ & $\begin{array}{c}2019 \\
\text { Average }\end{array}$ \\
\hline Truck & 8.78 & 10.98 & 9.18 & 11.46 & 10.10 \\
\hline Rail $^{1}$ & 47.98 & 47.93 & - & - & 47.96 \\
\hline Barge $^{2}$ & 16.98 & 13.06 & 31.39 & 26.54 & 21.99 \\
\hline Ocean $^{3}$ & 39.61 & 42.20 & 49.35 & 47.05 & 44.55 \\
\hline Total transportation & 113.35 & 114.17 & 89.92 & 85.05 & 100.62 \\
\hline Farm price $^{4}$ & 310.24 & 298.97 & 303.87 & 309.50 & 305.65 \\
\hline Landed cost $^{5}$ & 423.59 & 413.14 & 393.79 & 394.55 & 406.27 \\
\hline \multirow[t]{3}{*}{ Transport $\%$ of landed cost } & 26.8 & 27.6 & 22.8 & 21.6 & 24.7 \\
\hline & \multicolumn{5}{|c|}{ Davenport, Iowa (US\$/mt) } \\
\hline & $\begin{array}{c}2019 \\
1 \text { st qtr }\end{array}$ & $\begin{array}{c}2019 \\
\text { 2nd qtr }\end{array}$ & $\begin{array}{c}2019 \\
\text { 3rd qtr }\end{array}$ & $\begin{array}{c}2019 \\
4 \text { th qtr }\end{array}$ & $\begin{array}{c}2019 \\
\text { Average }\end{array}$ \\
\hline Truck & 8.78 & 10.98 & 9.18 & 11.46 & 10.10 \\
\hline Rail $^{1}$ & 32.12 & 32.11 & - & - & 32.12 \\
\hline Barge $^{2}$ & 16.98 & 13.06 & 28.74 & 22.93 & 20.43 \\
\hline Ocean $^{3}$ & 39.61 & 42.20 & 49.35 & 47.05 & 44.55 \\
\hline Total transportation & 97.49 & 98.35 & 87.27 & 81.44 & 91.14 \\
\hline Farm price ${ }^{4}$ & 311.59 & 299.09 & 303.75 & 314.65 & 307.27 \\
\hline Landed $\operatorname{cost}^{5}$ & 409.08 & 397.44 & 391.02 & 396.09 & 398.41 \\
\hline Transport \% of landed cost & 23.8 & 24.7 & 22.3 & 20.6 & 22.9 \\
\hline
\end{tabular}

${ }^{1}$ Rail rates include fuel surcharges, but do not include the cost of purchasing empty rail cars in the secondary rail markets, which could exceed the rail tariff rate plus fuel surcharge shown in the table.

${ }^{2}$ The Mississippi River closes from Minneapolis to just north of St. Louis during mid-December to late March.

${ }^{3}$ Source for the U.S. ocean freight rates: O'Neil Commodity Consulting.

${ }^{4}$ Source for the U.S. farm prices: USDA, National Agricultural Statistics Service.

${ }^{5}$ Landed cost is transportation cost plus farm price.

Note: qtr. = quarter; $y r$. = year; $\mathrm{mt}=$ metric ton; total may not add exactly due to rounding.

Source: Compiled by the USDA, Agricultural Marketing Service. 
Quarterly costs of transporting U.S. soybeans to Shanghai, China, via PNW, 2019

\begin{tabular}{|c|c|c|c|c|c|}
\hline & \multicolumn{5}{|c|}{ Fargo, North Dakota (US\$/mt) } \\
\hline & $\begin{array}{c}2019 \\
1 \text { st qtr }\end{array}$ & $\begin{array}{c}2019 \\
\text { 2nd qtr }\end{array}$ & $\begin{array}{c}2019 \\
3 r d \text { qtr }\end{array}$ & $\begin{array}{c}2019 \\
4 \text { th } q \operatorname{tr}\end{array}$ & $\begin{array}{c}2019 \\
\text { Average }\end{array}$ \\
\hline Truck & 8.78 & 10.98 & 9.18 & 11.46 & 10.10 \\
\hline Rail $^{1}$ & 56.11 & 56.11 & 56.11 & 57.10 & 56.36 \\
\hline Ocean ${ }^{2}$ & 22.44 & 22.93 & 27.28 & 25.71 & 24.59 \\
\hline Total transportation & 87.33 & 90.02 & 92.57 & 94.27 & 91.05 \\
\hline Farm price ${ }^{3}$ & 290.28 & 277.90 & 281.33 & 293.09 & 285.65 \\
\hline Landed cost ${ }^{4}$ & 377.61 & 367.92 & 373.90 & 387.36 & 376.70 \\
\hline \multirow[t]{3}{*}{ Transport $\%$ of landed cost } & 23.1 & 24.5 & 24.8 & 24.3 & 24.2 \\
\hline & \multicolumn{5}{|c|}{ Sioux Falls, South Dakota (US\$/mt) } \\
\hline & $\begin{array}{c}2019 \\
1 \text { st qtr }\end{array}$ & $\begin{array}{c}2019 \\
\text { 2nd qtr }\end{array}$ & $\begin{array}{c}2019 \\
3 r d \text { qtr }\end{array}$ & $\begin{array}{c}2019 \\
4 \text { th qtr }\end{array}$ & $\begin{array}{c}2019 \\
\text { Average }\end{array}$ \\
\hline Truck & 8.78 & 10.98 & 9.18 & 11.46 & 10.10 \\
\hline Rail $^{1}$ & 57.10 & 57.10 & 57.10 & 58.09 & 57.35 \\
\hline Ocean ${ }^{2}$ & 22.44 & 22.93 & 27.28 & 25.71 & 24.59 \\
\hline Total transportation & 88.32 & 91.01 & 93.56 & 95.26 & 92.04 \\
\hline Farm price ${ }^{3}$ & 296.64 & 284.15 & 288.44 & 306.69 & 293.98 \\
\hline Landed cost ${ }^{4}$ & 384.96 & 375.16 & 382.00 & 401.95 & 386.02 \\
\hline Transport \% of landed cost & 22.9 & 24.3 & 24.5 & 23.7 & 23.8 \\
\hline
\end{tabular}

${ }^{1}$ Rail rates include fuel surcharges, but do not include the cost of purchasing empty rail cars in the secondary rail markets, which could exceed the rail tariff rate plus fuel surcharge shown in the table.

${ }^{2}$ Source for the U.S. ocean freight rates: O'Neil Commodity Consulting.

${ }^{3}$ Source for the U.S. farm prices: USDA, National Agricultural Statistics Service.

${ }^{4}$ Landed cost is transportation cost plus farm price.

Note: qtr. = quarter; $y r$. = year; $\mathrm{mt}=$ metric ton; total may not add exactly due to rounding.

Source: Compiled by the USDA, Agricultural Marketing Service. 
Average quarterly exchange rate, 2013-19

\begin{tabular}{|c|c|}
\hline Quarter & Real per US\$ \\
\hline $1 \mathrm{st}$ & 1.9977 \\
\hline 2nd & 2.0673 \\
\hline $3 r d$ & 2.2880 \\
\hline 4th & 2.2735 \\
\hline 2013 Average & 2.1566 \\
\hline $1 \mathrm{st}$ & 2.2735 \\
\hline 2nd & 2.2296 \\
\hline $3 \mathrm{rd}$ & 2.2745 \\
\hline 4th & 2.5437 \\
\hline 2014 Average & 2.3303 \\
\hline $1 \mathrm{st}$ & 2.8637 \\
\hline 2nd & 3.0722 \\
\hline $3 r d$ & 3.5480 \\
\hline 4th & 3.8426 \\
\hline 2015 Average & 3.3316 \\
\hline $1 \mathrm{st}$ & 3.8999 \\
\hline 2nd & 3.5076 \\
\hline $3 r d$ & 3.2912 \\
\hline 4th & 3.2953 \\
\hline 2016 Average & 3.4985 \\
\hline $1 \mathrm{st}$ & 3.1429 \\
\hline 2nd & 3.2137 \\
\hline $3 r d$ & 3.1639 \\
\hline 4th & 3.2506 \\
\hline 2017 Average & 3.1928 \\
\hline $1 \mathrm{st}$ & 3.2425 \\
\hline 2nd & 3.7732 \\
\hline $3 r d$ & 3.9505 \\
\hline 4th & 3.8084 \\
\hline 2018 Average & 3.6936 \\
\hline $1 \mathrm{st}$ & 3.7684 \\
\hline 2nd & 3.9221 \\
\hline $3 r d$ & 3.9736 \\
\hline 4th & 4.1144 \\
\hline 2019 Average & 3.9446 \\
\hline
\end{tabular}

Source:Banco Central do Brasil 
Selected quarterly Brazilian farm prices, 2016-19

(US $\$ /$ metric ton)

\begin{tabular}{|c|c|c|c|c|c|c|c|}
\hline Quarter & $\begin{array}{l}\text { Rio Grande } \\
\text { do Sul }\end{array}$ & $\begin{array}{l}\text { Mato } \\
\text { Grosso }\end{array}$ & Goiás & Paraná & Piauí & Pará & Maranhão \\
\hline $1 s t$ & 308.73 & 268.28 & 278.59 & 298.84 & 281.05 & 264.90 & 310.69 \\
\hline 2nd & 358.57 & 347.59 & 337.86 & 353.78 & 342.05 & 329.13 & 378.45 \\
\hline $3 r d$ & 373.12 & 367.25 & 359.07 & 362.80 & 378.98 & 384.42 & 447.42 \\
\hline 4th & 352.69 & 344.51 & 341.08 & 347.53 & 377.05 & 355.82 & 370.99 \\
\hline 2016 Avg & 348.28 & 331.91 & 329.15 & 340.74 & 344.78 & 333.57 & 376.89 \\
\hline $1 s t$ & 347.99 & 314.10 & 332.40 & 344.08 & 210.49 & 362.30 & 356.01 \\
\hline 2nd & 302.06 & 275.60 & 281.73 & 304.50 & 304.16 & 313.78 & 327.17 \\
\hline $3 r d$ & 317.17 & 288.62 & 291.58 & 313.53 & 306.34 & 324.84 & 340.58 \\
\hline 4th & 321.99 & 296.10 & 302.26 & 324.03 & 311.19 & 339.05 & 349.81 \\
\hline Quarter & $\begin{array}{c}\text { Rio Grande } \\
\text { do Sul }\end{array}$ & $\begin{array}{c}\text { Mato } \\
\text { Grosso }\end{array}$ & Goiás & Paraná & Piauí & Pará & Maranhão \\
\hline 2017 Avg & 322.30 & 293.60 & 301.99 & 321.54 & 283.05 & 334.99 & 343.39 \\
\hline $1 s t$ & 334.43 & 305.85 & 318.87 & 338.61 & 321.69 & 344.84 & 357.97 \\
\hline 2nd & 343.90 & 323.46 & 313.65 & 347.41 & 320.70 & 343.23 & 342.78 \\
\hline $3 r d$ & 326.13 & 301.39 & 302.33 & 330.85 & 290.62 & 323.15 & 305.07 \\
\hline 4th & 328.39 & 293.43 & 314.40 & 319.39 & 292.04 & 344.82 & 326.30 \\
\hline 2018 Avg & 333.21 & 306.03 & 312.31 & 334.06 & 306.26 & 339.01 & 333.03 \\
\hline $1 s t$ & 308.52 & 275.38 & 296.01 & 304.16 & 292.96 & 317.97 & 298.43 \\
\hline 2nd & 294.72 & 271.70 & 281.40 & 292.33 & 285.28 & 294.15 & 278.70 \\
\hline $3 r d$ & 304.20 & 286.87 & 286.67 & 300.23 & 288.35 & 303.50 & 300.20 \\
\hline 4th & 314.81 & 307.47 & 301.77 & 313.72 & 316.88 & 316.00 & 310.87 \\
\hline 2019 Avg & 305.56 & 285.35 & 291.46 & 302.61 & 295.87 & 307.90 & 297.05 \\
\hline
\end{tabular}

Source: Companhia Nacional de Abastecimento (CONAB) www.conab.gov.br 


\section{PHOTO CREDITS}

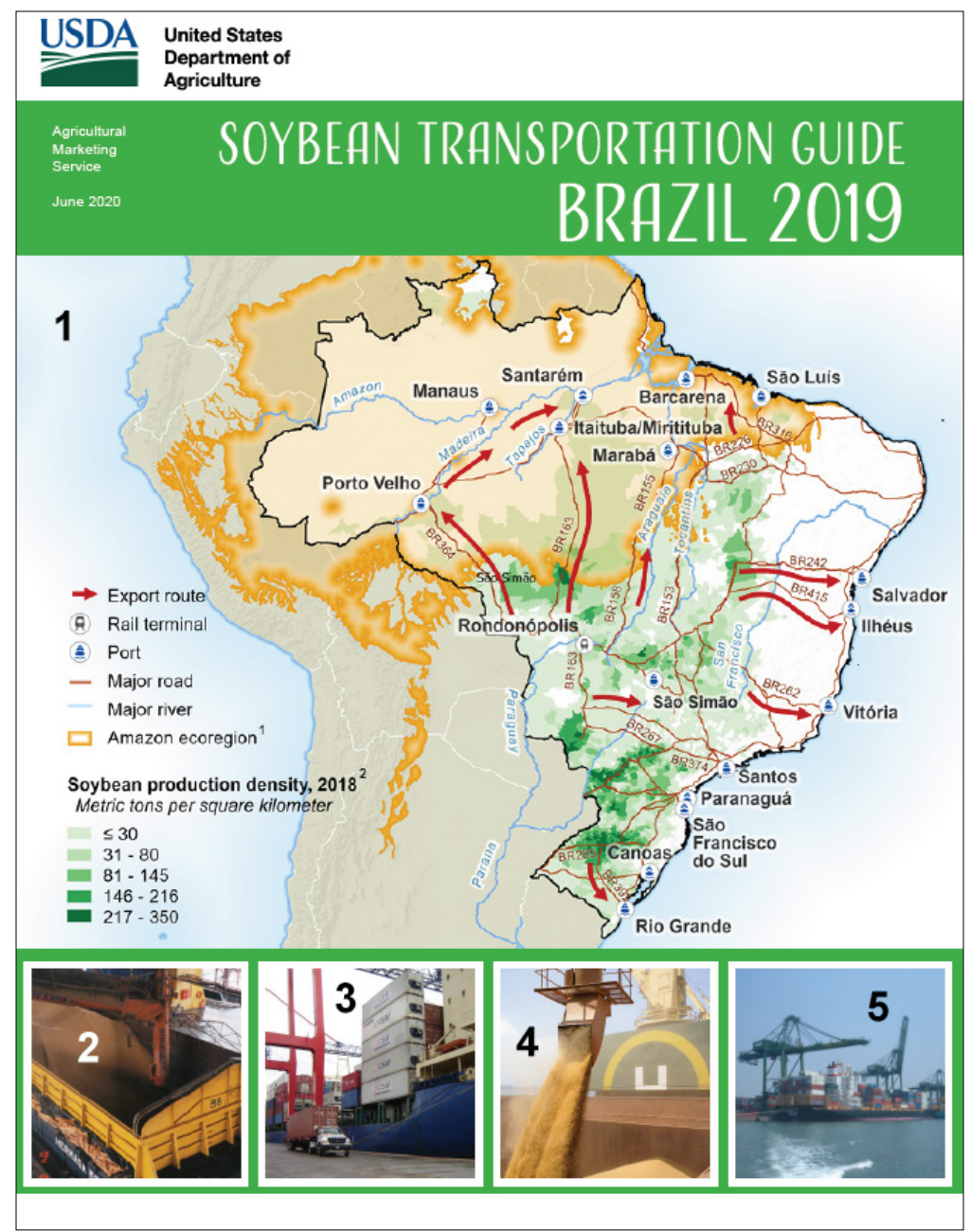

Photo credits:

1) USDA/Agricultural Marketing Service (AMS) and USDA/Foreign Agricultural Service (FAS).

2) USDA

3) ESALQ-log

4) The Assesoria de Comunicação dos Portos de Paranaguá e Antonina (ASSCOM-APPA)

5) ESALQ-log 